\title{
WestVirginiaUniversity
}

THE RESEARCH REPOSITORY @ WVU

Graduate Theses, Dissertations, and Problem Reports

2014

\section{The Political Economy of Pork-Barrel Spending}

J. Zachary Klingensmith

Follow this and additional works at: https://researchrepository.wvu.edu/etd

\section{Recommended Citation}

Klingensmith, J. Zachary, "The Political Economy of Pork-Barrel Spending" (2014). Graduate Theses, Dissertations, and Problem Reports. 5991.

https://researchrepository.wvu.edu/etd/5991

This Dissertation is protected by copyright and/or related rights. It has been brought to you by the The Research Repository @ WVU with permission from the rights-holder(s). You are free to use this Dissertation in any way that is permitted by the copyright and related rights legislation that applies to your use. For other uses you must obtain permission from the rights-holder(s) directly, unless additional rights are indicated by a Creative Commons license in the record and/ or on the work itself. This Dissertation has been accepted for inclusion in WVU Graduate Theses, Dissertations, and Problem Reports collection by an authorized administrator of The Research Repository @ WVU.

For more information, please contact researchrepository@mail.wvu.edu. 


\title{
The Political Economy of Pork-Barrel Spending
}

\section{J. Zachary Klingensmith}

\author{
Dissertation Submitted \\ to the College of Business and Economics \\ at West Virginia University
}

In partial fulfillment of the requirements for the degree of

Doctor in Philosophy in

Economics

\author{
Roger Congleton, Ph.D, Chair \\ Brian Cushing, Ph.D. \\ Leslie Dunn, Ph.D. \\ Joshua Hall, Ph.D \\ Donald Lacombe, Ph.D. \\ Department of Economics \\ Morgantown, WV \\ 2014
}

Key words: Campaign fundraising; Electoral success; Employment; Political Economy; PorkBarrel Spending; Public Economics

Copyright 2014 J. Zachary Klingensmith 


\section{Abstract \\ The Political Economy of Pork-Barrel Spending J. Zachary Klingensmith}

This dissertation consists of five papers which examine the impact pork-barrel spending has on legislative decision-making. In chapter 1 , I introduce the theory behind pork-barrel spending, legislative coalitions and other similar topics. In chapter 2, I determine if pork-barrel spending has any impact on state employment levels. I use both a spatial and non-spatial modeling methodology to answer the question. Chapter 3 examines the relationship between the amount of pork-barrel spending appropriated by the Senator and the amount of money the Senator is able to fundraise. Chapter 4 integrates the results from chapter 3 to develop two-stage and three-stage models which estimate electoral success. The fifth and final chapter concludes the dissertation by using the results from the other chapters to determine whether or not pork-barrel spending suffers from the Tragedy of the Commons. 


\section{Acknowledgements}

First and foremost, I would like to thank my wife for all of the support she has given me over the past eight years. Even though we have both been stressed pursuing our doctorates, I know that our love and support for each other has had only a positive impact on our work.

I would also like to express sincere thanks to my family. Even though I have been in school for twenty-four years, your assistance has been unwavering. Without your support and the knowledge that you are supporting my decisions, I am not sure if I would have ever gotten to this point. I will finally have the desk I have been working towards since first grade.

Next, I would like to thank my advisor Dr. Roger Congleton. Even though you came at the start of my third year, I have learned a tremendous amount from you. You have helped me become a better researcher and writer and, most importantly, a better academic. I know that I will look back at my years at WVU very fondly because of you.

I would also like to thank my committee for all of the feedback, advice and support. Those on my committee include Dr. Brian Cushing, Dr. Leslie Dunn, Dr. Joshua Hall and Dr. Donald Lacombe. In addition to their work on my committee, each of my committee members has influenced my career both in and out of the classroom as well.

Finally, I would like to thank both my friends and past professors as well. Specifically, I would like to thank both Patrick Manzi and William McAndrew for all of their comradery and assistance during my time at WVU. I would also like to thank my professors, in both mathematics and economics, at Washington and Jefferson College as well as my teachers at Yough High School. 


\section{Table of Contents}

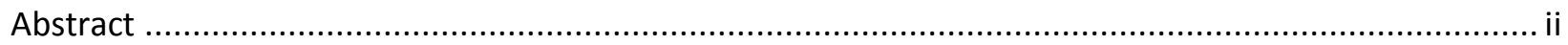

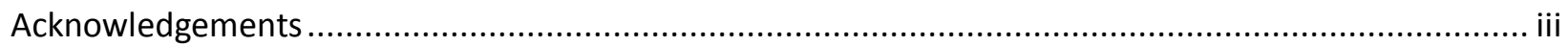

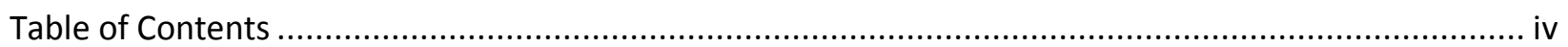

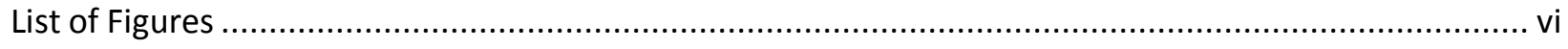

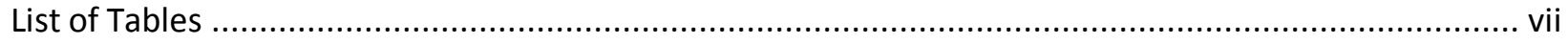

Chapter 1: The Institutions of Pork-Barrel Spending................................................................ 1

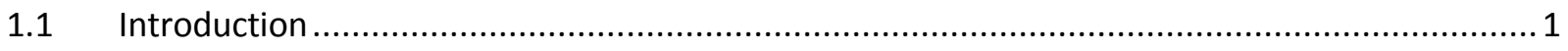

1.2 The Institutions of Earmark Legislation ............................................................................ 3

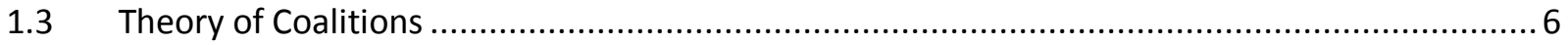

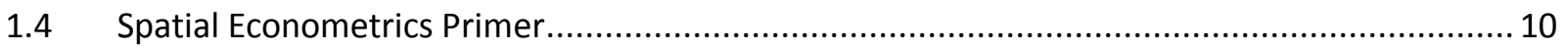

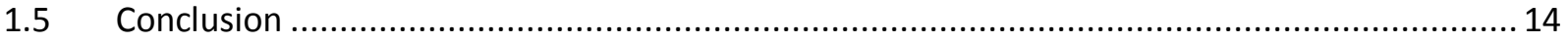

Chapter 2: Pork-Barrel Spending and State Employment Levels .................................................... 16

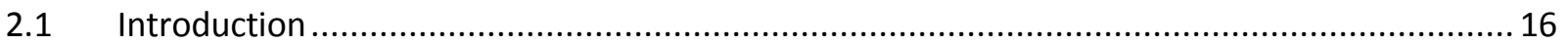

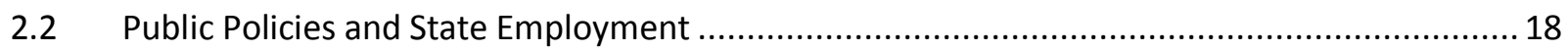

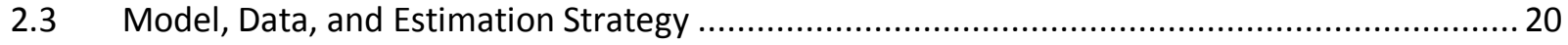

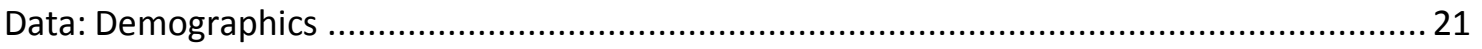

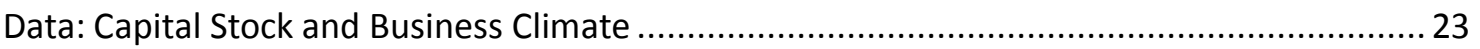

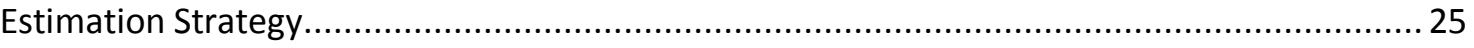

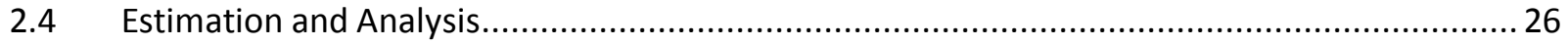

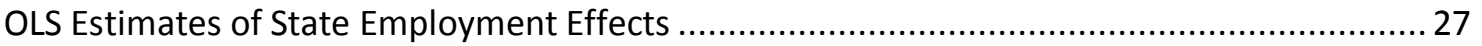

OLS Estimates of State Economic Growth Rate Effects ....................................................... 30

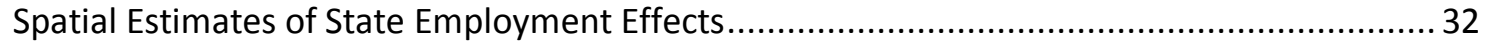

Spatial Estimates of State Economic Growth Rate Effects ................................................ 35

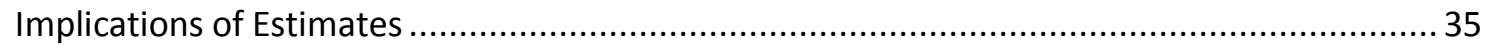

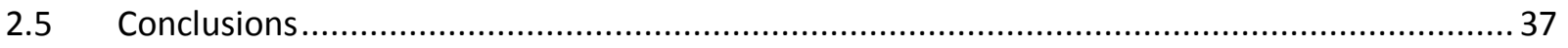

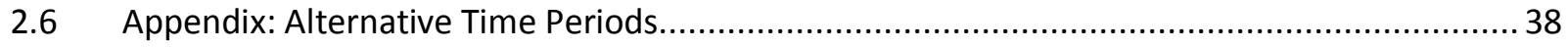

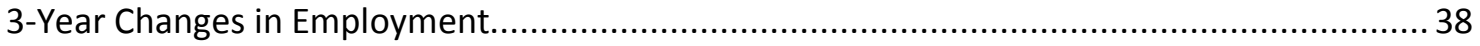

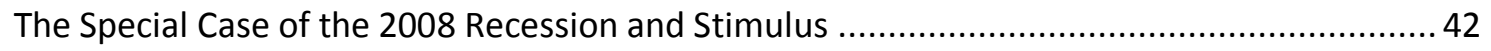

Chapter 3: The Impact of Pork-Barrel Spending on Incumbent Fundraising ...................................... 44

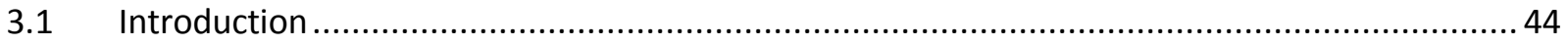

3.2 District Targeted Federal Spending and Reelection...................................................... 45 
3.3 The Fundraising Effects of Pork Are Understudied ................................................... 48

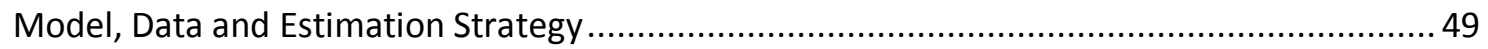

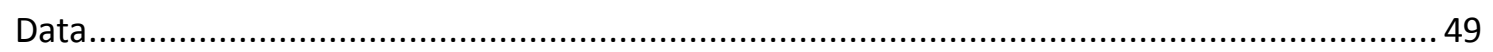

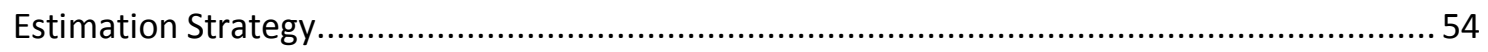

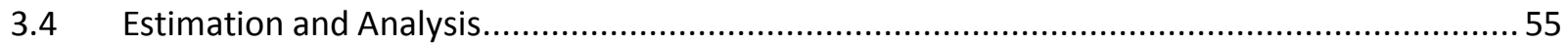

Results: OLS Estimates of Fundraising with Pork-Barrel Spending ......................................56

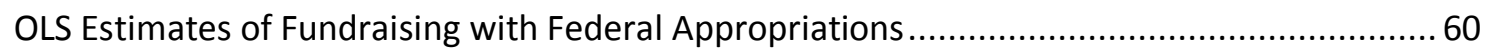

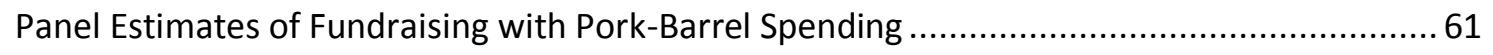

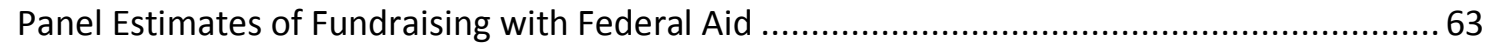

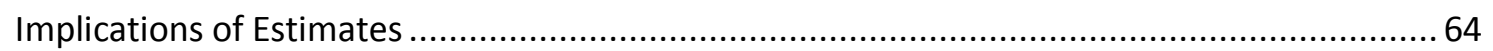

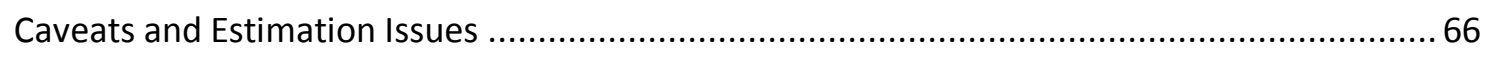

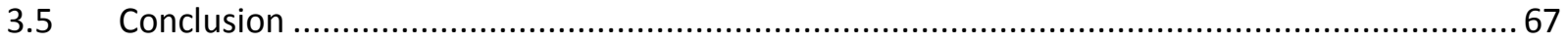

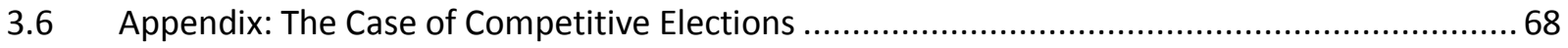

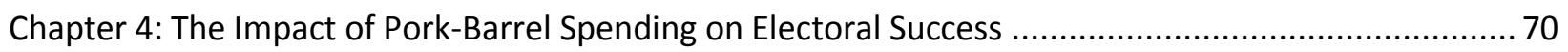

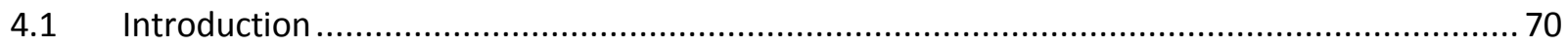

4.2 Pork-Barrel Spending, Fundraising and Electoral Success ................................................... 71

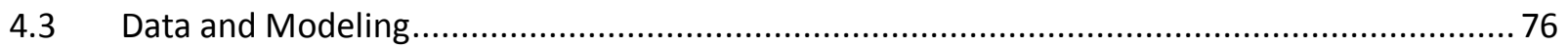

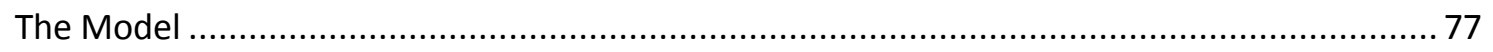

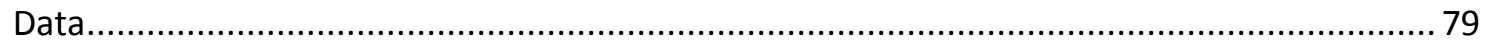

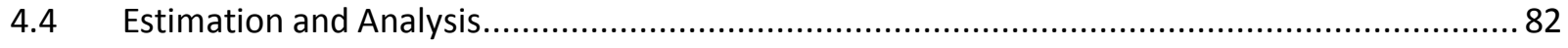

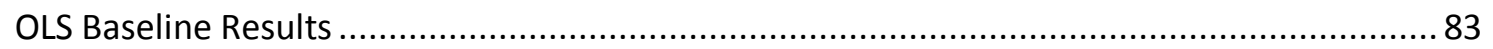

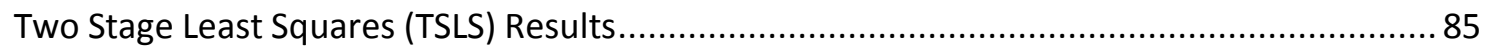

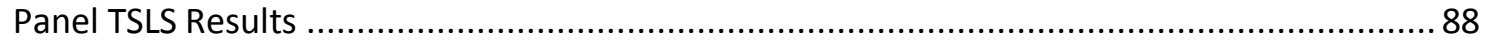

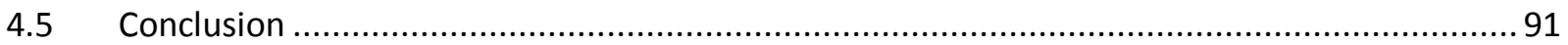

Chapter 5: Pork-Barrel Spending and the Tragedy of the Commons ................................................ 94

$5.1 \quad$ Pork-Barrel Spending as a Common Resource ............................................................. 94

5.2 Literature Pertaining to the Fiscal Commons Problem ..................................................... 95

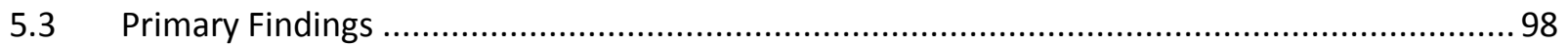

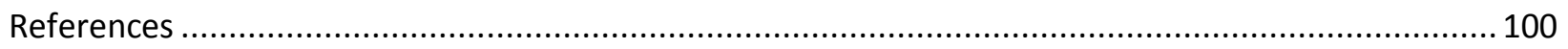




\section{List of Figures}

Figure 1: Pork-Barrel Projects, 1991-2014 (Citizens Against Government Waste) ................................... 4

Figure 2: Pork-Barrel Spending, 1991-2014 (Citizens Against Government Waste) ................................. 4

Figure 3: Average Pork-Barrel Spending by Years to Election........................................................ 51

Figure 4: The Connection Between Pork-Barrel Spending, Fundraising and Electability ........................ 75

Figure 5: Game Theory Setup of Fiscal Commons Problem............................................................... 95 


\section{List of Tables}

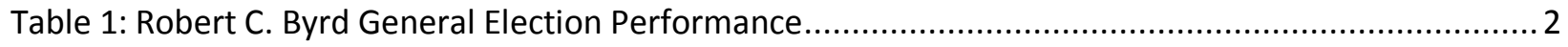

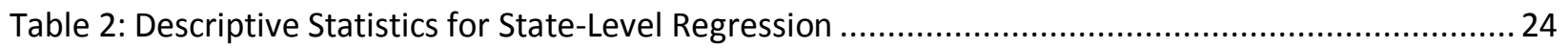

Table 3: Non-spatial Change in Total Employment Regressions (Models 1-3) ..................................... 29

Table 4: Non-spatial Change in Gross State Product Regressions (Models 4-6) ...................................... 31

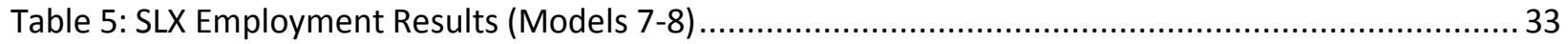

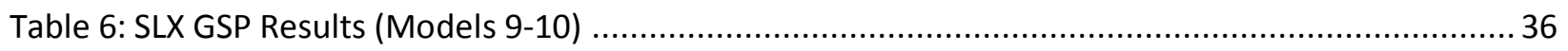

Table 7: Non-spatial Change in Total Employment Regressions (Models 11-13) ................................. 39

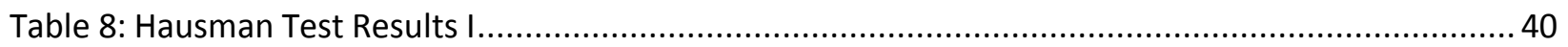

Table 9: Panel Change in Total Employment Regressions (Models 11-13) .......................................... 41

Table 10: Change in Total Employment Regressions (Models 17-19) ............................................... 43

Table 11: Descriptive Statistics for State-Level Regression .............................................................. 54

Table 12: Pooled OLS Regressions using Pork-Barrel Spending (Regressions 1-4) ............................... 59

Table 13: Pooled OLS Regressions using Federal Aid to States (Regressions 5-8) ................................6 60

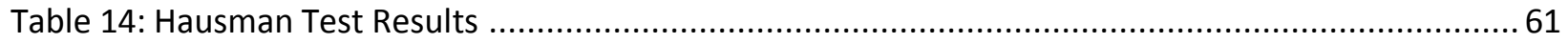

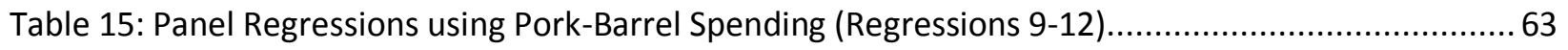

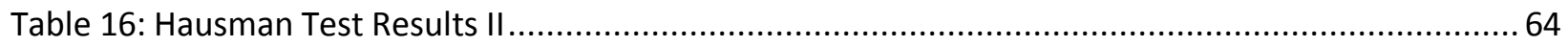

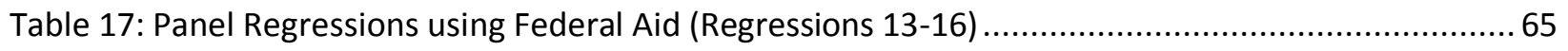

Table 18: Competitive Pooled OLS Regressions using Pork-Barrel Spending (Regressions 1-4)...............69

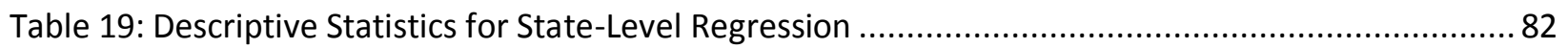

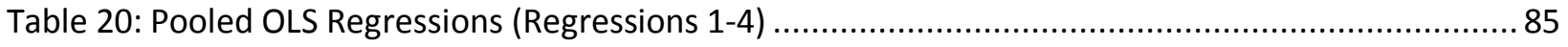

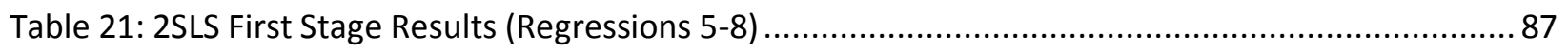

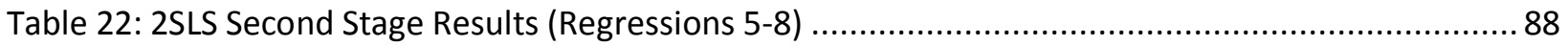

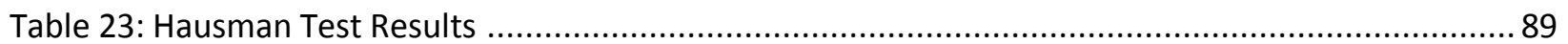

Table 24: 3SLS First Stage Results (\% of Vote in General Election) …................................................. 90

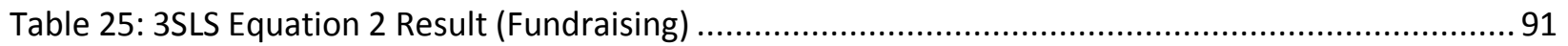




\title{
Chapter 1: The Institutions of Pork-Barrel Spending
}

\begin{abstract}
Pork-barrel spending is used extensively by incumbent candidates for a variety of reasons, including for the purposes of re-election. This chapter provides an introduction to pork-barrel spending in addition to the institutions of pork-barrel spending. This chapter concludes with a primer of spatial econometrics.
\end{abstract}

\subsection{Introduction}

One of the key challenges a politician faces is re-election. Incumbents have a variety of tools at their disposal including the use of earmarks. Earmarks, also sometimes referred to as "porkbarrel spending" or "pork bills", are specific spending projects which are inserted into other, larger bills. In fact, most of the time, the earmark legislation is completely unrelated to the original bill. Pork-barrel projects have been a major source of political controversy over the past two decades. According to America.gov, "pork-barrel spending is the appropriation of federal money for localized projects secured solely or primarily to bring money into a representative's district." Even though the costs are spread out over the entire national tax base, the benefits are very concentrated. As I will show over this dissertation, politicians are able to use porkbarrel spending to their advantage.

Robert C. Byrd, the late Senator from the state of West Virginia was known as the 'King of Pork.' In fact, his projects were commonly referred to as 'Byrd Droppings.' During his tenure in the U.S. Senate, Byrd was notorious for his ability to appropriate federal money for projects in West Virginia. From 1991 until his death in 2010, he brought in over \$4 billion worth of pork. Byrd once quipped "when I was a member of the West Virginia House of Delegates [in the 1950's], West Virginia had four miles of divided highway. Four miles. Today the state has about 37,000 miles of highway." Another hallmark of Byrd's term in Senate was his dominance in 
elections. Table 1 shows Byrd's performance in general elections. Other than the election in which he originally won his seat, Byrd never received less than $64 \%$ of the vote in the general election. While Byrd's ability to appropriate pork-barrel money and his ability to win elections may be a coincidence, there is evidence that incumbents have the ability to use this type of money in their favor.

Table 1: Robert C. Byrd General Election Performance

\begin{tabular}{|c|c|}
\hline Year & \% of Votes \\
\hline 1958 & $59 \%$ \\
1964 & $68 \%$ \\
1970 & $78 \%$ \\
1976 & $100 \%$ \\
1982 & $68 \%$ \\
1988 & $65 \%$ \\
1994 & $69 \%$ \\
2000 & $78 \%$ \\
2006 & $64 \%$ \\
\hline
\end{tabular}

Citizens Against Government Waste (CAGW) gives seven criteria which can be used to determine if a specific spending bill can be classified as 'pork-barrel' spending. The seven criteria are as follows: the bill was requested by only one chamber of Congress, the bill was not specifically authorized, the project was not competitively awarded, the spending was not requested by the president, the spending greatly exceeds the President's budget (or the previous year's spending), the bill is not subject to Congressional hearings, or the project only serves a local or special interest. For the CAGW to consider certain spending as a pork-barrel project, the spending must fall into at least one of the given categories, but the CAGW finds that most of the projects satisfy at least two of the criteria (Waste 2001-2012). 
The aim of this chapter is to examine the core methodology and past research pertaining to special-interest legislation. The information from this chapter is used heavily in the next three chapters of the dissertation. The first part of the paper summarizes the institutional reasoning behind earmark legislation along with the need for coalition formation. The second part looks at the need for coalitions when pork-barrel spending is available as well as some theoretical underpinnings of coalition formation. The third and final part of this chapter provides a primer of spatial econometrics which is used later in this dissertation.

\subsection{The Institutions of Earmark Legislation}

Even though earmarks are not a major component of total government spending, they are typically some of the most scrutinized aspects of legislation as people perceive the earmark projects as inefficient. From 1991-2006, the number of earmark projects increased from around 500 per year to around 14,000 per year. In 2006, more attention was placed on the increasing size of the federal budget, so the number of projects fell significantly. Outside of a spike in 2008, the number of projects gradually fell until a moratorium was issued in 2012.

The recent decline can be attributed to both the added scrutiny faced by legislators for wasteful spending along with the general deadlock that has plagued the United States Congress over the past few years. One issue not discussed is the recent change in the definition of "porkbarrel" spending. As politicians attempt to reduce wasteful spending, they recategorize these projects to avoid the negative stigma attached to "pork-barrel politics." For example, the Republican Party enacted a ban on pork-barrel projects (Raju 2010), but Republican legislators have simply found other ways to direct funding to their district (Tiron 2012). 
Figure 1 shows the number of earmark projects over the past two decades while Figure 2 displays the total amount of money spent on earmark projects over the same period of time (Waste 2008-2010).

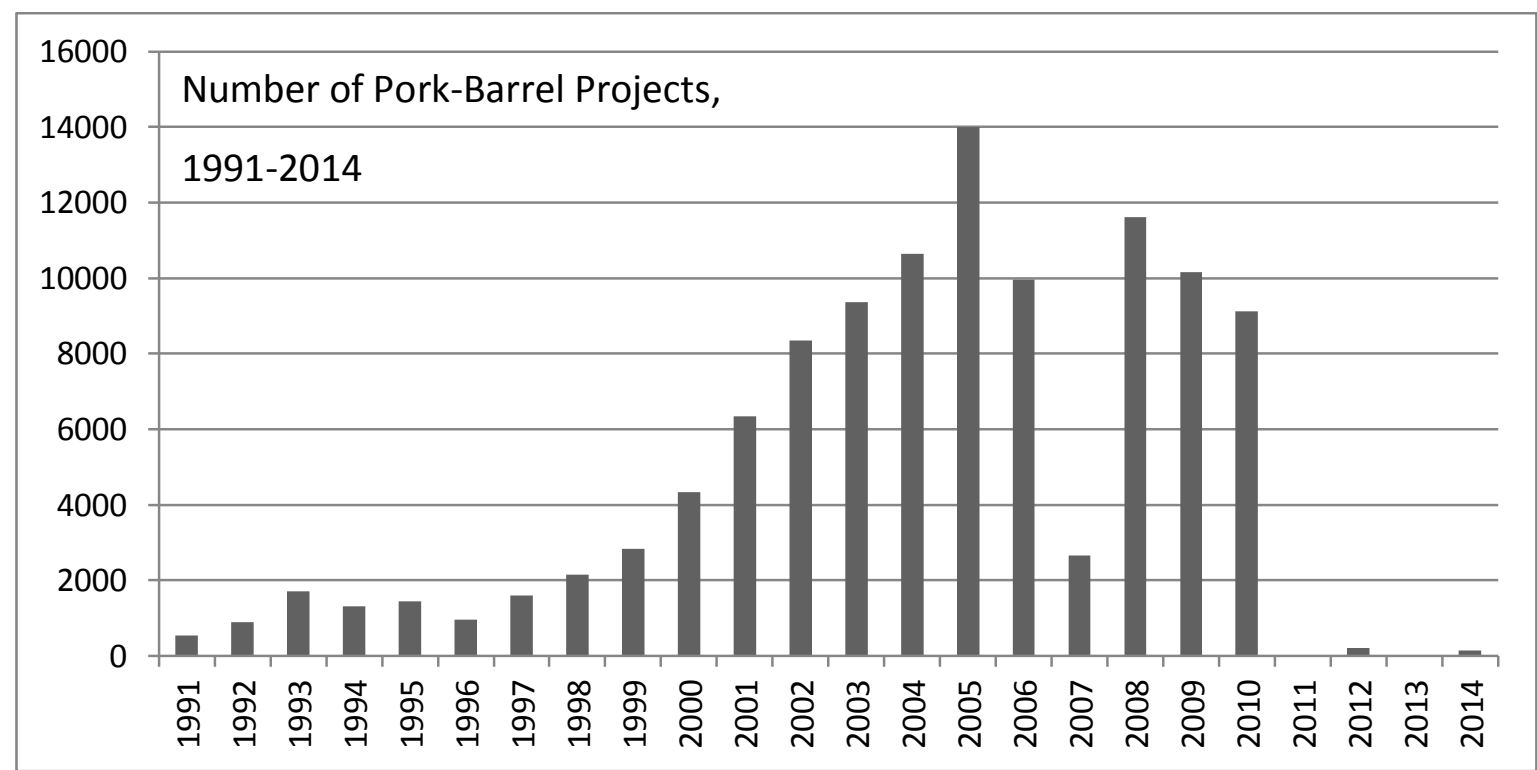

Figure 1: Pork-Barrel Projects, 1991-2014 (Citizens Against Government Waste)

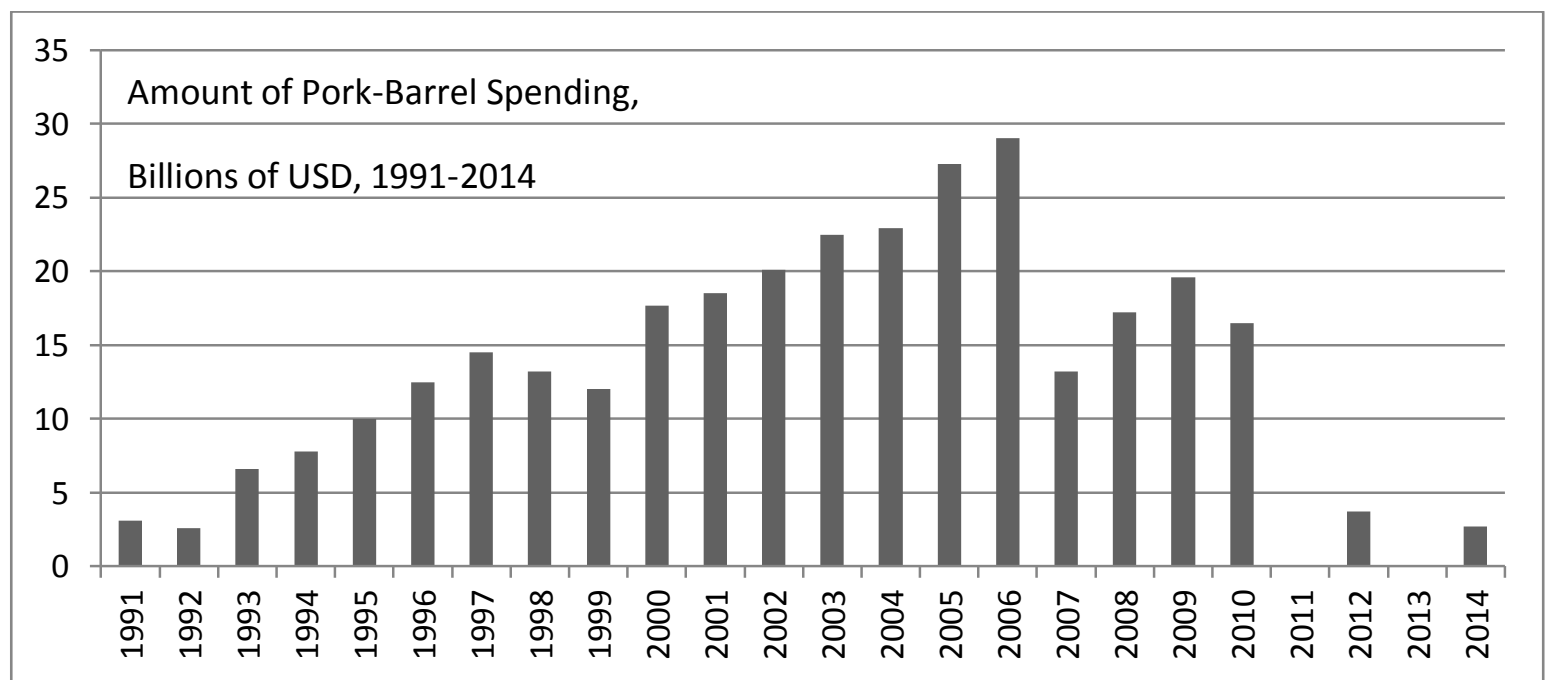

Figure 2: Pork-Barrel Spending, 1991-2014 (Citizens Against Government Waste)

One area of interest is determining the reason for the rapid growth in pork-barrel spending. One explanation is that pork-barrel spending is subject to the common resource problem because the cost of earmarks are borne by everyone yet the benefits are spatially 
concentrated. For instance, a new regional highway may provide benefits to the area that it services, typically only a handful of Congressional districts, yet the cost is equally-shared by each taxpayer. Weingast explains this phenomenon as the Law of $1 / n$, since a district that receives the earmark receives the full benefit, yet bears only $1 / n$ of the cost, where $n$ is the number of districts. Because districts do not bear the full cost of earmark spending, the end result is a surplus of pork-barrel projects.

The general public often criticizes pork-barrel projects as they are often inefficient meaning that the total economic costs exceed the total economic benefits. The efficiency of earmark spending has been repeatedly questioned, even by government officials. In fact, in 2011 , the United States General Accountability Office (GAO) issued a report stating that the government could save over $\$ 100$ billion over the next decade by cutting some of the most wasteful programs and projects, many of them associated with earmarked spending (Paletta 2011). In another case, the Inspector General of the Department of Transportation produced a report in which he noted that many of the transportation projects that were funded through earmark spending were classified as low-priority projects and had not gone through the normal project review process. Further, many of these low-priority projects were being funded over other projects which were viewed as higher-priority and higher-need (Scovel III 2007).

Before proceeding any further, it is important to point out the difference between spending on public goods and earmark spending. A theoretical framework which examines this difference finds that the socially optimal level of spending allocates all funding to public goods and no funding to earmark projects. But, legislators prefer public goods which are smaller than socially optimal and earmark projects which are larger than optimal (non-zero.) This is because earmark 
projects are typically more visible than public good projects. For instance, a legislator would gain little recognition for voting to approve the annual funding for the military. Conversely, that same legislator gains more notoriety if they secure funding to build a brand new military base in their district. As the size of the party increases, earmark spending decreases while public good spending increases due to the fact that the party must internalize special-interest costs as the number of party members grows larger. (Primo and Snyder 2010).

Even though pork-barrel spending has a negative stigma attached to it, politicians still pursue these projects. One of the reasons pork-barrel spending is still prevalent is due to legislative shirking. While legislative ideology is a legislator's personal belief, legislative shirking is when a legislator breaks a campaign promise for political gain (Bender and Lott 1996). For example, a legislator may break a spending reduction promise in order to receive a large amount of federal funding. While this may go against the politician's personal beliefs, this action was taken benefit the legislator's constituents and possible the politician's re-election chances. In any case, the legislator must be sure that the bill is actually passed in order to avoid the situation where the legislator breaks her campaign promise but brings no money into her district. Constituents are willing to overlook a broken campaign promise if the legislator is able to attract a large earmark project to the district. In order to fully appreciate the situation, a more thorough examination of coalition theory is required.

\subsection{Theory of Coalitions}

Because earmark projects have a limited spatial impact it is very difficult to get a single earmark project passed. Thus, politicians must form coalitions with other legislators. This leads to legislators engaging in vote-trading, also referred to as logrolling. Under this scheme, 
legislators vote for other projects in order to gain support for their project. Since specialinterest projects are typically expensive, legislators attempt to form a minimum-winning coalition in order to have their projects passed while minimizing the total cost of the other legislators' projects. Yet, coalitions are typically oversized. One reason is the negative stigma associated with special-interest spending. While voters are generally happy with specialinterest projects in their district, supporting projects in other districts or states is undesirable. For instance, voters in West Virginia are upset paying for a forestry research program in Oregon. On the other hand, those same voters are happy if a similar program is instituted in West Virginia. Therefore, legislators create oversized special-interest coalitions to engage in "blame avoidance." If both parties engage in special-interest politics, then neither can criticize the other party. Essentially, if a legislator is able to boast the projects they secured, the constituents may overlook the other, non-beneficial projects (Balla, Lawrence et al. 2002).

Two other explanations about the consistent surplus of earmark projects pertain to procedural measures. The first is that due to the cyclical nature of politics as the majority party knows that they will eventually become the minority. Thus, by cooperating with the minority today, the hope is that when the party becomes the minority, the new majority will also cooperate on special-interest projects. The second possibility is that the majority party will only respect the minority party's procedural rights when there are interparty coalitions, thus there is an incentive for legislators to join cross-party coalitions (Binder 1997).

Over the past few years, a major talking point in many election campaigns has been a reduction in wasteful government spending. One method to accomplish spending reductions is a decrease in earmark spending; but, politicians that make this promise rarely keep it. Party 
discipline is a main reason for the failure of these spending reduction plans. By definition, party discipline is the reward or benefit associated with voting for or against the official party position on some bill. The benefit to belonging to a party is the low-cost "branding" associated with the party name. For instance, Republican typically conveys "pro-business" while Democrat conveys "pro-worker" even if those labels are not accurate for the specific legislator. Parties are very interested in maintaining their brand name just as franchises maintain standards for individual stores to preserve the company reputation. Legislators voting against the party brand may be subjected to penalties such as roadblocks in presenting bills, reduced funding for re-election, and expulsion from the party. On the other hand, a party leader must be careful not to overextend the voting requirements on its party members. Constantly forcing legislators to vote against their own constituents' interests causes the branding to be less desirable (Snyder and Groseclose 2000).

For instance, consider the West Virginia Democrats and environmental regulations. It is expected that they will vote against most of the new Environmental Protection Agency (EPA) regulations even though the Democrats typically vote for new environmental regulations. The other party members assume that they will vote against the EPA regulations not because they are siding with the Republican Party; rather, it is because they know the legislators must vote in favor of their constituents' interests periodically in order to remain in office. Legislators use this to rationalize voting for special-interest bills which will help the legislator's district yet goes against the branding of the party.

Another finding is that parties tend to be centralized coalitions, meaning that the central party has control over party members at the national, state, and local level. For instance, the 
Republican party not only controls large amounts of funding for national elections such as the presidential or Congressional races, but the party also controls re-election funding for state and important local races. Therefore, the amount of distributive projects is lower when there is a strong central party as politicians must adhere to party restrictions in order to secure future reelection funding.

The process of creating a coalition is also an important area of study. Some questions that are have been addressed in the coalition formation literature deal with who gets into the coalition, how large the coalition becomes, how long a coalition takes to form, and how long the coalition lasts. One important factor is the optimal size of the coalition. If a coalition is too large, then the benefits derived from coalition membership are over-dispersed amongst the group members. On the other hand, if a coalition is too small, then even if it is a majority coalition, it can be prone to possible defection by marginal members (Diermeier, Eraslan et al. 2002). Therefore, forming the minimum-winning coalition is one strategy which maximizes the benefits of being in a coalition while minimizing the costs, which can be quantified as the dispersion of benefits amongst members. As the slices of the pie get smaller and smaller, the benefit of being in a coalition decreases. The traditional theory is that the minimum winning coalition is "50\% plus one" (Riker 1962; Koehler 1975; Brams and Fishburn 1996) but an alternate viewpoint is that the two-thirds supermajority is more cost-effective as it minimizes the importance and the cost of the marginal members of the coalition (Groseclose and Snyder 1996).

The second question pertaining to coalition formation deals with how long it actually takes to form. Coalition formation does not simply occur at a large gathering where groups pick 
members. Instead, coalition formation is the result of backdoor meetings and trial-and-error. For example, a majority formation may be created, yet the members are unable to agree on what to vote for rendering the coalition ineffective. A study found that on average, it takes 1.7 attempts to create a working coalition in a sample of European parliamentary governments (Diermeier and Merlo 2003). The formation of coalitions is clearly not a clear-cut process.

The final question relating to coalition formation is how long it stays together. As mentioned, just because a coalition is formed does not mean it is effective. The same paper found that the average duration the European coalitions stayed together was 611 days. Some factors which can impact the duration of the coalition are no-confidence votes and bicameral legislatures. The lack of a no-confidence vote in a constitution decreases the average duration of a coalition as the necessity of a strong coalition is diminished. Further, it was found that bicameral legislatures actually have no impact on the duration of coalitions.

\subsection{Spatial Econometrics Primer}

One of the newest branches of econometrics is the inclusion of spatial considerations. In an ordinary least squares (OLS) regression, the impact of a dependent or independent variable in region $x$ is assumed to have no impact on the values of the dependent and independent variables in district $y$. Using the spatial econometric framework, it is now possible to include the spatially-correlated impacts.

The first difference between a spatial and non-spatial model is the inclusion of a weightmatrix. A row-normalized contiguity weight matrix considers two geographic areas to be neighbors if there is some physical border between them. If two areas are neighbors, the binary weight variable is 1 , else it is 0 . A more preferred method is the nearest-neighbors weight 
matrix in which the $n$ nearest states or districts, as defined by the straight line, centroid distance between districts, are considered to be neighbors while the others are not. This allows for two regions which may not actually have a border, yet have influence on each other, be counted as neighbors. This is especially useful when considering geographical areas like the northeastern United States since many of the smaller states are not contiguous yet they have a significant impact on each other. Some econometricians disagree with the use of the nearestneighbors weight matrix because of the perceived sensitivity to the number of nearest neighbors; but, it has been shown that the number of nearest neighbors does not have any significant impact on the outcome of the coefficients (LeSage and Pace 2010).

I will discuss four different spatial models below. First, the spatial error model (SEM) best fits the case where the values of the independent variable from one district can impact the dependent variables of other districts. Formally, the SEM model can be written:

$$
\begin{gathered}
y=x \beta+\mu \\
u=\lambda W u+\varepsilon
\end{gathered}
$$

In order to conceptualize the use of the SEM model, consider employee mobility. Because many people do not live in the same district in which they work, not using a spatial model would ignore the relationship between independent variables in one county and the dependent variable of a neighboring county. For instance, an increase in the poverty level in the inner-city would likely not cause any significant change to the employment in the district because most city employment, as mentioned earlier, is higher-skilled white-collar work. But, if the poverty levels increase in the surrounding, suburban districts, the impact on employment in the urban, inner-city, district may be much more distinct. 
The second model that can be used is the Spatial Autoregressive Model (SAR). In this model, the value of the dependent variable in one district can have an impact on the dependent variable of a neighboring district. The SAR model closely resembles an autoregressive model in time-series econometrics with the major difference being the use of space (Beaudry, Green et al. 2007) as opposed to time. Formally, the SAR model can be written

$$
\begin{gathered}
y=\rho W y+x \beta+\varepsilon \\
\varepsilon \sim N\left(0, \sigma^{2} I_{n}\right)
\end{gathered}
$$

In order to conceptualize the use of the SAR model, consider the fact that the level of employment in one district has an impact on employment in surrounding districts (Beaudry, Green et al. 2007). On one hand, an employment increase in one district could negatively impact the level of employment in surrounding districts due to backwash effects. If the employment base does not increase and the labor force simply shifts from one district to another, then there would be a negative relationship. On the other hand, there could be spread effects where economic growth in one district could spill over to neighboring districts and promote employment growth throughout the region.

The third model that is considered is the Spatial Durbin Model (SDM) which simply incorporates both the spatial lag and spatial autoregressive aspects of the SEM and SAR models. The SDM can be written as

$$
y=\rho W y+x \beta+W X \theta+\varepsilon, \varepsilon \sim N\left(0, \sigma^{2} I_{n}\right)
$$

The conceptualization of the SDM can be thought of as a combination of the explanation of both the SAR and SEM models. 
The fourth and final model considered is the spatial lag model (SLX). The spatial lag model is considered to be a 'local model.' Unlike the SAR model which is considered a 'global model,' the SLX only considers the spatial impact of the state or district's nearest neighbor. The SLX model can be written as

$$
y=x \beta+W x \theta+\varepsilon
$$

where $x$ is the set of independent observations, $\beta$ is the set of non-spatial coefficients, $W$ is the weight matrix and $\theta$ is the set of spatial coefficients. The $W x$ variable is used to consider the impact of neighbors' independent variables on the state or district on interest.

In order to determine whether spatial modeling should be used, it is necessary to conduct a Lagrange Multiplier testing procedure to test for the presence of both spatial error and spatial autocorrelation (Anselin, Bera et al. 1996; Florax, Folmer et al. 2003). If both spatial error and spatial autoregressivity are detected, then the spatial Durbin model is appropriate.

Recent improvements in technology have even allowed to the execution of spatial panel models which can use fixed effects, random effects and time effects (Anselin, LeGallo et al. 2008; Elhorst 2010). This advance has allowed researchers to consider the impacts of policies not only spatially, but also over time. One problem faced by spatial panel models was the biased estimators yielded by spatial regressions. In fact, when the conducting a spatial panel model with fixed and time-effects, the $\beta, \delta$, and $\sigma^{2}$ values were all biased (Elhorst 2010; Lee and Yu 2010). Therefore, a new set of estimators was derived which eliminated the problem of parameter bias (Lee and Yu 2010). As long as the bias-correction routine is utilized, future spatial panel regressions should no longer be prone to estimation problems. 
Unlike a non-spatial panel model, the coefficients of the SAR and SDM have no meaning so using the standard interpretation of the coefficients leads to incorrect conclusions (LeSage and Pace 2009). In order to properly analyze the results, the coefficients must be re-calculated to find the direct and indirect effects. The direct effect is similar to the standard interpretation of a beta coefficient; that is, as the $x$ variable increases by 1 , the dependent variable changes by $\beta_{i}$. But, spatial influence is very important when using spatial econometrics, so the impact on other geographic regions must also be calculated. Specifically, the indirect effect is the total impact that a change in an independent variable or the spatial autoregressive term in region $x$ has on the dependent variables in other regions. Essentially, the indirect effects can be used to calculate the spillovers from one region to another.

The impact of earmark spending is shown to have a strong spatial impact; thus, the use of spatial econometrics throughout this dissertation is paramount to the study of earmark spending on factors such as employment, wages and income distributions.

\subsection{Conclusion}

This dissertation examines several topics pertaining to the legislative uses of pork-barrel spending, specifically focusing on how legislators may benefit from participating in pork-barrel projects. The second chapter of this dissertation examines the impact pork-barrel spending has on state-level employment. Because employment gains can be beneficial to an incumbent and their chances at re-election, this chapter will determine if pork-barrel spending actually does have any impact on employment. I find that pork-barrel spending does create jobs in the shortrun, but many of those jobs disappear after only one year. Further, job increases in one state due to pork-barrel spending can lead to reductions in employment in surrounding states. 
The third chapter focuses on the role pork-barrel spending has on the incumbent's ability to fundraise. Specifically, I find that pork-barrel spending does have a positive and significant relationship with fundraising indicating a reward system for major contributors. I also attempt to determine if general federal appropriations have a similar impact on fundraising but find that general federal appropriations have a negligible impact an incumbent's ability to fundraise.

The fourth chapter takes the results from the third chapter and produces a model similar to that of Stratmann (2013) in which two-stage and three-stage models are used which addresses the endogenous relationship between pork-barrel spending, fundraising and electoral success.

The fifth and final chapter summarizes the results by determining whether or not porkbarrel spending suffers from a Tragedy of the Commons which would indicate a Fiscal Commons Problem. 


\title{
Chapter 2: Pork-Barrel Spending and State Employment Levels
} Do Targeted National Expenditures Increase State Employment in the Long Run?

\begin{abstract}
A targeted national expenditure, also known as pork-barrel spending, is defined as federal project which is funded by the national tax base yet only benefits a small, localized population. Anecdotally, this type of spending is often criticized as shortsighted, inefficient and wasteful. This paper incorporates pork-barrel spending into existing research on the drivers of state economic growth to determine the role of pork-barrel spending on both state employment and gross state product. First, I find that many of the initial-year economic conditions that drive employment in MSAs also drive employment at the state-level. Second, I find that pork-barrel spending also influences employment levels, but the effect tends to be temporary. Specifically, for every one million dollars of pork-barrel appropriated by a state, total employment in the state increases by around 735 jobs in the year the funding is secured. However, less than 100 of those jobs remain the following year. This gives credibility to the argument that pork-barrel spending is used to support short-sighted political goals such as re-election. Finally, using a spatial lag model, I find that the benefits of porkbarrel spending do not spill across state lines providing evidence that pork-barrel spending only benefits a concentrated population.
\end{abstract}

\subsection{Introduction}

Pork-barrel projects have been a major source of political controversy over the past two decades because they are funded with national tax revenues yet only benefit a small, localized population. At the federal level, this occurs when a legislator is able to finance a project in their district-a bridge, highway, or park - with tax revenue collected from the entire country. Anecdotally, many pundits see pork-barrel projects as wasteful; but, pork-barrel projects are not necessarily wasteful. Rather, many of these projects have a narrow geographical benefit which generates criticism from those that do not receive any benefit. Generally, it is believed that legislators pursue this funding in order to bolster the chances at re-election. ${ }^{1}$

\footnotetext{
${ }^{1}$ Stratmann (2013) summarizes the available literature. While there are several papers establishing a theoretical foundation for using pork-barrel spending to enhance the likelihood of re-election but very few exist which find an empirical link.
} 
There are several ways that pork-barrel spending may advantage incumbents. First, insofar as local voters benefit from such projects, they will be more inclined to vote for the incumbents who obtained them. Second, insofar as the projects benefit organized groups, such groups are likely to contribute to the re-election campaigns of incumbents, which also improves the likelihood of reelection. A third possible channel is through the economic effects of the spending itself, which tend to increase employment. The construction and maintenance of projects clearly require labor, capital, etc. Jobs are thus both directly and indirectly created. Some persons are directly employed and subsequent purchases by all the input providers create other new jobs ${ }^{2}$. Those whose income has been increased by pork barrel projects are also likely to support candidates at the voting booth and with their campaign contributions. This paper examines the effects of pork barrel spending on job creation.

One major focus of research in labor economics is determining the factors that contribute to increases in employment. This type of research has been conducted at both the national and subnational levels. In general, the results suggest that both economic and public policies matter. Political jurisdictions compete with each other for residents and tax base using a combination of fiscal packages (tax and expenditure combinations). Among the more important expenditures are those on education and infrastructure. Other relevant variables are beyond the control of local and national governments such as natural resource endowments and location. While some literature has considered the role of government policy on employment,

\footnotetext{
${ }^{2}$ There is a substantial political science literature that suggests incumbents are helped by local pork barrel spending. Even if they genuinely care about their constituents, they still need to focus on being re-elected in order to remain in office so they can continue to cater to the needs of their constituents. (Bickers \& Stein, 1996; Ferejohn \& Krehbiel, 1987; Inman, 1988; Keefer \& Khemani, 2009; Shepsle, Dickson, \& Van Houweling, 2002; Shepsle \& Weingast, 1981; Weingast, 1979; Weingast, Shepsle, \& Johnsen, 1981).
} 
to this point it has neglected the extent to which targeted projects affect local employment levels and economic growth rates.

This paper uses established labor models to determine whether or not pork barrel spending has an impact on employment. The results suggest that pork barrel spending increases state employment levels, but these effects do not seem to be permanent. For every one million dollars spent, total employment in the state increases by around 735 jobs in the year the funding is secured. However, 650 jobs are lost the following year. In general, the results suggest that targeted expenditures, such as those associated with "shovel ready projects," have a temporary, but substantial effect on employment. This is plausible due to the prominence of construction and construction-related jobs associated with pork-barrel projects. In addition to the impact on employment, there are corresponding increases in the gross state product, but this impact is also temporary.

\subsection{Public Policies and State Employment}

The top priority for most politicians is to be re-elected. If a legislator presides over a district with high levels of unemployment, they may have a more difficult time being re-elected (Alt 1985). Therefore, the legislator has an incentive to do everything in their power to provide opportunities for employment, especially when job growth is lacking. One of many ways that a legislator may be able to increase employment is through the appropriation of earmarked spending projects. The government can impact state employment through such policies as an increase in government expenditures (Rephann and Isserman 1994), changes in the tax level (Nickell 2003), and in minimum wage law (Zavodny 2000). In general, policies that promote a more business friendly environment increase state economic growth (Gwartney and Lawson 1996; Karabegović, McMahon et al. 2002; Miller, Holmes et al. 2012; Stansel 2013). 
Other possible policies include employment subsidies, micro-credit organizations, and public works projects. Policies that promote public capital investments also have a positive and significant impact on employment growth (Munnell and Cook 1990). Tax credits to firms for the creation of new, full-time jobs have also been shown to have a positive and significant impact on employment levels. Nonetheless, the efficiency of such programs are still in question (Faulk 2002) because the taxes and borrowing necessary to fund the programs tends to reduce jobs, as do changes in policy that increase regulatory uncertainty. Tax revenue has both direct and indirect burdens that tend to reduce employment. Thus, spending an additional dollar on one program may increase jobs in the targeted area, but reduce them in others.

In addition, government programs compete with each other for funds. Spending a dollar of tax revenue "here" means there is one less dollar available to be spent on other projects and programs "there." With respect to earmarked spending, one additional dollar appropriated for Florida means that there is one less dollar available for the rest of the forty-nine states (and the rest of the world.) Also, politicians engaging in demand-side policies are typically more interested in the visibility of the program and not so much with the efficiency or effectiveness of the spending. In fact, the United Nations found that many international demand-side funding programs are riddled with fraud and are typically ineffective and a 'waste of money' (Nations 2007).

This paper looks specifically at the effects of targeted national expenditures in the United States, more commonly referred to as earmarks or pork-barrel spending. The goal of this paper is to determine the impact of pork-barrel spending on employment. 


\subsection{Model, Data, and Estimation Strategy}

I use a labor market model based on Blumenthal, Wolman and Hill (2009) and Glaeser et al. (1992) for purposes of estimation. These models were developed to examine factors that drive employment in urban areas, and rely upon a broad range of demographic characteristics to estimate MSA employment and GNP. Their results suggest that business environment, natural amenities, and economic age are main drivers of urban economic performance, other things being equal. They explore how initial values of such economic fundamentals affect the ten year average growth rates in employment and per capita GMP in large cities. Ten years is considered a sufficient time for long run responses to favorable or unfavorable initial conditions to affect the overall metropolitan area's economy. Blumenthal et al (2009) and Glaeser (1992) also use a ten-year period to capture the long run effects of economic fundamentals and public policy on metropolitan employment and economic growth.

The estimation strategy of this paper assumes that the Blumenthal, Wolman and Hill methodology also applies to state economies, but that in addition to economic fundamentals, external grants may also have temporary or permanent effects on employment and economic development. Due to data availability, the present study focuses on the 2001 to 2008 period. In addition to the seven-year ordinary least squares model similar to those of the urban studies, the present analysis also tests for the presence of spatial dependencies. Insofar as employment opportunities generated by earmarked projects may attract workers and firms from neighboring states, this is an obvious concern for the present study. 


\section{Data: Demographics}

In order to apply the Blumenthal, Wolman and Hill (2009) approach, data on state demographics, natural amenities, and business climate were collected for the fifty states in the year 2001, which was used as the base year. In addition, data on state employment, GSP, and earmarked spending were collected for the 2001-2008 period. Data on pork-barrel spending are taken from the Citizens Against Government Waste (CAGW) data set. The CAGW dataset is one of the most commonly used collection of pork-barrel spending having been used in a variety of papers such as Stratmann (2013) and Boyle and Matheson (2009). In addition, it is one of the few datasets which dates back to 1995.

As mentioned earlier, pork-barrel spending is federal money which is used to fund projects with a geographically concentrated benefit. Therefore some view this form of appropriation to the wasteful, especially because many of the projects funded by pork-barrel spending are categorized as "low-need" and likely would not have been funded without pork-barrel spending (Scovel III 2007).

The pork-barrel spending variable takes two different forms. The first variable used is the total amount of state earmarked spending appropriated from 2001 to 2008 . The second uses a set of annual spending variables from 2007-2008. I focus on the spending in the last two years of the period of interest, because these expenditures appear to have the largest effects. These annual expenditures allow tests of the short and long term effects of spending to be separated from one another.

The state demographic variables measure the characteristics of state residents in 2001. These include the level of human capital, race and age. These factors have been shown to 
impact urban labor supplies and employment levels. See, for example, Levy, Darst, Wolman and Young (2008) and Wolman, Levy, Young and Blumenthal (2008).

Human capital affects marginal product and the quality of job opportunities in the present and in the future (Card 1999). Two measures of state human capital were collected, the percentage of adults in a state with a high school diploma in 2001 and the percentage of adults with a bachelor's degree in 2001. Both are taken from the US Census. In general, having a high school diploma measures the population's access to basic education while having a college diploma indicates that an individual possesses a more specialized skill.

The age distribution of a state can also has direct effects on the potential supply of labor. For example, if a large percentage of the populace belongs to the 'dependent population'; that is, children under the age of 18 and adults over the age of 65 , the potential labor supply tends to be smaller. Both child labor laws and eligibility requirements for retirement programs exclude most of those populations from the labor force. Although beyond the scope of this paper, a large fraction of persons of "dependent" age tends to increase the demand for education and/or healthcare services without producing the tax revenues necessary to support those services. This reduces state funds available for employment promoting expenditures. The percentage of the state's population that was under 18 in 2001 and the percentage of the state's population that was aged 65 or older in 2001 is included in the demographic variables each taken from the US Census. Finally, the logarithm of the 2001 population of the state is used to account for a state's employment potential. 


\section{Data: Capital Stock and Business Climate}

In addition to the initial composition of the labor force, the Blumenthal, Wolman and Hill (2009) results suggest that the preexisting capital stock and location affect prospects for economic development. Two components of the economic structure of a state are used: industry composition and labor costs. The location quotient is one way to measure the industrial composition of an area. The location quotient (LQ) is formally defined as

$$
L Q=\frac{e_{i} / e}{E_{i} / E}
$$

Where $e_{i}$ is the state-level employment in industry $i, e$ is the total state employment, $E_{i}$ is the national employment in industry I and $E$ is the total employment in the United States. The LQ allows for a straightforward comparison of the proportion of the state workforce in a certain industry against the proportion of the national workforce in the same industry. For instance, $6.08 \%$ of the West Virginia workforce is in the natural resources and mining sector which seems to be relative unimportant; but, its relative significance becomes apparent as only $1.80 \%$ of the US workforce is employed in the natural resources and mining sector.

The 2001 location quotients for the manufacturing industry and the finance, insurance, and real estate (FIRE) industry as classified by the North American Industry Classification System (NAICS) are used to characterize the preexisting capital stock and networks. These data are taken from the Bureau of Labor Statistics.

Past studies have established that an area with a high manufacturing LQ experience higherthan-average job losses due to the decay of the American manufacturing industry (Glaeser, Kallal et al. 1992; Glaeser, Scheinkman et al. 1995; Blumenthal, Wolman et al. 2009). On the other hand, the FIRE sector has experienced growth over the past several decades so there 
should be a positive relationship between the FIRE LQ and change in employment. States that started with higher shares of FIRE employment should have experienced higher than average employment growth, all else equal.

The average cost of labor in a state is measured with the average annual wage rate. Higher wage rates in one state can cause it to be less competitive versus other similar states. It has been shown that regions with higher relative wage rates will shed employment over time (Henderson, Kuncoro et al. 1995). The 2001 average yearly wage rate per job is used and is also from the Bureau of Labor Statistics.

Table 2: Descriptive Statistics for State-Level Regression

\begin{tabular}{|l|c|c|c|c|c|}
\hline Variable & Source & Mean & St. Dev. & Min & Max \\
\hline Change in Total Employment (thous. of jobs) & BLS & 84.81 & 193.14 & -507.9 & $1,006.9$ \\
\hline Change in Gross State Product (mil\$) & BLS & 87.96 & 113.11 & 6.09 & 630.00 \\
\hline Aggregate Pork Spending (bil\$) & CAGW & 1.30 & 0.878 & 0.124 & 4.13 \\
\hline 2008 Pork Spending (mil\$) & CAGW & 202.79 & 133.61 & 14.3 & 666.4 \\
\hline 2007 Pork Spending (mil\$) & CAGW & 31.51 & 55.73 & 0 & 319.7 \\
\hline LQ Manufacturing & BEA & .984 & .360 & .25 & 1.65 \\
\hline LQ FIRE & BEA & .965 & .194 & .71 & 1.59 \\
\hline Log(Population) & Census & 6.54 & .444 & 5.69 & 7.54 \\
\hline \% of Population under Age 18 & Census & 24.3 & 1.74 & 21.3 & 31.1 \\
\hline \% of Population over Age 65 & Census & 12.6 & 1.71 & 6.6 & 16.8 \\
\hline \% of Population who are Black & Census & 9.90 & 9.58 & 0.3 & 36.3 \\
\hline \% of Adults with High School Diploma & Census & 86.9 & 3.41 & 79.9 & 91.8 \\
\hline \% of Adults with Bachelor's Degree & Census & 27.2 & 4.73 & 17.3 & 38.2 \\
\hline Average Wage (thousands of \$) & BLS & 33.1 & 5.26 & 25.1 & 46.0 \\
\hline Right-to-Work State* & NRTW & 0.48 & 0.50 & 0 & 1 \\
\hline Average July Temperature* & NOAA & 0.54 & 0.49 & 0 & 1 \\
\hline
\end{tabular}

Note: Variables marked with an asterisk are binary variables.

Next, a state's business climate is considered. As in Blumenthal et. al (2009), this paper uses a binary variable indicating whether or not the state is a 'right-to-work' state. States which have enacted 'right-to-work' legislation make it illegal for a firm to require an employee to belong a 
union. Twenty-two states which have right-to-work legislation and are perceived to be more business-friendly (Holmes 1998).

Finally, a binary variable is used to measure the average July temperature. Specifically, the variable has a value of one if the average July temperature for the state's largest city exceeds the average temperature in the contiguous United States of 74.3 degree Fahrenheit. This variable controls for the impact of warmer weather on labor force migration.

The descriptive statistics and the sources for the data set are shown in table 2.

\section{Estimation Strategy}

Ultimately, while the factors discussed above are important, most studies neglect the impact of directed national expenditures. For example, none of the papers reviewed by Levy, Darst, Wolman and Young (2008) and Wolman, Levy, Young and Blumenthal (2008) acknowledge the role of directed national expenditures in urban employment. In all likelihood, directed spending does not have the same type of an impact as education or infrastructure does at the national level considering the relatively small portion of the federal budget that pork-barrel spending accounts for; but, it may nonetheless affect local employment opportunities. The general structure of the employment regression is as follows:

$$
\text { Change in Employment }=\beta_{i} \cdot \text { pork }+\beta_{j} \cdot X+\varepsilon
$$

Where pork is both the current and lagged pork-barrel spending variables, $X$ is the set of independent variables, $\beta$ is a set of fixed, but unknown coefficients, and $\varepsilon$ is the error term. I also determine if gross state product is impacted by pork-barrel spending using the same empirical framework. 
To determine whether such effects exist, three series of estimates are undertaken. First, the suitability of the Blumenthal, Wolman and Hill (2009) approach for state employment during the given time period is tested. Next, these models are augmented by including earmarked spending variables. Finally, these OLS estimates are augmented by spatial econometric estimates to account for interstate effects of targeted state expenditures. In general, the results suggest that Blumenthal, Wolman and Hill approach can be used to model and estimate state employment levels.

It should be noted that some variables included in Blumenthal et. al were not included in the state-level analysis. Some of them, such as the number of airport departures and age of the city were not included because they were not compatible at the state-level. In addition, a seven-year time period is used instead of a ten-year period for two reasons. First, data availability prevents including time periods before 2001. Second, the crash of the housing market had a serious impact on the market from 2008 and beyond. By focusing on 2001-2008, I

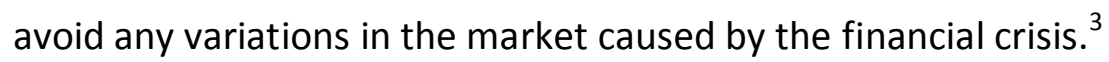

\subsection{Estimation and Analysis}

The two dependent variables focused on in this paper are the change in state total employment and the change in gross state product between 2001 and 2008. The unemployment rate is not used because changes in the unemployment rate can be misleading. For example, a decrease in the unemployment rate could be a result of an increase in employment; or it could be the result of a decrease in the size of the labor force because of emigration or retirement. Employment is likely to better represent the goal of the legislators.

\footnotetext{
${ }^{3}$ I consider different time periods in the appendix.
} 
Three hypotheses are tested: first that urban employment models can be applied to states, second that earmarked federal expenditures affect state employment, and third that these effects are not exclusively realized by the states receiving the targeted expenditures.

The first regression use an ordinary least squares (OLS) approach as in Blumenthal, Wolman and Hill (2009). Replicating the original work ensures that the model performs in the same manner as the original model. The second estimate includes the aggregate pork-barrel spending each state accrued from 2001-2008. The third replaces the aggregated pork-barrel spending variable with the disaggregated pork-barrel spending for 2007 and 2008. Regressions 4-6 replicate the first three regressions using the 7-year change in gross state product as the dependent variable in lieu of the change in total employment.

\section{OLS Estimates of State Employment Effects}

Table 3 displays the results for the OLS estimates the Blumenthal et. al model with and without the effects of earmarked expenditures. The first column replicates the pure Blumenthal et. al. model on state data. In general the results match those of Blumenthal et. al (2009) paper. The location quotient for the FIRE sector, the bachelor's degree variable and the right-to-work state dummy variable are all significant and positively correlated with changes in total employment as expected. The only unexpected result is the sign of the high-school variable which indicates that having a higher percentage of adults with a high school degree leads to job loss. One possible explanation for this result is that having a more educated workforce could lead to higher wages which eventually leads to job losses, but this same effect is not seen in the college variable. In addition, it is likely that there is some relationship between the high school and college education variables. It should also be noted that the size of the coefficients are very 
different; but, this reflects differences in the size of the economic units studied. The original paper was conducted at the metropolitan level, whereas this study focuses on changes in employment at the state-level.

Regression 2 includes the aggregate pork-barrel spending variable. For every \$1 million dollars of pork-barrel spending appropriated from 2001-2008, a net of 34 jobs are created. This amounts to approximately $\$ 29,500$ per job created. The other independent variables continue to behave just as they did in the previous regression. What cannot be determined from regression 2 is whether or not there are temporary jobs created that subsequently disappear over the seven-year period. To account for this, annual expenditures during the last two years of the time period of interest are included. The results from regression 3 show that $\$ 1$ million of pork-barrel spending in 2008 increases employment by 735 jobs. However, similar spending from the prior year is causing jobs to disappear. This can be interpreted as a temporary effect of targeted expenditures.

The first series of estimates suggest that many of the jobs created by pork-barrel spending over the seven years are relatively modest in size. However, there appear to be short term gains, after which jobs begin to disappear, possibly as the direct employment in public capital projects disappears together with indirect employment generated serving those directly employed. ${ }^{4}$

\footnotetext{
${ }^{4}$ It bears noting that the employment numbers do not differentiate among part time and full time jobs, nor between temporary and permanent jobs.
} 
Table 3: Non-spatial Change in Total Employment Regressions (Models 1-3)

\begin{tabular}{|c|c|c|c|}
\hline Variable & $\begin{array}{l}\text { Model } 1 \\
\text { No Pork }\end{array}$ & $\begin{array}{c}\text { Model } 2 \\
\text { Agg. Pork } \\
\end{array}$ & $\begin{array}{c}\text { Model } 3 \\
\text { Disagg. Pork }\end{array}$ \\
\hline $\begin{array}{l}\text { Aggregate Pork Spending } \\
\text { (in millions of \$) }\end{array}$ & & $\begin{array}{c}0.034 \\
(0.034)\end{array}$ & \\
\hline 2008 Pork Spending & & & $\begin{array}{c}0.735^{* *} \\
(0.280)\end{array}$ \\
\hline 2007 Pork Spending & & & $\begin{array}{l}-0.650 \\
(0.544)\end{array}$ \\
\hline LQ Manufacturing & $\begin{array}{c}-197.07^{* * *} \\
(65.81)\end{array}$ & $\begin{array}{c}-164.54^{* *} \\
(73.15)\end{array}$ & $\begin{array}{c}-168.27^{* *} \\
(71.17)\end{array}$ \\
\hline LQ FIRE & $\begin{array}{r}420.38^{* *} \\
(174.62)\end{array}$ & $\begin{array}{r}445.41^{* *} \\
(176.27)\end{array}$ & $\begin{array}{l}426.18^{* *} \\
(170.04)\end{array}$ \\
\hline Log(Population) & $\begin{array}{c}272.93^{* * *} \\
(82.75)\end{array}$ & $\begin{array}{c}237.43^{* *} \\
(89.79)\end{array}$ & $\begin{array}{l}135.26 \\
(94.23)\end{array}$ \\
\hline Percent under 18 & $\begin{array}{l}-50.83^{*} \\
(27.70)\end{array}$ & $\begin{array}{l}-51.25^{*} \\
(27.69)\end{array}$ & $\begin{array}{c}-56.40^{* *} \\
(26.20)\end{array}$ \\
\hline Percent over 65 & $\begin{array}{c}-72.00 * * \\
(29.05)\end{array}$ & $\begin{array}{c}-69.76 * * \\
(29.12)\end{array}$ & $\begin{array}{c}-69.06 * * \\
(27.36)\end{array}$ \\
\hline Percent Black & $\begin{array}{c}-9.76 * * * \\
(3.16)\end{array}$ & $\begin{array}{c}-10.09 * * * \\
(3.18)\end{array}$ & $\begin{array}{c}-10.54^{* * *} \\
(3.04)\end{array}$ \\
\hline Percent High School & $\begin{array}{c}-33.87^{* * *} \\
(9.92)\end{array}$ & $\begin{array}{c}-33.19 * * * \\
(9.94)\end{array}$ & $\begin{array}{c}-23.07 * * \\
(10.65)\end{array}$ \\
\hline Percent Bachelor's & $\begin{array}{c}18.29 * * \\
(8.38)\end{array}$ & $\begin{array}{c}20.43^{* *} \\
(8.64)\end{array}$ & $\begin{array}{c}18.58^{* *} \\
(8.06)\end{array}$ \\
\hline $\begin{array}{l}\text { Average Wage } \\
\text { (thousands of \$) }\end{array}$ & $\begin{array}{c}-31.33^{* * *} \\
(9.91)\end{array}$ & $\begin{array}{c}-31.44 * * * \\
(9.91)\end{array}$ & $\begin{array}{c}-28.01^{* * *} \\
(9.54)\end{array}$ \\
\hline Right to Work & $\begin{array}{l}94.58^{*} \\
(57.06)\end{array}$ & $\begin{array}{c}117.06^{*} \\
(61.74)\end{array}$ & $\begin{array}{c}110.44^{* *} \\
(57.30)\end{array}$ \\
\hline July Temperature & $\begin{array}{c}72.63 \\
(55.05)\end{array}$ & $\begin{array}{c}73.66 \\
(55.04)\end{array}$ & $\begin{array}{c}124.54^{* *} \\
(56.38)\end{array}$ \\
\hline Constant & $\begin{array}{c}3,721.57 \\
(1,366.36) \\
\end{array}$ & $\begin{array}{c}3,713.78 \\
(1,365.78) \\
\end{array}$ & $\begin{array}{c}3,470.68^{* *} \\
(1,302.21)\end{array}$ \\
\hline $\begin{array}{l}\text { Number of Observations } \\
\text { R-squared } \\
\text { F-Statistic }\end{array}$ & $\begin{array}{c}50 \\
0.573 \\
4.64 * * *\end{array}$ & $\begin{array}{c}50 \\
0.585 \\
4.35^{* * *}\end{array}$ & $\begin{array}{c}50 \\
0.643 \\
4.99 * * *\end{array}$ \\
\hline
\end{tabular}

T-statistics in parentheses: $* * *=1 \%, * *=5 \%, *=10 \%$ significance level

The short term effects, however, are surprisingly large. An additional \$1 million worth of directed expenditures leads to approximately 735 jobs. This amounts to less than $\$ 1,400$ per job created which seems to support the use of pork-barrel spending, even if the jobs are 
temporary. In theory, politicians are able to bring in pork-barrel spending to their state each year in order to offset the job losses associated with older pork-barrel spending.

What is neglected is the fact that pork-barrel spending typically does not cover all of the costs of the project. In some cases, there is a significant amount of spending that must be matched by the state and local governments. In fact, some projects require matching contributions from other agencies in the federal government or private companies. Essentially, pork-barrel spending can be used to close the funding gap for projects. So, even though $\$ 1$ million leads to approximately 735 jobs, this result does not actually mean that \$1 million purchases 735 jobs. All of the results thus far indicate support for the hypothesis that porkbarrel jobs are temporary and can be used for political gain even if there is a significant increase in the quantity of temporary jobs.

\section{OLS Estimates of State Economic Growth Rate Effects}

Next, I repeat the first three, this time using the change in the gross state product (GSP.) The results are given in table 4 . The first estimate, model 4 , attempts to replicate the Blumenthal et. al model. However, several of the independent variables in this regression, such as the location quotient for FIRE industries and several of the demographic variables are no longer significant. In general, the Blumenthal et. al. approach does not work as well for state GSP growth than for employment growth. Regression 5 includes the aggregated pork-barrel spending variable, in addition to the other previously used control variables. In this case, the aggregated pork-barrel spending variable is both positive and significant which indicates that pork-barrel spending can be used to increase the GSP in the long-run even though the increase is relatively small. The independent variables which were significant in the previous treatment, 
such as the location quotient for the FIRE industries, the percentage of the population over 65 years old and the average wage, maintain their expected relationship and statistical significance. Regression 6 removes the aggregated pork-barrel spending variable and replaces them with the two prior years of pork-barrel spending.

Table 4: Non-spatial Change in Gross State Product Regressions (Models 4-6)

\begin{tabular}{|c|c|c|c|}
\hline Variable & $\begin{array}{l}\text { Model } 4 \\
\text { No Pork }\end{array}$ & $\begin{array}{c}\text { Model } 5 \\
\text { Agg. Pork }\end{array}$ & $\begin{array}{c}\text { Model } 6 \\
\text { Disagg. Pork }\end{array}$ \\
\hline $\begin{array}{l}\text { Aggregate Pork Spending } \\
\text { (in millions of \$) }\end{array}$ & & $\begin{array}{c}.046 * * * \\
(0.013)\end{array}$ & \\
\hline 2008 Pork Spending & & & $\begin{array}{c}0.482^{* * *} \\
(0.109)\end{array}$ \\
\hline 2007 Pork Spending & & & $\begin{array}{l}-0.241 \\
(0.212)\end{array}$ \\
\hline LQ Manufacturing & $\begin{array}{c}-70.62 * * \\
(29.86)\end{array}$ & $\begin{array}{l}-26.84 \\
(29.36)\end{array}$ & $\begin{array}{l}-37.30 \\
(27.71)\end{array}$ \\
\hline LQ FIRE & $\begin{array}{l}106.27 \\
(79.23)\end{array}$ & $\begin{array}{c}139.94^{*} \\
(70.74)\end{array}$ & $\begin{array}{l}128.50^{*} \\
(66.20)\end{array}$ \\
\hline Log(Population) & $\begin{array}{c}214.83^{* * *} \\
(37.55)\end{array}$ & $\begin{array}{c}167.06^{* * *} \\
(36.03)\end{array}$ & $\begin{array}{c}126.23 * * * \\
(36.68)\end{array}$ \\
\hline Percent under 18 & $\begin{array}{c}-7.73 \\
(12.57)\end{array}$ & $\begin{array}{c}-8.29 \\
(11.11)\end{array}$ & $\begin{array}{l}-12.32 \\
(10.20)\end{array}$ \\
\hline Percent over 65 & $\begin{array}{l}-16.16 \\
(13.18)\end{array}$ & $\begin{array}{l}-13.13 \\
(11.69)\end{array}$ & $\begin{array}{l}-14.81 \\
(10.65)\end{array}$ \\
\hline Percent Black & $\begin{array}{c}-3.39 * * \\
(1.43)\end{array}$ & $\begin{array}{c}-3.83^{* * *} \\
(1.28)\end{array}$ & $\begin{array}{c}-4.15^{* * *} \\
(1.18)\end{array}$ \\
\hline Percent High School & $\begin{array}{c}-13.81^{* * *} \\
(4.50)\end{array}$ & $\begin{array}{c}-12.90^{* * *} \\
(3.99)\end{array}$ & $\begin{array}{l}-7.78^{*} \\
(4.15)\end{array}$ \\
\hline Percent Bachelor's & $\begin{array}{c}4.21 \\
(3.80)\end{array}$ & $\begin{array}{c}7.09 * * \\
(3.47)\end{array}$ & $\begin{array}{c}5.12 \\
(3.14)\end{array}$ \\
\hline $\begin{array}{l}\text { Average Wage } \\
\text { (thousands of \$) }\end{array}$ & $\begin{array}{l}-5.02 \\
(4.50)\end{array}$ & $\begin{array}{l}-5.17 \\
(3.98)\end{array}$ & $\begin{array}{l}-3.44 \\
(3.71)\end{array}$ \\
\hline Right to Work & $\begin{array}{c}19.59 \\
(25.89)\end{array}$ & $\begin{array}{c}49.85^{* * *} \\
(24.55)\end{array}$ & $\begin{array}{l}38.28^{*} \\
(22.31)\end{array}$ \\
\hline July Temperature & $\begin{array}{l}-34.04 \\
(24.98)\end{array}$ & $\begin{array}{l}-32.66 \\
(22.09)\end{array}$ & $\begin{array}{l}-3.31 \\
(21.95)\end{array}$ \\
\hline Constant & $\begin{array}{c}337.40 \\
(619.98)\end{array}$ & $\begin{array}{c}326.77 \\
(548.13)\end{array}$ & $\begin{array}{c}247.46 \\
(506.97)\end{array}$ \\
\hline Number of Observations & 50 & 50 & 50 \\
\hline R-squared & 0.745 & 0.742 & 0.842 \\
\hline F-Statistic & $10.03 * * *$ & $12.74 * * *$ & $14.79 * * *$ \\
\hline
\end{tabular}

T-statistics in parentheses: ${ }^{* * *}=1 \%, * *=5 \%,{ }^{*}=10 \%$ significance level 
In this case, the \$1 million worth of pork-barrel spending appropriated in 2008 increases gross state product by approximately $\$ 482,000$. This is to be expected since government spending is part of the gross state product. In fact, a \$1 million increase in pork-barrel spending should, at least in theory, increase the gross state product by at least $\$ 1$ million. The fact that this is not observed is likely because the money may not be dispersed all at once; instead, the appropriation and distribution of the federal money can follow two different schedules. The other independent variables which were previously significant remain robust against changes in the pork-barrel spending variable.

\section{Spatial Estimates of State Employment Effects}

Because labor markets tend to be regional in nature, a state-by-state approach is likely to yield biased estimates of the effects of targeted expenditures. Specifically, pork-barrel projects in one state may create spillover effects which increase employment in neighboring states. This is especially likely when projects are done close to a state border. To test for such effects, two additional series of estimates were undertaken using a spatial framework inspired by the nonspatial Blumenthal, Wolman and Hill (2009) model, the change in the total employment level in the state is estimated using the spatial lag model (SLX):

$$
\Delta \text { Total Employment }_{i}=\operatorname{pork}_{i} \alpha+X_{i} \beta+\text { Wpork }_{i} \theta+\varepsilon
$$

Where $X$ is the set of independent variables, pork is the current and lagged pork-barrel spending, $\alpha, \beta$ and $\theta$ are fixed, but unknown coefficients, $W$ pork $_{i}$ is the spatially lagged porkbarrel spending term, $W$ is the five-nearest neighbor weight matrix and $\varepsilon$ is the error term. Blumenthal, Wolman and Hill (2009) model neglected the role of urban, state, and regional interdependence in their work. Table 5 shows the results for the employment estimate. 
Table 5: SLX Employment Results (Models 7-8)

\begin{tabular}{|c|c|c|}
\hline Variable & $\begin{array}{c}\text { Model } 7 \\
\text { Aggregated Pork }\end{array}$ & $\begin{array}{c}\text { Model } 8 \\
\text { Disaggregated Pork }\end{array}$ \\
\hline Total Pork Spending & $\begin{array}{c}0.036 \\
(0.035)\end{array}$ & \\
\hline Total Pork Spending (Spatial Lag) & $\begin{array}{l}-0.016 \\
(0.073)\end{array}$ & \\
\hline 2008 Pork Spending & & $\begin{array}{c}0.826 * * * \\
(0.302)\end{array}$ \\
\hline 2007 Pork Spending & & $\begin{array}{l}-0.761 \\
(0.637)\end{array}$ \\
\hline 2008 Pork Spending (Spatial Lag) & & $\begin{array}{l}0.617 \\
(0.676)\end{array}$ \\
\hline 2007 Pork Spending (Spatial Lag) & & $\begin{array}{l}-1.73 \\
(2.49)\end{array}$ \\
\hline LQ Manufacturing & $\begin{array}{c}-165.32^{* *} \\
(74.19)\end{array}$ & $\begin{array}{c}-167.16^{* *} \\
(74.36)\end{array}$ \\
\hline LQ FIRE & $\begin{array}{l}434.61^{* *} \\
(184.98)\end{array}$ & $\begin{array}{l}431.66^{* *} \\
(173.17)\end{array}$ \\
\hline Log(Population) & $\begin{array}{c}235.81^{* * *} \\
(91.25)\end{array}$ & $\begin{array}{l}110.47 \\
(99.79)\end{array}$ \\
\hline Percent under 18 & $\begin{array}{l}-51.49^{*} \\
(28.08)\end{array}$ & $\begin{array}{l}-51.42^{*} \\
(27.21)\end{array}$ \\
\hline Percent over 65 & $\begin{array}{c}-69.55^{* *} \\
(29.51)\end{array}$ & $\begin{array}{c}-64.92^{* *} \\
(28.17)\end{array}$ \\
\hline Percent Black & $\begin{array}{c}-9.88^{* * *} \\
(3.35)\end{array}$ & $\begin{array}{c}-12.34 * * * \\
(3.67)\end{array}$ \\
\hline Percent High School & $\begin{array}{c}-32.71 * * * \\
(10.29)\end{array}$ & $\begin{array}{l}-21.64^{*} \\
(10.94)\end{array}$ \\
\hline Percent Bachelor's & $\begin{array}{c}-32.71^{* *} \\
(10.29)\end{array}$ & $\begin{array}{c}22.65^{* *} \\
(9.37)\end{array}$ \\
\hline $\begin{array}{l}\text { Average Wage } \\
\text { (thousands of \$) }\end{array}$ & $\begin{array}{c}-30.84^{* * *} \\
(10.39)\end{array}$ & $\begin{array}{c}-27.91 * * * \\
(9.71)\end{array}$ \\
\hline Right to Work & $\begin{array}{l}115.11^{*} \\
(62.59)\end{array}$ & $\begin{array}{c}120.77^{* *} \\
(59.31)\end{array}$ \\
\hline July Temperature & $\begin{array}{c}78.32 \\
(59.52)\end{array}$ & $\begin{array}{c}119.57^{* *} \\
(58.88)\end{array}$ \\
\hline Constant & $\begin{array}{c}3,711.85 \\
(1,383.68)\end{array}$ & $\begin{array}{c}3,316.96 \\
(1,372.44)\end{array}$ \\
\hline $\begin{array}{l}\text { Number of Observations } \\
\text { R-squared } \\
\text { F-Statistic }\end{array}$ & $\begin{array}{c}50 \\
0.586 \\
3.91 * * *\end{array}$ & $\begin{array}{c}50 \\
0.652 \\
4.24^{* * *}\end{array}$ \\
\hline
\end{tabular}

T-statistics in parentheses: ${ }^{* * *}=1 \%, * *=5 \%, *=10 \%$ significance level

The results are similar to the non-spatial results. A $\$ 1$ million increase in pork-barrel spending increases employment in the state which acquired the pork-barrel funding by 
approximately 825 jobs. But, the spatially lagged variables are not significant indicating that pork-barrel appropriations in neighboring states have a negligible impact on employment in the state in question. This result may point to a lack of employment spillovers associated with porkbarrel spending. This is in line with the perception of pork-barrel spending having a geographically concentrated benefit.

The other independent variables also continued to be robust against changes in the model. Even though the spillovers are not detected by the model, they likely do occur on the borders. For example, Montana's five-nearest neighbors are Washington, Idaho, Wyoming, South Dakota and North Dakota. These six states have a total area of approximately 548,000 square miles (or $18 \%$ of the United States total area). It is highly unlikely that there is a significant amount of interstate commuting between these six states. On the other hand, Rhode Island's five-nearest neighbors only account for 73,000 square miles. Employment spillovers are much more likely in this region.

One surprising result is the immediacy of job growth. Initially, I suspected that there would be a lag between the appropriation of the funding and the increase in employment, but the results do not support this. Evidently, contracting for earmarked projects takes place before the money is actually received by the state. ${ }^{5}$

\footnotetext{
${ }^{5}$ Of course, lobbying and other rent-seeking activities occur well before the law is passed. For example, states began to lobby for enticements well before the Patient Care and Affordable Care Act of 2010 was passed. In one case, Senator Bernie Sanders obtained $\$ 10$ billion (with a "b") to be used for the construction of new community health centers (Frates 2009) before the law was passed. The same holds true for the infrastructure projects associated with the American Reinvestment and Recovery Act of 2009 (ARRA.) Even before the bill was passed or funds allocated, states competed for the funds that would be earmarked for state-specific projects. Barack Obama referred to this as funding "shovel-ready" jobs.
} 


\section{Spatial Estimates of State Economic Growth Rate Effects}

Table 6 displays the results for the spatial change in gross state product. Unlike the employment estimates, there is some evidence of spatial spillover. Specifically, there is some evidence of the backwash effect as an increase in neighboring states' appropriation of porkbarrel spending may lead to a decrease in gross state product for the state of interest. Again, the other independent variables remain robust to changes in the structure of the model.

\section{Implications of Estimates}

The above results provide support for the hypothesis that earmarked and other targeted spending can be used to increase employment. The results also suggest that the job effects are temporary. While this may seem like a downside of pork-barrel spending, it actually provides advantages for incumbents. Because these jobs eventually disappear, the incumbent must continue to secure money to bring in new jobs. This benefits the incumbent because it allows them to continually attach their name to job-creating legislation. A legislator may have a difficult time taking credit for maintaining the job level but will have a much easier time taking credit for job created using pork-barrel spending. 
Table 6: SLX GSP Results (Models 9-10)

\begin{tabular}{|c|c|c|}
\hline Variable & $\begin{array}{c}\text { Model } 9 \\
\text { Aggregated Pork }\end{array}$ & $\begin{array}{c}\text { Model } 10 \\
\text { Disaggregated Pork }\end{array}$ \\
\hline Total Pork Spending & $\begin{array}{c}0.053^{* * *} \\
(0.128)\end{array}$ & \\
\hline Total Pork Spending (Spatial Lag) & $\begin{array}{c}-0.071^{* *} \\
(0.027)\end{array}$ & \\
\hline 2008 Pork Spending & & $\begin{array}{c}0.416^{* * *} \\
(0.112)\end{array}$ \\
\hline 2007 Pork Spending & & $\begin{array}{l}-0.023 \\
(0.237)\end{array}$ \\
\hline 2008 Pork Spending (Spatial Lag) & & $\begin{array}{l}-0.417 \\
(0.252)\end{array}$ \\
\hline 2007 Pork Spending (Spatial Lag) & & $\begin{array}{c}0.186 \\
(0.926)\end{array}$ \\
\hline LQ Manufacturing & $\begin{array}{l}-30.24 \\
(27.29)\end{array}$ & $\begin{array}{l}-29.01 \\
(27.67)\end{array}$ \\
\hline LQ FIRE & $\begin{array}{c}93.30 \\
(68.05)\end{array}$ & $\begin{array}{l}130.02^{*} \\
(64.43)\end{array}$ \\
\hline Log(Population) & $\begin{array}{c}160.04 * * * \\
(33.57)\end{array}$ & $\begin{array}{c}145.09 * * \\
(37.13)\end{array}$ \\
\hline Percent under 18 & $\begin{array}{c}-9.32 \\
(10.33)\end{array}$ & $\begin{array}{l}-16.05 \\
(10.12)\end{array}$ \\
\hline Percent over 65 & $\begin{array}{l}-12.23 \\
(10.86)\end{array}$ & $\begin{array}{l}-17.38 \\
(10.48)\end{array}$ \\
\hline Percent Black & $\begin{array}{c}-2.92^{* *} \\
(1.23)\end{array}$ & $\begin{array}{c}-3.22^{* *} \\
(1.37)\end{array}$ \\
\hline Percent High School & $\begin{array}{c}-10.83^{* * *} \\
(3.79)\end{array}$ & $\begin{array}{c}-8.42^{* *} \\
(4.07)\end{array}$ \\
\hline Percent Bachelor's & $\begin{array}{c}3.69 \\
(3.47)\end{array}$ & $\begin{array}{c}2.13 \\
(3.49)\end{array}$ \\
\hline $\begin{array}{l}\text { Average Wage } \\
\text { (thousands of \$) }\end{array}$ & $\begin{array}{l}-2.57 \\
(3.82)\end{array}$ & $\begin{array}{l}-3.22 \\
(3.61)\end{array}$ \\
\hline Right to Work & $\begin{array}{l}41.40^{*} \\
(23.02)\end{array}$ & $\begin{array}{c}32.38 \\
(22.07)\end{array}$ \\
\hline July Temperature & $\begin{array}{l}-12.53 \\
(21.90)\end{array}$ & $\begin{array}{c}6.11 \\
(21.90)\end{array}$ \\
\hline Constant & $\begin{array}{c}318.90 \\
(509.02) \\
\end{array}$ & $\begin{array}{c}436.62 \\
(510.70) \\
\end{array}$ \\
\hline $\begin{array}{l}\text { Number of Observations } \\
\text { R-squared } \\
\text { F-Statistic }\end{array}$ & $\begin{array}{c}50 \\
0.837 \\
14.16^{* * *}\end{array}$ & $\begin{array}{c}50 \\
0.859 \\
13.85^{* * *}\end{array}$ \\
\hline
\end{tabular}

T-statistics in parentheses: ${ }^{* * *}=1 \%, * *=5 \%, *=10 \%$ significance level 


\subsection{Conclusions}

This paper provides evidence that earmarked and other targeted spending has local economic effects on employment and economic development, albeit temporary ones. By using an established model by Blumenthal, Wolman and Hall (2009), I was able to model factors which influenced the seven-year change in total employment and seven-year change in gross state product between 2001-2008. The main addition to the model was a pork-barrel spending variable. When a seven-year aggregated pork-barrel spending variable is used, a \$1 million increase in pork-barrel spending creates less than 40 jobs. But, when lagged pork-barrel spending is used, an additional $\$ 1$ million dollars of pork-barrel spending increases employment by nearly 750 jobs in the following year. But, after the following years, most of those jobs disappear. This is likely due to the prominence of construction and construction-related jobs. Jobs which did remain after the first four years tended to disappear within ten years of the original funding. Similarly, the gross state product increases by around $\$ 482,000$ in the year following the \$1 million acquisition of the earmark; yet, just as was the case with changes in employment, the impacts on the gross state product were short-lived.

When a spatial lag model $(S L X)$ is used, there is no evidence that pork-barrel spending influences employment in surrounding states. The results mirror the non-spatial regressions which indicate a quick increase employment followed by a reduction only a few years later. This gives evidence to the belief that pork-barrel spending generates only spatially concentrated benefits. Specifically, pork-barrel spending is only used to benefits in the Senator's state without any regard to the costs borne by the other states (and the rest of the world.) In 
addition, the independent control variables are also robust against changes in the structure of the model.

Ultimately, there is evidence that pork-barrel spending can be used for countercyclical policies although not for promoting long term economic growth or unemployment. The fact that such programs are adopted in good times and bad suggests that pork-barrel spending is utilized by politicians for short-term gains in hopes of increasing their chances of being reelected, rather than to promote long term economic objectives.

While this paper focuses on employment and economic growth, it should be noted that there are other benefits to the use of pork-barrel spending. For example, pork-barrel spending that funds a new museum may marginally increase the employment level in an area after it is built, but the main purpose of the museum is to provide an amenity for state residents. Whether the employment effects or the amenity effects of targeted expenditures have the greater effect on incumbent reelection prospects is left for future work.

\subsection{Appendix: Alternative Time Periods}

\section{3-Year Changes in Employment}

Anytime a specific timeframe is selected, questions arise regarding whether the effects detected are due to the independent variables or if the relationship is merely a consequence of some lurking variable. In the original paper, I considered the change in employment from 2001 to 2008. In this appendix, I will use a three-year rolling average from 2001 to 2008 . The major difference in this estimation is that the pork-barrel spending for a total of three years is used: the pork-barrel spending from the year in question as well as the pork-barrel spending from the previous two years. In addition, I also use the aggregate spending from the three years. While 
the results do not match exactly, they do give further evidence to the hypothesis that employment is created through pork-barrel spending. Table 7 replicates regressions 1-3 with the only difference being the four-year time period.

Table 7: Non-spatial Change in Total Employment Regressions (Models 11-13)

\begin{tabular}{|c|c|c|c|}
\hline Variable & $\begin{array}{l}\text { Model } 11 \\
\text { No Pork }\end{array}$ & $\begin{array}{l}\text { Model } 12 \\
\text { Agg. Pork }\end{array}$ & $\begin{array}{l}\text { Model } 13 \\
\text { Disagg. Pork }\end{array}$ \\
\hline $\begin{array}{l}\text { Aggregate Pork Spending } \\
\text { (in millions of \$) }\end{array}$ & & $\begin{array}{c}0.102 * * * \\
(0.016)\end{array}$ & \\
\hline Pork Spending in Year $t$ & & & $\begin{array}{c}0.088 \\
(0.079)\end{array}$ \\
\hline Pork Spending in Year $t-1$ & & & $\begin{array}{c}0.346 * * * \\
(0.102)\end{array}$ \\
\hline Pork Spending in Year $t-2$ & & & $\begin{array}{c}-0.263 * * * \\
(0.079)\end{array}$ \\
\hline LQ Manufacturing & $\begin{array}{c}-152.40 * * * \\
(25.83)\end{array}$ & $\begin{array}{c}-85.55^{* * *} \\
(26.08)\end{array}$ & $\begin{array}{c}-134.33^{* * *} \\
(27.49)\end{array}$ \\
\hline LQ FIRE & $\begin{array}{c}145.12 * * \\
(58.94)\end{array}$ & $\begin{array}{c}246.39 * * * \\
(56.79)\end{array}$ & $\begin{array}{c}180.59 * * * \\
(57.41)\end{array}$ \\
\hline Log(Population) & $\begin{array}{c}320.77^{* * *} \\
(29.04)\end{array}$ & $\begin{array}{c}265.43 * * * \\
(28.23)\end{array}$ & $\begin{array}{c}297.54^{* * *} \\
(31.31)\end{array}$ \\
\hline Percent under 18 & $\begin{array}{c}4.24 \\
(9.80)\end{array}$ & $\begin{array}{l}-7.72 \\
(9.26)\end{array}$ & $\begin{array}{c}3.18 \\
(9.45)\end{array}$ \\
\hline Percent over 65 & $\begin{array}{l}-9.70 \\
(9.85)\end{array}$ & $\begin{array}{l}-14.40 \\
(9.14)\end{array}$ & $\begin{array}{l}-9.05 \\
(9.44)\end{array}$ \\
\hline Percent Black & $\begin{array}{c}-7.62 * * * \\
(1.25)\end{array}$ & $\begin{array}{c}-8.19 * * * \\
(1.16)\end{array}$ & $\begin{array}{c}-7.68 * * * \\
(1.21)\end{array}$ \\
\hline Percent High School & $\begin{array}{c}-22.30 * * * \\
(3.64)\end{array}$ & $\begin{array}{c}-20.87^{* * *} \\
(3.38)\end{array}$ & $\begin{array}{c}-22.39 * * * \\
(3.50)\end{array}$ \\
\hline Percent Bachelor's & $\begin{array}{c}3.85 \\
(3.30)\end{array}$ & $\begin{array}{c}9.20 * * * \\
(3.16)\end{array}$ & $\begin{array}{c}6.56^{* *} \\
(3.22)\end{array}$ \\
\hline $\begin{array}{l}\text { Average Wage } \\
\text { (thousands of \$) }\end{array}$ & $\begin{array}{l}-0.000 \\
(0.003)\end{array}$ & $\begin{array}{c}-0.003 \\
(0.003)\end{array}$ & $\begin{array}{l}-0.003 \\
(0.003)\end{array}$ \\
\hline Right to Work & $\begin{array}{c}81.09 * * * \\
(22.87)\end{array}$ & $\begin{array}{c}133.48 * * * \\
(22.69)\end{array}$ & $\begin{array}{c}93.72 * * * \\
(23.87)\end{array}$ \\
\hline July Temperature & $\begin{array}{c}-43.17^{* *} \\
(21.96)\end{array}$ & $\begin{array}{l}-38.92 * \\
(20.33)\end{array}$ & $\begin{array}{c}-43.23^{* *} \\
(21.05)\end{array}$ \\
\hline Constant & $\begin{array}{c}-42.49 \\
(480.46)\end{array}$ & $\begin{array}{c}229.01 \\
(446.59) \\
\end{array}$ & $\begin{array}{c}42.93 \\
(463.79) \\
\end{array}$ \\
\hline $\begin{array}{l}\text { Number of Observations } \\
\text { R-squared } \\
\text { F-Statistic }\end{array}$ & $\begin{array}{c}250 \\
0.625 \\
36.08 * * *\end{array}$ & $\begin{array}{c}250 \\
0.680 \\
42.04^{* * *}\end{array}$ & $\begin{array}{c}250 \\
0.660 \\
32.61 * * *\end{array}$ \\
\hline
\end{tabular}

T-statistics in parentheses: $* * *=1 \%, * *=5 \%, *=10 \%$ significance level 
The main difference is this case is that the changes are not immediate. Furthermore, the impacts are not as significant. In any case, the same general transitory effects are present. In addition, the other control variables are not as robust. This is likely due to the shorter time period. One of the hypotheses of the original work is that many of these factors impact employment over the long-run; but using a three-year time period may not fully capture the impact of the control variables.

When multiple time periods are used, additional econometric techniques become available. Specifically, I utilize a fixed-effect panel regression with time-based binary variables. The Hausman test indicated that a fixed-effect regression should be used. The results of the Hausman tests are given below.

\section{Table 8: Hausman Test Results I}

\begin{tabular}{|c|c|}
\hline Regression & Chi-Squared Statistic \\
\hline No Pork-Barrel Spending & $31.74^{* * *}$ \\
Aggregated Pork-Barrel Spending & $28.61^{* * *}$ \\
Yearly Pork-Barrel Spending & $35.23^{* * *}$ \\
\hline$* * *=1 \%, * *=5 \%, *=10 \%$ significance level
\end{tabular}

$* * *=1 \%, * *=5 \%, *=10 \%$ significance level

I replicate the original three regressions once again only within the fixed-effect panel regression framework. Due to the inclusion of state fixed effects, the population, right to work and July temperature variables are excluded. In addition, I include the yearly binary variables. The results are given below in table 9. 
Table 9: Panel Change in Total Employment Regressions (Models 11-13)

\begin{tabular}{|c|c|c|c|}
\hline Variable & $\begin{array}{l}\text { Model } 14 \\
\text { No Pork }\end{array}$ & $\begin{array}{l}\text { Model } 15 \\
\text { Agg. Pork } \\
\end{array}$ & $\begin{array}{c}\text { Model } 16 \\
\text { Disagg. Pork }\end{array}$ \\
\hline $\begin{array}{l}\text { Aggregate Pork Spending } \\
\text { (in millions of \$) }\end{array}$ & & $\begin{array}{l}-0.012 \\
(0.058)\end{array}$ & \\
\hline Pork Spending in Year $t$ & & & $\begin{array}{l}0.137^{*} \\
(0.077)\end{array}$ \\
\hline Pork Spending in Year $t-1$ & & & $\begin{array}{c}-0.271 * * * \\
(0.079)\end{array}$ \\
\hline Pork Spending in Year $t-2$ & & & $\begin{array}{c}0.007 \\
(0.089)\end{array}$ \\
\hline LQ Manufacturing & $\begin{array}{c}1.22 \\
(72.57)\end{array}$ & $\begin{array}{c}2.06 \\
(72.88)\end{array}$ & $\begin{array}{l}-5.32 \\
(69.42)\end{array}$ \\
\hline LQ FIRE & $\begin{array}{l}247.99 * \\
(131.32)\end{array}$ & $\begin{array}{l}249.54^{*} \\
(131.87)\end{array}$ & $\begin{array}{l}293.65^{* *} \\
(125.80)\end{array}$ \\
\hline Percent under 18 & $\begin{array}{c}47.48^{* *} \\
(19.62)\end{array}$ & $\begin{array}{c}47.41^{* *} \\
(19.68)\end{array}$ & $\begin{array}{c}55.48^{* * *} \\
(18.79)\end{array}$ \\
\hline Percent over 65 & $\begin{array}{c}19.51 \\
(44.59)\end{array}$ & $\begin{array}{c}18.63 \\
(44.92)\end{array}$ & $\begin{array}{c}25.35 \\
(42.66)\end{array}$ \\
\hline Percent Black & $\begin{array}{c}-130.13^{* * *} \\
(36.22)\end{array}$ & $\begin{array}{c}-129.27 * * * \\
(36.56)\end{array}$ & $\begin{array}{c}-119.49 * * * \\
(35.00)\end{array}$ \\
\hline Percent High School & $\begin{array}{c}21.47^{* *} \\
(10.44)\end{array}$ & $\begin{array}{l}21.54 * * \\
(10.46)\end{array}$ & $\begin{array}{c}18.08^{* *} \\
(9.97)\end{array}$ \\
\hline Percent Bachelor's & $\begin{array}{l}-16.42 \\
(10.98)\end{array}$ & $\begin{array}{l}-16.77 \\
(11.14)\end{array}$ & $\begin{array}{l}-16.24 \\
(10.58)\end{array}$ \\
\hline $\begin{array}{l}\text { Average Wage } \\
\text { (thousands of } \$ \text { ) }\end{array}$ & $\begin{array}{l}0.012 \\
(0.015)\end{array}$ & $\begin{array}{c}0.012 \\
(0.016)\end{array}$ & $\begin{array}{c}0.011 \\
(0.015)\end{array}$ \\
\hline Year 2005 & $\begin{array}{c}5.07 \\
(22.42)\end{array}$ & $\begin{array}{c}4.73 \\
(22.54)\end{array}$ & $\begin{array}{c}-4.57 \\
(21.59)\end{array}$ \\
\hline Year 2006 & $\begin{array}{l}90.77^{* *} \\
(40.34)\end{array}$ & $\begin{array}{l}89.60 * * \\
(40.83)\end{array}$ & $\begin{array}{l}80.93 * * \\
(39.33)\end{array}$ \\
\hline Year 2007 & $\begin{array}{l}61.88 \\
(57.41)\end{array}$ & $\begin{array}{l}58.58 \\
(59.79)\end{array}$ & $\begin{array}{l}71.45 \\
(56.88)\end{array}$ \\
\hline Year 2008 & $\begin{array}{c}76.09 \\
(78.11)\end{array}$ & $\begin{array}{c}72.26 \\
(80.54)\end{array}$ & $\begin{array}{c}26.23 \\
(77.86)\end{array}$ \\
\hline Constant & $\begin{array}{l}-2,092.87 \\
(1,244.02) \\
\end{array}$ & $\begin{array}{l}-2,091.73 \\
(1,247.21) \\
\end{array}$ & $\begin{array}{l}-2,165.71 \\
(1,184.86) \\
\end{array}$ \\
\hline $\begin{array}{l}\text { Number of Observations } \\
\text { R-squared }\end{array}$ & $\begin{array}{c}250 \\
0.423\end{array}$ & $\begin{array}{l}250 \\
0.423\end{array}$ & $\begin{array}{c}250 \\
0.486\end{array}$ \\
\hline $\begin{array}{l}\text { F-Statistic } \\
\text { Dependent Variables }\end{array}$ & $11.48^{* * *}$ & $10.55^{* * *}$ & $11.64^{\mathrm{NOF}}$ \\
\hline
\end{tabular}

T-statistics in parentheses: $* * *=1 \%, * *=5 \%, *=10 \%$ significance level

Quantitatively, the results are not as robust. Some of this is likely due to the fixed-effects picking-up some of the variance caused by the control variables. Also, as previously mentioned, 
this model was specified to examine long-run changes in employment and is not completely suitable for only three-year changes.

\section{The Special Case of the 2008 Recession and Stimulus}

In addition to a three-year change in employment, I also include a nine-year change in employment. As mentioned, I am unable to go any further back than 2001 due to availability of data. Further, starting in 2011, a moratorium was issued on pork-barrel spending which creates data problems from 2011 and on. Therefore, the longest possible time period is 2001-2010. A very serious issue arises when studying this time period: the 2008 'Great Recession' and corresponding stimulus bill. When considering the change in employment from 2001 to 2010, the extreme job losses from 2008-2010 are included and are not indicative of the employment experiences over the entire time period. Further, the extreme stimulus spending (including the $\$ 787$ billion American Recovery and Reinvestment Act) is atypical. Therefore, the results from this time period cannot be used to generalize the impacts of pork-barrel spending on employment.

I repeat the original three regressions using the nine-year change in employment. The results are reported in Table 10.

The estimates in this model are similar to the previous results with some differences. First of all, the magnitude of the job gains (and subsequent losses) are far greater. This is likely due to the fact that employment fell so much during the financial crisis. Second of all, the transitory job losses seem to be delayed with job losses delayed for three years. In any case, these results still adhere to the general conclusion that pork-barrel spending does indeed create jobs but these jobs do not seem to be permanent. Therefore, legislators do have an incentive to pursue 
pork-barrel spending in order to increase employment in the short-run, but the corresponding employment increases will not persist. Thus, if the legislator intends to continue to stimulate employment, they must provide their state with a continual flow of pork-barrel money.

Table 10: Change in Total Employment Regressions (Models 17-19)

\begin{tabular}{|c|c|c|c|}
\hline Variable & $\begin{array}{l}\text { Model } 17 \\
\text { No Pork }\end{array}$ & $\begin{array}{l}\text { Model } 18 \\
\text { Agg. Pork }\end{array}$ & $\begin{array}{l}\text { Model } 19 \\
\text { Disagg. Pork }\end{array}$ \\
\hline $\begin{array}{l}\text { Aggregate Pork Spending } \\
\text { (in millions of \$) }\end{array}$ & & $\begin{array}{l}0.09 * * \\
(2.35)\end{array}$ & \\
\hline $\begin{array}{l}2010 \text { Pork Spending } \\
\text { (in millions of \$) }\end{array}$ & & & $\begin{array}{l}1.46^{* * *} \\
(3.41)\end{array}$ \\
\hline 2009 Pork Spending & & & $\begin{array}{l}0.71 \\
(0.78)\end{array}$ \\
\hline 2008 Pork Spending & & & $\begin{array}{l}-0.15 \\
(-0.33)\end{array}$ \\
\hline 2007 Pork Spending & & & $\begin{array}{l}-0.80^{* *} \\
(-2.54)\end{array}$ \\
\hline LQ Manufacturing & $\begin{array}{l}-299.6^{* * *} \\
(2.61)\end{array}$ & $\begin{array}{l}-190.2^{*} \\
(-1.84)\end{array}$ & $\begin{array}{l}-247.3^{* *} \\
(-2.54)\end{array}$ \\
\hline LQ FIRE & $\begin{array}{l}678.9 * * \\
(2.61)\end{array}$ & $\begin{array}{l}774.0 * * * \\
(3.11)\end{array}$ & $\begin{array}{l}734.7 * * * \\
(3.16)\end{array}$ \\
\hline Log(Population) & $\begin{array}{l}560.6^{* * *} \\
(4.53)\end{array}$ & $\begin{array}{l}434.5^{* * *} \\
(3.37)\end{array}$ & $\begin{array}{l}406.9^{* * *} \\
(3.01)\end{array}$ \\
\hline Percent under 18 & $\begin{array}{l}-80.8^{* *} \\
(-2.08)\end{array}$ & $\begin{array}{l}-84.8^{* *} \\
(-2.30)\end{array}$ & $\begin{array}{l}-92.2^{* * *} \\
(-2.72)\end{array}$ \\
\hline Percent over 65 & $\begin{array}{l}-121.0 * * * \\
(-2.91)\end{array}$ & $\begin{array}{l}-117.9 * * * \\
(-2.99)\end{array}$ & $\begin{array}{l}-112.0^{* * *} \\
(-3.10)\end{array}$ \\
\hline Percent Black & $\begin{array}{l}-14.1 * * * \\
(-3.18)\end{array}$ & $\begin{array}{l}-14.9 * * * \\
(-3.54)\end{array}$ & $\begin{array}{l}-13.6 * * * \\
(-3.25)\end{array}$ \\
\hline Percent High School & $\begin{array}{l}-61.5 * * * \\
(-4.15)\end{array}$ & $\begin{array}{l}-58.1 * * * \\
(-4.13)\end{array}$ & $\begin{array}{l}-43.4^{* * *} \\
(2.93)\end{array}$ \\
\hline Percent Bachelor's & $\begin{array}{l}31.2^{* *} \\
(2.49)\end{array}$ & $\begin{array}{l}37.1 * * * \\
(3.06)\end{array}$ & $\begin{array}{l}24.2^{* * *} \\
(2.06)\end{array}$ \\
\hline $\begin{array}{l}\text { Average Wage } \\
\text { (thousands of \$) }\end{array}$ & $\begin{array}{l}-49.5^{* * *} \\
(-3.34)\end{array}$ & $\begin{array}{l}-50.0 * * * \\
(-3.57)\end{array}$ & $\begin{array}{l}-42.8^{* * *} \\
(-3.31)\end{array}$ \\
\hline Right to Work & $\begin{array}{l}163.3^{*} \\
(1.92)\end{array}$ & $\begin{array}{l}236.3^{* * *} \\
(2.75)\end{array}$ & $\begin{array}{l}200.1^{* *} \\
(2.58)\end{array}$ \\
\hline Constant & $\begin{array}{l}5,814^{* * *} \\
(2.90) \\
\end{array}$ & $\begin{array}{l}5,884^{* * *} \\
(3.10)\end{array}$ & $\begin{array}{l}5,119^{* * *} \\
(2.92) \\
\end{array}$ \\
\hline Number of Observations & 50 & 50 & 50 \\
\hline R-squared & 0.65 & 0.70 & 0.778 \\
\hline F-Statistic & $7.39 * * *$ & $8.00 * * *$ & $8.64 * * *$ \\
\hline
\end{tabular}

T-statistics in parentheses: $* * *=1 \%, * *=5 \%, *=10 \%$ significance level 


\title{
Chapter 3: The Impact of Pork-Barrel Spending on Incumbent Fundraising
}

\begin{abstract}
Pork-barrel spending is the use of federal money for localized projects which typically yield only a narrow geographic benefit. It is a commonly held belief that politicians utilize this spending to improve their chances of re-election. One way an incumbent can increase their chances of re-election is through increased fundraising. This paper investigates whether incumbents are able to use pork-barrel spending to bolster their campaign contributions. I find that for every $\$ 1$ million of pork-barrel spending, incumbents are able to increase their campaign contributions by approximately $\$ 17,000$. But, this effect is only present when the incumbent properly times the project. I also find that general federal appropriations do not have the same impact. These results support the belief that legislators knowingly use pork-barrel spending for their own personal benefit.
\end{abstract}

\subsection{Introduction}

Incumbents can use a variety of strategies in their quest for reelection. He or she can press for legislation that advances the general interest of voters in the district. They can also attempt to increase the funds available for campaigning for reelection. Information is costly for voters, so much of their efforts will be to subsidize information about themselves and their rivals to voters. News accounts suggest that candidates spend a good deal of time attempting to raise money for their next campaign. One class of policies has the potential to both benefit voters in a given district and simultaneously provide voters with information about the incumbent's ability to provide benefits to them, namely targeted spending in their electoral districts. Incumbents can take credit for steering federal money into their home districts, and the economic benefits generated and campaign contributions from those positively impacted by the federal money both tend to improve their prospects for reelection. Bringing home "the bacon" is also a strategy that their rivals cannot take advantage of. 
Pork-barrel projects thus can benefit the incumbent through three channels. First, porkbarrel spending can give a legislator's constituents a reason to re-elect the legislator as porkbarrel projects are typically visible and useful to the constituents. Second, as shown in the previous chapter of this dissertation, pork-barrel spending can result in improved economic conditions. If a constituent's life is indirectly improved through a pork-barrel project, that citizen is more likely to cast a vote for the incumbent. Third, pork-barrel projects that benefit specific concentrated groups will encourage campaign contributions from said groups. All three of these effects increase the likelihood that an incumbent is re-elected.

This paper focuses on the third channel. The main goal of this chapter is to estimate the effect that pork-barrel spending has on fundraising. Three hypotheses are tested: first that pork-barrel spending has an impact on an incumbent's ability to fundraise, second that the timing of the pork-barrel appropriations matter, and third that general federal appropriations do not have the same impact on fundraising that pork-barrel spending does.

\subsection{District Targeted Federal Spending and Reelection}

It is clear that if pork barrel spending can increase campaign contributions, that by itself may be a sufficient reason to seek it. A long series of studies have shown that campaign expenditures are directly related to success in an election (Palda 1973; Welch 1974; Palda 1975; Dawson and Zinser 1976; Welch 1976; Samuels 2002; Stratmann 2013). Therefore, incumbents have an incentive to do whatever is in their power to secure additional campaign contributions. The question addressed below is whether pork barrel spending tends to increase campaign contributions. 
There are several reasons why this might be the case. Firms that profit from pork barrel spending may contribute to campaigns or encourage their employees to contribute as a method of thanking the candidate or, but increasing their chance of reelection, increasing the probability that additional profits from pork will come their way. Until recent Supreme Court decisions, corporations could only indirectly directly contribute to candidates running for federal office, but they could provide financial and other support to political action committees (PACS).$^{6}$

The link between campaign contributions and corporate gains is largely anecdotal in the United States (Stratmann 1995; Milyo 1999); however, empirical evidence of this effect has been shown in other countries such as Brazil (Boas, Hidalgo et al. 2014). For example, in 1993, individual members of the Brazilian congressional Joint Budget Committee accepted kickbacks of up to $3 \%$ of a project's value in compensation for their assistance in funding approval (Krieger, Rodrigues et al. 1994; Boas, Hidalgo et al. 2014). ${ }^{7}$ Even more recently, Andrade Gutierrez, one of the largest construction companies in Brazil, increased its contributions in municipal elections from nearly $\$ 75,000$ to $\$ 37.1$ million. During the same time, the company was awarded nearly $\$ 3$ billion in construction contracts associated with the 2014 World Cup (Payne 2014).

Pinpointing the relationship between corp orate gains and fundraising in the United States has been problematic for many reasons. First, due to campaign finance laws, corporations can

${ }^{6}$ Of course, this link is likely to exist only in cases in which incumbents are likely to win. There is little incentive to reward a candidate that has delivered in the past if they are not expected to be able to do so in the future (Wilhite and Theilmann 1987). However, all incumbents except those plagued by scandals have a high probability of reelection.

${ }^{7}$ Once corporate campaign contributions were legalized in Brazil, the kickbacks were simply paid through campaign contributions instead of previously under-the-table payments. 
only donate money to PACs which then use the money to support a politician or issue. Records of PAC contributions are less detailed than those to candidates and therefore it is difficult to measure corporate efforts to support incumbents. Moreover, the links between corporate gains and public policy is rarely obvious. ${ }^{8}$

Although it tends to be difficult to link corporate profits to national programs, this problem is reduced for the case of targeted expenditures. Pork may be presumed to have the greatest effect on the profits of firms in the district receiving the expenditures. Potential donors benefit both from contracts to produce the services provided, necessary infrastructure for those projects, and indirectly through expenditures by firms and their employees in the district of interest. Chapter 2, for example, demonstrates that pork barrel spending tends to reduce district unemployment.

Of course, legislators may also attempt to use general appropriations to their advantage. General programs are typically much larger than targeted expenditures. However, legislators have a more difficult time claiming credit for general government spending. This is both because a single representative's vote is rarely decisive and because many general federal appropriations are formula-based so individual legislators have very little control over the amount of money that each state receives (Lee 2003). As a consequence, large federal programs are very difficult to change in a manner that generates state or district specific benefits.

\footnotetext{
${ }^{8}$ The productivity of campaign contributions may also be difficult to assess. For example, the presence of many small contributors dilutes the significance of other larger donations (Ansolabehere, de Figueiredo, and Snyder 2003).
} 


\subsection{The Fundraising Effects of Pork Are Understudied}

Given the extensive research conducted on political fundraising and the effects of campaign spending, there has been surprisingly little research on the effects of pork-barrel spending on campaign contributions. David Samuels (2002) finds that increased pork-barrel spending leads to an increase in incumbent fundraising, all else equal. The additional campaign contributions are then used to increase the likelihood of reelection. However, his work does not address the mechanism through which pork barrel spending increases prospects for electoral success. This paper investigates whether pork barrel spending tends to increase incumbent campaign contributions

While Samuels (2002) posits that pork-barrel spending increases fundraising, Stratmann (2013) contends that fundraising tends to increase pork. The results of this paper suggest that Stratmann has misidentified the relationship and that Samuels analysis is more descriptive. My study differs from Stratmann's work in that it focuses on the Senate rather than the House of Representatives. Senators normally have more direct effect over public policies, including pork, than members of the House. Their longer terms also suggest that they will benefit from pork that has beneficial effects only with a significant lag. Moreover, it is likely that expenditures targeted at specific states generate benefits that are concentrated in states, rather than spread out across districts through effects of sub-contracting, commuting, and shopping across district boundaries.

There is, however, also one significant disadvantage associated with a state-level analysis instead of a district-level study. There are two Senators per state elected at-large. Therefore, it is impossible to separate the effect that each Senator has on targeted spending in their states. 
This implies that the Samuels and Stratmann's framework can be applied at the state-level only after several modifications are adopted. ${ }^{9}$

\section{Model, Data and Estimation Strategy}

I use a fundraising model based on Samuels (2002), Krebs (2001) and Bonneau (2007) for the purposes of estimation. The Samuels (2002) model estimates the percentage of campaign finance in a Brazilian state based on factors such as previous electoral success, number of terms served and party leadership. In addition, Krebs (2001) analyzes fundraising in city council elections and Bonneau (2007) addresses the determinants of fundraising in state Supreme Court elections. While the last two papers are not performed at the federal level, many of the determinants still apply regardless of the level of government being discussed.

This study extends the Samuels (2002) paper and complements Stratmann (2013) approach in the following ways. First, the present study focuses on United States election cycles from 2004 to 2012, rather than a single election. Second, unlike the Samuels (2002) paper, this paper examines the United States. Finally, this study focuses on the Senate unlike the Krebs (2001), Bonneau (2007) and Stratmann (2013) papers which examine other levels of government.

\section{Data}

Data on the incumbent was collected for all Senators vying for re-election from 2004-2012. Data on pork-barrel spending are taken from the Citizens Against Government Waste data set. The pork-barrel spending variable takes two different forms. The first variable measures the total amount of pork-barrel spending appropriated in the Senator's state during their six-year

\footnotetext{
${ }^{9}$ Another possible disadvantage is that spatial estimation techniques are unlikely to reveal coalition or logrolling effects because incentives to do so are weaker. Fewer benefits are likely to be realized by adjacent states than adjacent Congressional districts, because of differences in size and distance.
} 
term in millions of dollars. The second uses a set of annual pork-barrel spending variables instead of the original aggregated form. The pork-barrel spending appropriated to a state is linked to state electoral cycles, rather than years, per se. For instance, if a Senator was up for re-election in 2008 , I compute the amount of pork-barrel spending that went to the state from 2003-2008, both annually and in aggregate. This permits me to determine if when the porkbarrel money was appropriated with electoral cycles in has a subsequent impact on campaign donations. Specifically, I test to determine if pork-barrel spending appropriated in the years before a Senator stands for reelection impacts fundraising. Because Senate terms are six years long, data from 1999-2012 is used. Since it is impossible to distinguish between the individual efforts of each Senator, the total amount of pork-barrel spending appropriated by the state is used. There are eight years of pork barrel spending data available at the state-level, but only three years of data at the district level.

I hypothesize that an election cycle will be present in pork-barrel spending. Specifically, pork-barrel spending will spike every two years in concert with the federal elections. Even though a Senator is only elected every six years, other Senators will attempt to appropriate pork-barrel spending for their own use. A graphical representation of the data shows the existence of an election cycle with pork-barrel spending spiking during election years. This graph is shown below. 


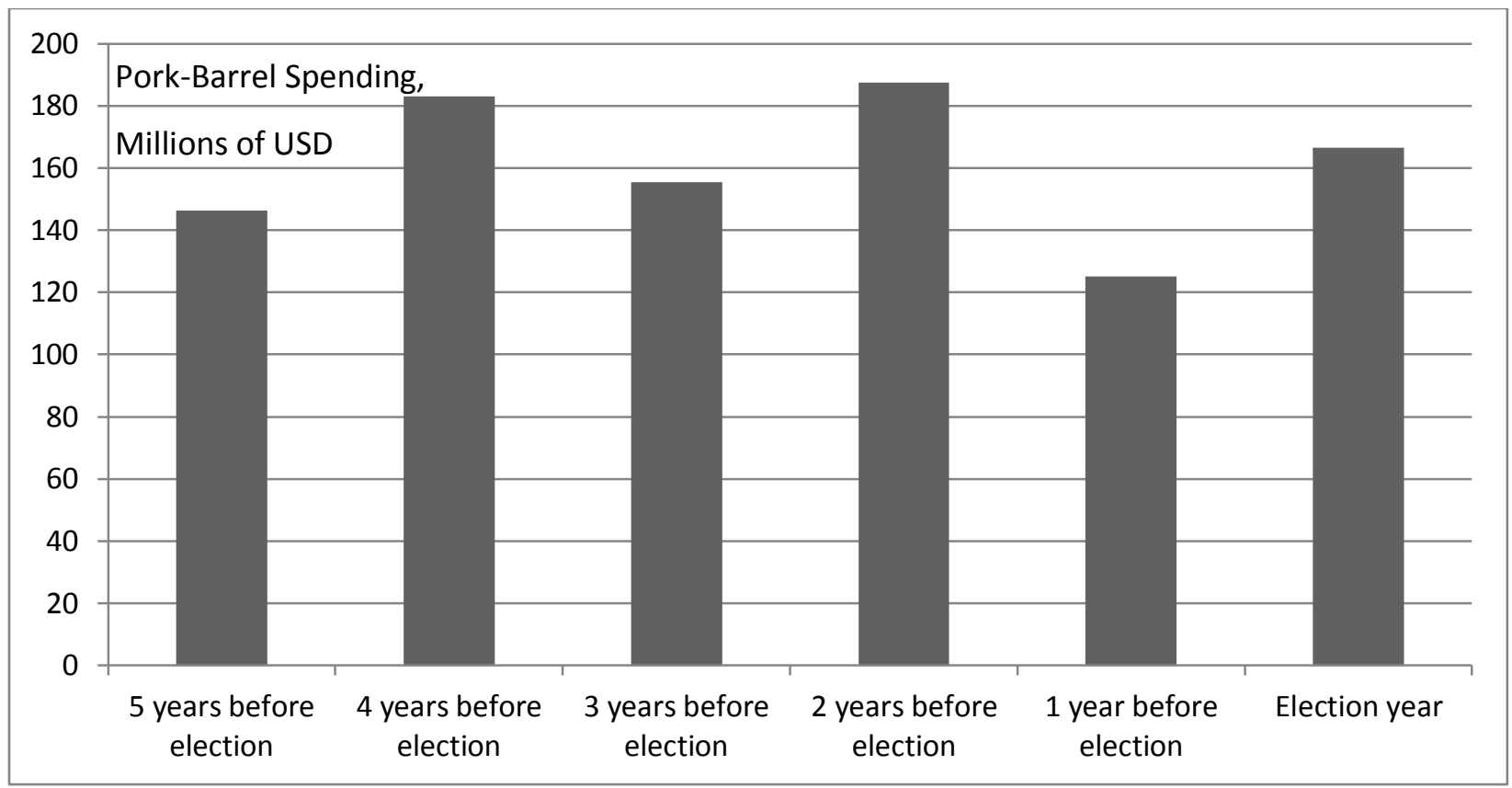

Figure 3: Average Pork-Barrel Spending by Years to Election

In order to assess differences between the impacts of pork-barrel spending and general appropriations on fundraising, a federal aid variable from the US Census is also included as an independent variable. This variable measures the amount of federal aid appropriated to each state. The federal aid is calculated by federal outlays to states from a variety of federal agencies $^{10}$. The data are collected from the United States Census Statistical Abstracts of the United States, specifically from the section titled "Federal Aid to State and Local Governments-Selected Programs by State." The Federal Aid variable does not include Social Security or Medicare. In addition, I removed Medicaid spending. Two forms of this variable are used. The first is the aggregate federal appropriations in billions of dollars during the Senator's six-year term. The second is the annual, disaggregated federal appropriation in the years prior

\footnotetext{
${ }^{10}$ These agencies include the Department of Agriculture, Department of Commerce, Department of Defense, Department of Education, Department of Energy, Environmental Protection Agency, Department of Homeland Security, Department of Housing and Urban Development, Department of the Interior, Department of Justice, Department of Labor, Department of Transportation and Department of the Treasury
} 
to an incumbent's re-election year. Unfortunately, due to budget cuts, the US Census no longer collects these data. As a result the regressions that use federal appropriation data are restricted to $2004-2010$.

By using the appropriations variable in addition to the pork-barrel spending variables, I am able to determine whether or not general appropriation spending has the same impact on fundraising as pork-barrel spending. If pork-barrel spending is shown to be more effective, then the estimates provide an explanation for the attraction that pork-barrel spending seems to have for Senators and other politicians.

Characteristics of individual senators were also collected. The number of terms variable measures the seniority of the Senator in the Senate. As the number of terms increases, a Senator normally gains additional power and influence, and should therefore be able to increase the amount of federal money for their state. Because seniority rather than experience is of interest, experience in other offices such as in the House of Representatives or state legislature is not of interest. Insofar as experience may also affect a Senator's effectiveness, I include a binary variable indicating whether or not the Senator previously served in the House of Representatives. Finally, previous success may have an impact on fundraising. Large donors only benefit if their candidate wins. Therefore, a greater likelihood of winning may increase the incumbent's ability to fundraise. Thus, the percentage of the vote received in the previous general election is included to measure past success.

The competitiveness of the challenger is also considered. As the likelihood of the incumbent losing their bid for re-election increases, the need for fundraising also increases. To measure the effect of challengers on fundraising, the amount of money raised by the challenger is 
collected from the Federal Election Commission and the Center for Responsive Politics' 'Open Secrets.' As the challenger increases their fundraising, the race becomes more competitive increasing the need and level of incumbent fundraising.

The incumbent's ability to fundraise for the general election may also depend on both the primary election and the incumbent's cash-on-hand. First, a binary variable is used if the incumbent received less than $70 \%$ of the vote in the primary election ${ }^{11}$. This is important as an incumbent may have to spend a significant amount to simply make it to the general election. Therefore, I anticipate a negative relationship between total fundraising and the percentage of the vote received in the primary election because an incumbent who is relatively unchallenged in the primary will not need to fundraise as much during the total election cycle. In addition, the incumbent's cash-on-hand is also included. This variable can be important as it may reduce the incumbent's need to raise funds for the current election cycle.

The population of a state can also influence total fundraising. States with a larger population increase a legislator's ability to fundraise. The log of state population, gathered from the US census, is included.

There has also been some debate over whether or not females have greater difficulty in raising funds due to the historical male-dominated environment of the United States political system (Uhlaner and Schlozman 1986). Therefore a binary variable is included which has a value of one if the incumbent is female.

Finally, I only use incumbents who served a full term. Therefore, Senators who were appointed during the previous term or won a special election are not included as they do not

\footnotetext{
${ }^{11}$ I used multiple values from $60 \%$ to $90 \%$ and got very similar results.
} 
have the full six years to obtain funding. ${ }^{12}$ From 2004-2012, 117 incumbent met this criteria and were included. The descriptive statistics and the sources for the data set are shown in table 11.

Table 11: Descriptive Statistics for State-Level Regression

\begin{tabular}{|c|c|c|c|c|c|c|}
\hline Variable & Source & Obs. & Mean & St. Dev. & Min & Max \\
\hline Incumbent Fundraising (millions of \$) & FEC & 117 & 10.762 & 7.481 & 1.444 & 51.567 \\
\hline Challenger Fundraising (millions of \$) & FEC & 117 & 4.060 & 5.847 & 0.001 & 28.162 \\
\hline Fundraising Advantage (in \%) & FEC & 117 & 81.354 & 17.416 & 36.222 & 99.992 \\
\hline Total Pork-Barrel Funding (millions of \$) & CAGW & 117 & 963.983 & 700.992 & 99.669 & 3640.200 \\
\hline Pork-Barrel Funding during election year & CAGW & 117 & 166.427 & 151.641 & 0.000 & 733.634 \\
\hline Pork-Barrel Funding year prior & CAGW & 117 & 125.093 & 135.391 & 0.000 & 588.800 \\
\hline Pork-Barrel Funding two years prior & CAGW & 117 & 187.558 & 138.218 & 16.600 & 671.800 \\
\hline Total Federal Aid (billions of \$) & Census & 101 & 40.213 & 55.960 & 1.100 & 296.400 \\
\hline Federal Aid during election year & Census & 101 & 9.585 & 12.036 & 1.200 & 66.600 \\
\hline Federal Aid year prior & Census & 101 & 9.077 & 11.408 & 1.100 & 62.000 \\
\hline Federal Aid two years prior & Census & 101 & 8.433 & 10.506 & 1.100 & 53.800 \\
\hline Number of Terms in Current Office & Congress & 117 & 2.521 & 1.705 & 1.000 & 8.000 \\
\hline Log(Population) & Census & 117 & 0.571 & 0.461 & -0.292 & 1.580 \\
\hline Incumbent faced challenger in primary? & FEC & 117 & 0.436 & 0.498 & 0.000 & 1.000 \\
\hline Female* & Congress & 117 & 0.197 & 0.399 & 0.000 & 1.000 \\
\hline Cash-on-Hand (millions of dollars) & OpenSecrets & 117 & 1.726 & 2.918 & 0.000 & 17.800 \\
\hline Percentage of vote in previous general election & FEC & 117 & 60.876 & 9.316 & 47.880 & 99.000 \\
\hline House of Representatives* & Congress & 117 & 0.564 & 0.498 & 0.000 & 1.000 \\
\hline
\end{tabular}

\section{Estimation Strategy}

The models estimated below have the form:

$$
\text { Fundraising }=\beta_{0}+\beta_{i} \cdot \text { pork }+\beta_{j} \cdot \text { control }+\beta_{k} \cdot \text { election year }+\varepsilon
$$

where pork is the amount of state-specific spending, control is the array of control variables described above, election year is a binary election year variable and $\varepsilon$ is the error term.

\footnotetext{
${ }^{12}$ Several minor data anomalies appeared during the estimation. For example, some candidates do not face a viable challenger. In some races, the incumbent does legally have a challenger, but the incumbent raises most of the money and receives most of the vote. I consider this situation in the appendix.
} 
To determine whether and to what degree pork-barrel appropriations impact fundraising, two series of estimates are undertaken for each dependent variable. First, aggregated porkbarrel spending and the other control variables are used to estimate the total amount of funds raised by the incumbent. Next, the possibility of an electoral cycle in pork and pork-induced donations are estimated using annual data for the three years leading up to the Senator's reelection bid. The inclusion of annual values also explores whether timing is important when considering the effects of pork-barrel spending on future fundraising.

\subsection{Estimation and Analysis}

The first dependent variable estimated is the total amount of money raised by the incumbent in millions of dollars during the election cycle as in Krebs (2001) and Bonneau (2007). The second dependent variable is the share of fundraising as the percentage of the overall fundraising the incumbent accounted for in their specific race. For example, if the incumbent raised $\$ 7$ million and the challenger raised $\$ 3$ million, then the incumbent would have a $70 \%$ share of the fundraising as they raised $\$ 7$ million of the $\$ 10$ million total raised in that specific electoral battle. Both Samuels (2002) and Stratmann (2013) use the share of fundraising variable. The share of fundraising has several advantages over the total fundraising variable. First, population does not matter when the share of fundraising is used as it is simply a percentage of total fundraising. In addition, price level differences do not matter. Because the spending in Senate campaigns can vary drastically, the fundraising advantage variable allows for a more straightforward comparison of Senate races. The fundraising data are collected from the Federal Election Commission and the Center for Responsive Politics' 'Open Secrets.' 
The first regression uses a pooled ordinary least squares regression (OLS) approach to estimate total fundraising. The second estimate utilizes the yearly pork-barrel appropriations during the election year and two years prior in lieu of the total, six-year pork-barrel appropriations. Regressions 3 and 4 replicate the first two regressions using the share of fundraising variable in place of the total fundraising variable.

Next, the same four regressions are repeated using federal aid to states instead of porkbarrel appropriations. Regression 5 uses the six-year federal outlays while regression 6 replaces the aggregate appropriation with annual outlays during the election year and two year prior in order to explore the possibility of an electoral cycle in the effects of state appropriations on overall fund raising. Finally, regressions 7 and 8 replicate regressions 5 and 6 using the share of fundraising variable in place of the total fundraising variable.

Unlike Samuels (2002) and Stratmann (2013), the present study includes federal elections from 2004 to 2012 instead of a single election. Therefore, panel estimation techniques can be used. Each of the eight regressions above are repeated using panel modeling techniques.

\section{Results: OLS Estimates of Fundraising with Pork-Barrel Spending}

Table 12 displays the results of the pooled OLS estimates of both total fundraising (regressions 1-2) and share of fundraising (regressions 3-4) including both the aggregate porkbarrel appropriations and the yearly pork-barrel appropriations. For regressions 1 and 2, the challenger fundraising variable is both significant and positively correlated with pork-barrel spending in their states. In addition, cash-on-hand and the log of the population are all significant and correlated with incumbent fundraising. 
There are also two surprises in the results. First, the female variable is both positive and significant which indicates that females may actually have a greater fundraising advantage. This is likely due to women's historical barriers to entry into the political arena. Females must accumulate more fundraising than the average male candidate in order to increase competitiveness in the election. The second surprise is that success in previous elections is negatively correlated with total fundraising. This could be a result of popular incumbents not needing to fundraise.

When pork-barrel spending is disaggregated based on years until re-election, \$1 million worth of pork-barrel spending in both the election year and the year prior lead to a $\$ 17,000$ increase in fundraising. However, these estimates are not always sufficiently precise to distinguish the coefficients from zero at the conventional levels of significance. In regression 1 , total pork-barrel appropriations are not significantly related to total fundraising.

Evidence of a pork-barrel electoral cycle effect is also evident. The amount of pork-barrel spending two years before the Senator's re-election bid and the amount of fundraising by said Senator are negatively related. This result makes it seem as though additional pork-barrel spending two years prior to the Senator's election can actually reduce their fundraising potential. While this may seem counterintuitive at first, it is important to remember that Senators are elected during different years, so it is highly likely that a donor will attempt to contribute to candidates standing for election in the year of interest. This is especially likely when the two Senators belong to the same political party giving them an even greater incentive to work together. So, even though the results make it seem as though the pork-barrel spending during that time period are hurting the Senator's fundraising, it is more likely that campaign 
contributions created by that pork-barrel spending are actually going to the other Senator in the state. This fact is likely why the total pork-barrel spending from regression 1 is insignificant as fundraising is going to shift among candidates based on the years to re-election. The three other years of the term are not included because they did not yield any significant results.

Regressions 3 and 4 use the share of fundraising as the dependent variable. The log of the population is not included because while the number of people in a state is likely to affect the level of total fundraising, it does not impact the percentage of funds accounted for by the incumbent. In addition, challenger fundraising is not included since it is already part of the share of fundraising variable. As was the case with the first two regressions, the cash-on-hand variable is significant. Unlike the first set of regressions, the previous general election performance is positively correlated with share of fundraising.

However, as was the case with regression 1, the total pork-spending variable from regression 3 is insignificant and seemingly unrelated to fundraising. Similar to regressions 1 and 2, the pork-barrel spending appropriated during the election year is both significant and positively correlated with share of fundraising. Specifically, a \$1 million increase in pork-barrel spending leads to a $0.04 \%$ increase in the incumbent's share of fundraising.

The first series of estimates shed light on the first two hypotheses of this paper. First, porkbarrel appropriations evidently have a positive impact on fundraising, other things being equal. Second, the timing of pork-barrel spending matters. Partly because of electoral cycles, porkbarrel spending only seems to have an impact on fundraising in the election year. This suggests that politicians have an incentive to properly time their appropriations, that is to say, to create an electoral pork-barrel spending cycle. Donors evidently suffer from the 'what have you done 
for me lately' attitude, and consequently the incumbent should minimize the time between the benefit to the potential donor and the time when donations are most needed.

Table 12: Pooled OLS Regressions using Pork-Barrel Spending (Regressions 1-4)

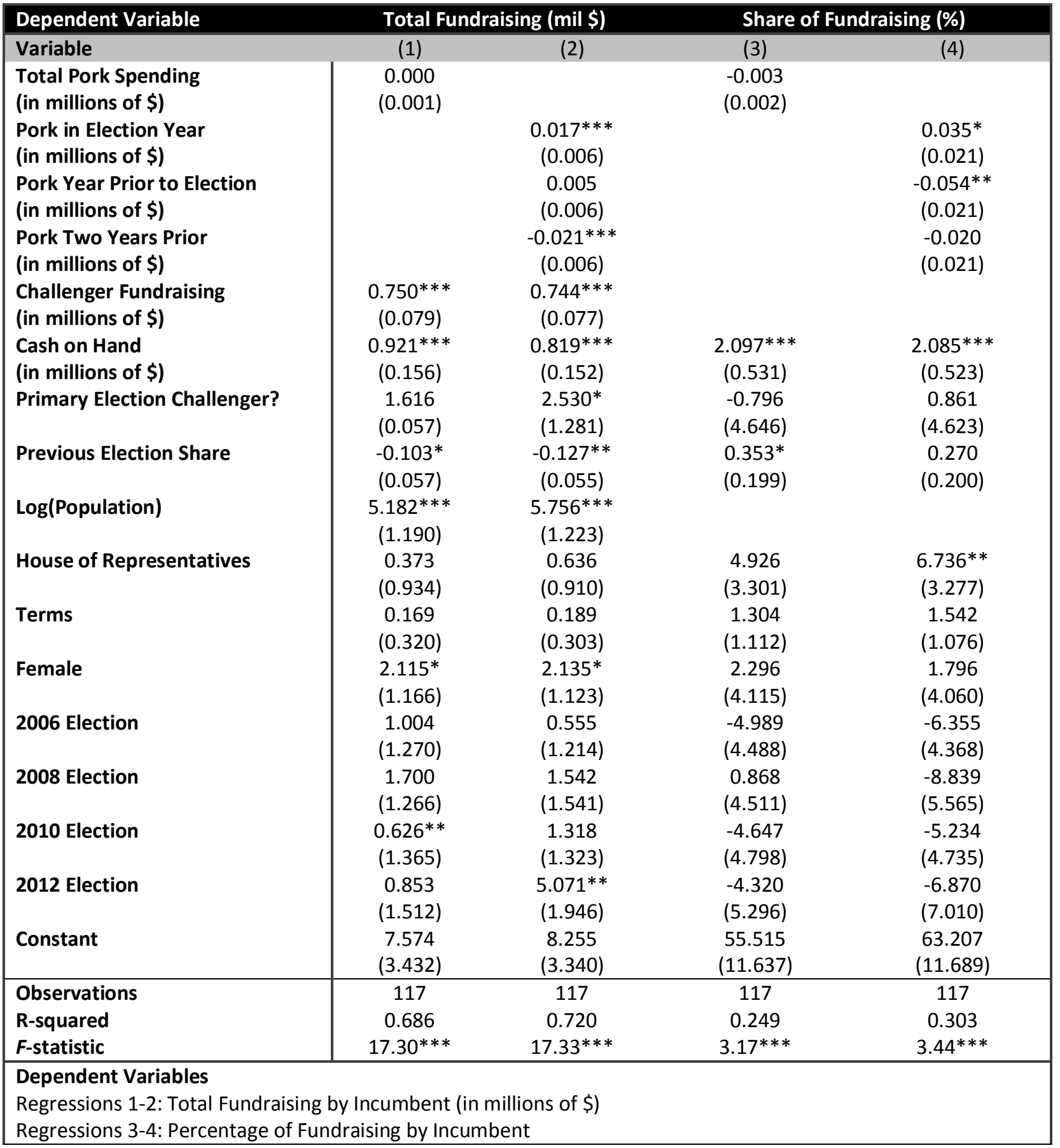

Standard errors in parentheses: $* * *=1 \%, * *=5 \%, *=10 \%$ significance level 


\section{OLS Estimates of Fundraising with Federal Appropriations}

The next four regressions replicate the first four, this time using federal aid to states as opposed to the more specific pork-barrel spending. As discussed, due to a reduction in federal funding, the US Census stopped collecting the federal outlay data after 2010.

Table 13: Pooled OLS Regressions using Federal Aid to States (Regressions 5-8)

\begin{tabular}{|c|c|c|c|c|}
\hline \multirow{2}{*}{$\begin{array}{l}\text { Dependent Variable } \\
\text { Variable }\end{array}$} & \multicolumn{2}{|c|}{ Total Fundraising (mil \$) } & \multicolumn{2}{|c|}{ Fundraising Advantage (\%) } \\
\hline & (5) & (6) & (7) & (8) \\
\hline $\begin{array}{l}\text { Total Federal Aid } \\
\text { (in millions of } \mathbf{\text { ) }}\end{array}$ & $\begin{array}{l}-0.001 \\
(0.019)\end{array}$ & & $\begin{array}{l}-0.014 \\
(0.031)\end{array}$ & \\
\hline Federal Aid in Election Year & & $-1.002 * *$ & & 0.686 \\
\hline (in millions of \$) & & $(0.449)$ & & $(1.725)$ \\
\hline Federal Aid Year Prior to Election & & 0.784 & & -3.181 \\
\hline (in millions of \$) & & $(0.686)$ & & $(2.600)$ \\
\hline Federal Aid Two Years Prior & & 0.544 & & 2.589 \\
\hline (in millions of \$) & & $(0.462)$ & & (1.714) \\
\hline Challenger Fundraising & $0.803 * * *$ & $0.782 * * *$ & & \\
\hline (in millions of \$) & $(0.085)$ & (0.079) & & \\
\hline Cash on Hand & $0.893 * * *$ & $0.631^{* * *}$ & $1.698 * * *$ & $1.784 * * *$ \\
\hline (in millions of \$) & $(0.156)$ & $(0.157)$ & $(0.535)$ & $(0.583)$ \\
\hline Primary Election Challenger? & 1.807 & 1.731 & -6.092 & -5.557 \\
\hline & (1.416) & (1.502) & (4.999) & (5.027) \\
\hline Previous Election Share & $\begin{array}{l}-0.079 \\
(0.058)\end{array}$ & $\begin{array}{l}-0.070 \\
(0.054)\end{array}$ & $\begin{array}{l}0.393^{*} \\
(0.200)\end{array}$ & $\begin{array}{l}0.382^{*} \\
(0.202)\end{array}$ \\
\hline Log(Population) & $\begin{array}{c}5.770 * * * \\
(1.448)\end{array}$ & $\begin{array}{l}1.788 \\
(1.501)\end{array}$ & & \\
\hline House of Representatives & $\begin{array}{c}0.283 \\
(0.990)\end{array}$ & $\begin{array}{l}0.340 \\
(0.919)\end{array}$ & $\begin{array}{l}4.709 \\
(3.491)\end{array}$ & $\begin{array}{l}5.448 \\
(3.525)\end{array}$ \\
\hline Terms & $\begin{array}{c}0.112 \\
(0.315)\end{array}$ & $\begin{array}{l}0.042 \\
(0.289)\end{array}$ & $\begin{array}{c}0.296 \\
(1.107)\end{array}$ & $\begin{array}{c}0.335 \\
(1.110)\end{array}$ \\
\hline Female & $\begin{array}{c}1.881 \\
(1.265)\end{array}$ & $\begin{array}{l}-0.094 \\
(1.226)\end{array}$ & $\begin{array}{l}-2.560 \\
(4.481)\end{array}$ & $\begin{array}{l}-1.996 \\
(4.709)\end{array}$ \\
\hline 2006 Election & $\begin{array}{c}0.771 \\
(1.257)\end{array}$ & $\begin{array}{l}-0.077 \\
(1.213)\end{array}$ & $\begin{array}{l}-5.134 \\
(4.404)\end{array}$ & $\begin{array}{l}-6.813 \\
(4.595)\end{array}$ \\
\hline 2008 Election & $\begin{array}{l}1.618 \\
(1.146)\end{array}$ & $\begin{array}{c}1.301 \\
(1.156)\end{array}$ & $\begin{array}{l}0.966 \\
(4.461)\end{array}$ & $\begin{array}{c}1.320 \\
(4.456)\end{array}$ \\
\hline 2010 Election & $\begin{array}{c}0.498 \\
(1.355)\end{array}$ & $\begin{array}{l}1.274 \\
(1.347)\end{array}$ & $\begin{array}{l}-3.196 \\
(4.745)\end{array}$ & $\begin{array}{l}-1.375 \\
(5.157)\end{array}$ \\
\hline Constant & $\begin{array}{l}5.704 \\
(3.534) \\
\end{array}$ & $\begin{array}{c}6.459 \\
(3.285) \\
\end{array}$ & $\begin{array}{r}54.861 \\
(11.677) \\
\end{array}$ & $\begin{array}{r}54.524 \\
(11.722) \\
\end{array}$ \\
\hline Observations & 101 & 101 & 101 & 101 \\
\hline R-squared & 0.714 & 0.765 & 0.253 & 0.272 \\
\hline F-statistic & $18.27^{* * *}$ & $19.96 * * *$ & $3.05^{* * *}$ & $2.75^{* * *}$ \\
\hline
\end{tabular}

Standard errors in parentheses: $* * *=1 \%, * *=5 \%, *=10 \%$ significance level 
Therefore, these regressions cover the Senatorial general elections from 2004-2010. The results are displayed in table 13 . For each of the regressions, the control variables behave in much the same way as they did in regressions $1-4$, so I will not repeat the results. The main difference between pork-barrel spending and federal aid is that there is no significant relationship between federal aid and fundraising other than the federal aid appropriated during the election year which is actually negatively correlated with total fundraising. These results support the hypothesis that general federal appropriations do not have the same impact on fundraising. Even when federal spending such as Social Security, Medicare and Medicaid are excluded, there is still no discernable linkage between federal aid spending and fundraising.

\section{Panel Estimates of Fundraising with Pork-Barrel Spending}

Even though the pooled OLS results support the three hypotheses regarding the impact pork-barrel spending and appropriation spending have on fundraising, a panel approach is used as a robustness check. I repeat the previous eight regressions using panel estimates. The Hausman Test indicates that a fixed effect model should be used when the dependent variable is total fundraising while a random effect model should be used when the dependent variable is the incumbent's share of fundraising. This result is not surprising as the total fundraising variable, due to being measured in millions of dollars, is easily impacted by state-specific conditions such as population, price-level and being a "swing-state."

Table 14: Hausman Test Results

\begin{tabular}{|c|c|}
\hline Regression & Chi-Squared Statistic \\
\hline Total Fundraising - Total Pork Spending & $124.23^{* *}$ \\
Total Fundraising - Yearly Pork Spending & $31.13^{*}$ \\
Fundraising Percent - Total Pork Spending & 5.83 \\
Fundraising Percent - Yearly Pork Spending & 5.95 \\
\hline $\mathrm{H}_{0}:$ A random effects model should be used. \\
$* * *=1 \%, * *=5 \%, *=10 \%$ significance level \\
\hline
\end{tabular}


I continue to use the election year binary variables in order to control for the election year. The years after the 2008 financial crisis would, for example, be associated with increased targeted and general spending, but donors may have had less income to make donations from.

Table 15 gives the estimates for regressions 9-12. The results are similar to the estimates from regressions 1-4 with only minor differences. First of all, the control variables in all four cases continue to behave similarly to the pooled OLS regressions. Again, challenger fundraising, service in the House of Representatives, the number of terms served and being female are all significant and positively correlated with total fundraising. Second, the regressions utilizing the total incumbent fundraising variable continue to provide more robust results.

Again, pork-barrel spending influences fundraising but only when properly timed. Specifically, when \$1 million worth of pork-barrel money is brought into the state during the Senator's election year, the Senator is able to increase their fundraising by $\$ 24,000$; that is, an additional dollar of fundraising costs around $\$ 42$ worth of pork-barrel money. A key difference between the panel results and pooled OLS results is that total pork-barrel spending does seem to be significant and positively correlated with total fundraising. This indicates that pork-barrel spending throughout a Senator's entire term does have a net positive effect on their fundraising. Additionally, pork-barrel spending continues to influence the percent of fundraising by the incumbent, but only when properly timed. 
Table 15: Panel Regressions using Pork-Barrel Spending (Regressions 9-12)

\begin{tabular}{|c|c|c|c|c|}
\hline \multirow{2}{*}{$\begin{array}{l}\text { Dependent Variable } \\
\text { Variable }\end{array}$} & \multicolumn{2}{|c|}{ Total Fundraising (mil \$) } & \multicolumn{2}{|c|}{ Fundraising Advantage (\%) } \\
\hline & (9) & (10) & (11) & (12) \\
\hline Total Pork Spending & $0.005^{*}$ & & -0.003 & \\
\hline (in millions of \$) & $(0.003)$ & & $(0.002)$ & \\
\hline $\begin{array}{l}\text { Pork in Election Year } \\
\text { (in millions of \$) }\end{array}$ & & $\begin{array}{c}0.024^{* * *} \\
(0.006)\end{array}$ & & $\begin{array}{l}0.035^{*} \\
(0.021)\end{array}$ \\
\hline Pork Year Prior to Election & & -0.002 & & $-0.054 * *$ \\
\hline (in millions of \$) & & $(0.006)$ & & $(0.021)$ \\
\hline Pork Two Years Prior & & -0.003 & & -0.020 \\
\hline (in millions of \$) & & $(0.013)$ & & $(0.021)$ \\
\hline Challenger Fundraising & $0.719 * * *$ & $0.706 * * *$ & & \\
\hline (in millions of \$) & $(0.089)$ & $(0.083)$ & & \\
\hline Cash on Hand & $0.526^{*}$ & 0.395 & $2.098^{* * *}$ & $2.085 * * *$ \\
\hline (in millions of \$) & $(0.286)$ & $(0.261)$ & $(0.531)$ & $(0.522)$ \\
\hline Primary Election Challenger? & 2.237 & $2.839 * *$ & -0.796 & 0.860 \\
\hline & (1.480) & (1.379) & (4.646) & (4.623) \\
\hline Previous General Election Share & $-0.133^{*}$ & $-0.172 * *$ & $0.353^{*}$ & $0.270 * *$ \\
\hline & $(0.081)$ & $(0.075)$ & (0.199) & $(0.197$ \\
\hline House of Representatives & 1.003 & $2.046^{*}$ & 4.926 & 6.736 \\
\hline & (1.184) & (1.114) & (3.301) & $(3.277)$ \\
\hline Terms & $0.770^{*}$ & $0.893 * *$ & 1.304 & 1.542 \\
\hline & $(0.407)$ & $(0.375)$ & $(1.112)$ & $(1.076)$ \\
\hline Female & $5.834 * * *$ & $5.346 * * *$ & 2.296 & 1.796 \\
\hline & $(1.759)$ & $(1.604)$ & $(4.115)$ & $(4.060)$ \\
\hline 2006 Election & 0.290 & 0.829 & -4.989 & -6.355 \\
\hline & $(1.372)$ & (1.217) & $(4.488)$ & $(4.368)$ \\
\hline 2008 Election & $2.705^{*}$ & 2.143 & 0.868 & -8.839 \\
\hline & $(1.453)$ & $(1.626)$ & (4.511) & (5.565) \\
\hline 2010 Election & 1.114 & 1.576 & -4.647 & -5.234 \\
\hline & (1.390) & $(1.281)$ & $(4.798)$ & $(4.735)$ \\
\hline 2012 Election & $3.401^{*}$ & $5.860 * * *$ & -4.320 & -6.870 \\
\hline & $(1.862)$ & $(2.018)$ & (5.295) & (7.010) \\
\hline Constant & 4.880 & 7.944 & 55.515 & 63.207 \\
\hline & (5.189) & (4.671) & (11.637) & (11.689) \\
\hline Observations & 117 & 117 & 117 & 117 \\
\hline Groups & 49 & 49 & 49 & 49 \\
\hline R-squared & 0.637 & 0.706 & 0.129 & 0.190 \\
\hline F/Wald-statistic & $8.07^{* * *}$ & $9.27^{* * *}$ & $34.83 * * *$ & $44.71 * * *$ \\
\hline
\end{tabular}

Standard errors in parentheses: $* * *=1 \%, * *=5 \%, *=10 \%$ significance level

\section{Panel Estimates of Fundraising with Federal Aid}

I continue the analysis by repeating the four fundraising regressions which utilize the federal aid variables instead of the pork-barrel spending variables. Again, the Hausman Test indicates that a fixed effects model should be used when the dependent variable is total 
fundraising and a random effects model should be used when the dependent variable is the share of incumbent fundraising. The result of each of the Hausman tests is given below.

Table 16: Hausman Test Results II

\begin{tabular}{|c|c|}
\hline Regression & Chi-Squared Statistic \\
\hline Total Fundraising - Total Pork Spending & $30.12^{* * *}$ \\
Total Fundraising - Yearly Pork Spending & $19.37^{*}$ \\
Fundraising Percent - Total Pork Spending & 4.29 \\
Fundraising Percent - Yearly Pork Spending & 3.48 \\
\hline $\mathrm{H}_{0}:$ A random effects model should be used. \\
$* * *=\mathbf{1 \% , * *}=\mathbf{5 \% , *}=\mathbf{1 0 \%}$ significance level \\
\hline
\end{tabular}

Table 17 gives the estimates for regressions 13-16. Again, the results are similar to the estimates from regressions 5-8. Each of the control variables behaves in exactly the same way as they did in regressions 5-8. One difference is that using the panel approach appears to show that federal aid spending is correlated with total fundraising although the total effect is ambiguous.

\section{Implications of Estimates}

Overall, the above results support the three hypotheses stated at the beginning of the paper. First, pork-barrel spending can have a positive and significant impact on fundraising. Second, the timing of the pork-barrel spending matters. To be specific, only pork-barrel spending in the election year seems to have an impact on campaign contributions. Third, the relationship between federal aid to states and incumbent fundraising is ambiguous; but, it is clear that amount of fundraising per dollar of pork-barrel spending is far greater than the amount of fundraising per dollar of federal aid. 
Table 17: Panel Regressions using Federal Aid (Regressions 13-16)

\begin{tabular}{|c|c|c|c|c|}
\hline Dependent Variable & Total Fu & ng (mil \$) & Fundrai & tage (\%) \\
\hline Variable & (13) & (14) & (15) & $(16)$ \\
\hline $\begin{array}{l}\text { Total Federal Aid } \\
\text { (in billions of \$) }\end{array}$ & $\begin{array}{l}-0.015 \\
(0.026)\end{array}$ & & $\begin{array}{l}-0.014 \\
(0.031)\end{array}$ & \\
\hline $\begin{array}{l}\text { Federal Aid in Election Year } \\
\text { (in billions of \$) }\end{array}$ & & $\begin{array}{c}-1.430 * * * \\
(0.459)\end{array}$ & & $\begin{array}{c}0.686 \\
(1.725)\end{array}$ \\
\hline $\begin{array}{l}\text { Federal Aid Year Prior to Election } \\
\text { (in billions of \$) }\end{array}$ & & $\begin{array}{c}0.845 \\
(0.757)\end{array}$ & & $\begin{array}{l}-3.181 \\
(2.600)\end{array}$ \\
\hline $\begin{array}{l}\text { Federal Aid Two Years Prior } \\
\text { (in billions of \$) }\end{array}$ & & $\begin{array}{c}1.642^{* * *} \\
(0.557)\end{array}$ & & $\begin{array}{c}2.589 \\
(1.713)\end{array}$ \\
\hline $\begin{array}{l}\text { Challenger Fundraising } \\
\text { (in millions of } \$ \text { ) }\end{array}$ & $\begin{array}{c}0.752^{* * *} \\
(0.106)\end{array}$ & $\begin{array}{c}0.705^{* * *} \\
(0.089)\end{array}$ & & \\
\hline Cash on Hand & 0.466 & 0.233 & $1.698 * * *$ & $1.784 * * *$ \\
\hline (in millions of \$) & (0.314) & $(0.264)$ & $(0.535)$ & $(0.583)$ \\
\hline Primary Election Challenger? & $\begin{array}{c}2.553 \\
(1.865)\end{array}$ & $\begin{array}{l}2.692^{*} \\
(1.515)\end{array}$ & $\begin{array}{l}-6.092 \\
(4.999)\end{array}$ & $\begin{array}{l}-5.556 \\
(5.027)\end{array}$ \\
\hline Previous General Election Share & $\begin{array}{l}-0.082 \\
(0.093)\end{array}$ & $\begin{array}{l}-0.030 \\
(0.076)\end{array}$ & $\begin{array}{l}0.393^{* *} \\
(0.200)\end{array}$ & $\begin{array}{l}0.382^{*} \\
(0.202)\end{array}$ \\
\hline House of Representatives & $\begin{array}{c}0.244 \\
(1.341)\end{array}$ & $\begin{array}{c}0.264 \\
(1.131)\end{array}$ & $\begin{array}{c}4.709 \\
(3.491)\end{array}$ & $\begin{array}{l}5.448 \\
(3.523)\end{array}$ \\
\hline Terms & $\begin{array}{l}0.486 \\
(0.476)\end{array}$ & $\begin{array}{l}0.474 \\
(0.393)\end{array}$ & $\begin{array}{c}0.296 \\
(1.107)\end{array}$ & $\begin{array}{c}0.335 \\
(1.110)\end{array}$ \\
\hline Female & $\begin{array}{l}4.616^{*} \\
(2.251)\end{array}$ & $\begin{array}{r}4.301^{* *} \\
(1.888)\end{array}$ & $\begin{array}{l}-2.560 \\
(4.481)\end{array}$ & $\begin{array}{l}-1.996 \\
(4.709)\end{array}$ \\
\hline 2006 Election & $\begin{array}{c}0.584 \\
(1.412)\end{array}$ & $\begin{array}{l}-1.231 \\
(1.245)\end{array}$ & $\begin{array}{l}-5.134 \\
(4.403)\end{array}$ & $\begin{array}{l}-6.813 \\
(4.595)\end{array}$ \\
\hline 2008 Election & $\begin{array}{l}2.745^{*} \\
(1.572)\end{array}$ & $\begin{array}{c}1.407 \\
(1.353)\end{array}$ & $\begin{array}{l}0.966 \\
(4.461)\end{array}$ & $\begin{array}{l}1.320 \\
(4.456)\end{array}$ \\
\hline 2010 Election & $\begin{array}{c}0.949 \\
(1.420)\end{array}$ & $\begin{array}{l}1.013 \\
(1.460)\end{array}$ & $\begin{array}{l}-3.196 \\
(4.745)\end{array}$ & $\begin{array}{l}-1.375 \\
(5.157)\end{array}$ \\
\hline Constant & $\begin{array}{c}8.696 \\
(5.454)\end{array}$ & $\begin{array}{l}-1.421 \\
(5.091)\end{array}$ & $\begin{array}{c}54.860 \\
(11.677) \\
\end{array}$ & $\begin{array}{c}54.524 \\
(11.722) \\
\end{array}$ \\
\hline Observations & 101 & 101 & 101 & 101 \\
\hline Groups & 49 & 49 & 49 & 49 \\
\hline $\begin{array}{l}\text { R-squared } \\
\text { F/Wald-statistic }\end{array}$ & $\begin{array}{c}0.650 \\
6.92 * * *\end{array}$ & $\begin{array}{c}0.776 \\
1020 * * *\end{array}$ & 0.114 & 0.144 \\
\hline $\begin{array}{l}\text { Dependent Variables } \\
\text { Regressions 13-14: Total Fundraisi } \\
\text { Regressions 15-16: Percentage of }\end{array}$ & $\begin{array}{l}\text { Incumbe } \\
\text { aising by }\end{array}$ & $\begin{array}{l}\text { llions of } \$ \\
\text { nt - Ranc }\end{array}$ & fects & \\
\hline
\end{tabular}

Standard errors in parentheses: $* * *=1 \%, * *=5 \%, *=10 \%$ significance level

These results suggest that legislators should prefer pork-barrel spending over general appropriations for their states, possibly because the former are more visible and easier to take credit for. It would be difficult for a single Senator to claim credit for a change in the entire 
Women, Infant and Children (WIC) system. However, a Senator could claim credit for a new highway, park, museum, or federal building in their state. This also lends support to universalism hypothesis of Weingast (1994), which states that politicians are likely to work together on targeted spending bills, because it is in their respective fundraising interests to do so.

\section{Caveats and Estimation Issues}

There are several variables which were not included in this study. The first is a party-based binary variable to determine if the legislator's political party impacts fundraising. Theoretically, this is not appropriate as there is very little evidence that a Senator's party impacts fundraising. Even though there is anecdotal evidence that Republicans have a greater ability to fundraise, there is little empirical evidence to support this claim. For example, Barack Obama raised $\$ 80$ million more than Mitt Romney in the 2012 presidential election even when PAC contributions are included.

Secondly, some studies use per capita measures. This is problematic for several reasons. First, it does not allow for a simple interpretation of the estimates. Instead of being able to estimate the number of dollars needed to increase fundraising by $\$ 1$, all of the values are based on the size of the population. More importantly, estimates of per capita campaign spending are very weak and do not shine much direct light on the questions of interest here.

Another possible change that could be made is to compare similar spending types. For example, there is enough available data to compare the impact of pork-barrel spending included in a transportation omnibus bill compared to the impact of federal spending by the Department of Transportation. As previously mentioned, Senators have much less control over 
the amount of money spent by executive agencies of the government. Therefore, incumbents can use pork-barrel spending to steer money to projects which they believe will provide a greater personal benefit.

\subsection{Conclusion}

This paper provides evidence that pork-barrel spending has a positive impact on an incumbent's ability to fundraise.

By extending past research by Krebs (2001), Samuels (2002), Bonneau (2007) and Stratmann (2013), I was able to model and estimate an incumbent Senator's ability to fundraise for reelection. The main novelty of the above estimates was the use disaggregated pork-barrel appropriations. When using total fundraising, a ten million dollar increase in pork-barrel appropriations in the election year leads to somewhere between a $\$ 170,000$ to $\$ 240,000$ increase in fundraising. When the share of fundraising is used as the dependent variable, the relationship is similar. Specifically, a $\$ 10$ million increase in pork-barrel spending leads to a $0.35 \%$ increase in the incumbent's fundraising share. This result is in line with the total fundraising results.

In addition, the results are robust as similar estimates are obtained using pooled OLS estimates and panel estimates. The results also suggest that state federal appropriations may increase fundraising by Senators, although less so than targeted expenditures. This supports the hypothesis that legislators prefer to use pork-barrel spending, other things being equal, because the results are more visible, easier to take credit for and easier to direct to certain parties. 


\subsection{Appendix: The Case of Competitive Elections}

In this section, I consider the situation where only the race is relatively competitive. Specifically, I only include a race if the incumbent receives less than $70 \%$ of the vote in the general election. Even though this threshold is relatively high, it cuts out nearly $20 \%$ of the available data. Reducing the threshold to $60 \%$ would eliminate 50 more races.

For the sake of time, I only include the four original pooled OLS regressions. The results are given below in table 18. The control variables behave just as they did in the original, untrimmed regressions. But, the main contribution from this change is the impact of the new data set on the pork-barrel spending variables. Specifically, the pork-barrel spending during the election year continues to be both significant and positively correlated with both fundraising dependent variables, but the coefficient is larger. In fact, incumbents facing a greater challenge in the general election can generate $10-20 \%$ more campaign contributions per million dollars of porkbarrel spending than unchallenged incumbents. This indicates that incumbents in closer races are able to increase their fundraising by a larger amount.

This result further establishes the main hypothesis of the paper that legislators can use pork-barrel spending to increase their fundraising. Consequently, politicians who face a tighter race feel an additional sense of urgency which is translated into a greater need to fundraise. In this situation, incumbents attempt to get the greatest return possible from their appropriations of pork-barrel money. 
Table 18: Competitive Pooled OLS Regressions using Pork-Barrel Spending (Regressions 1-4)

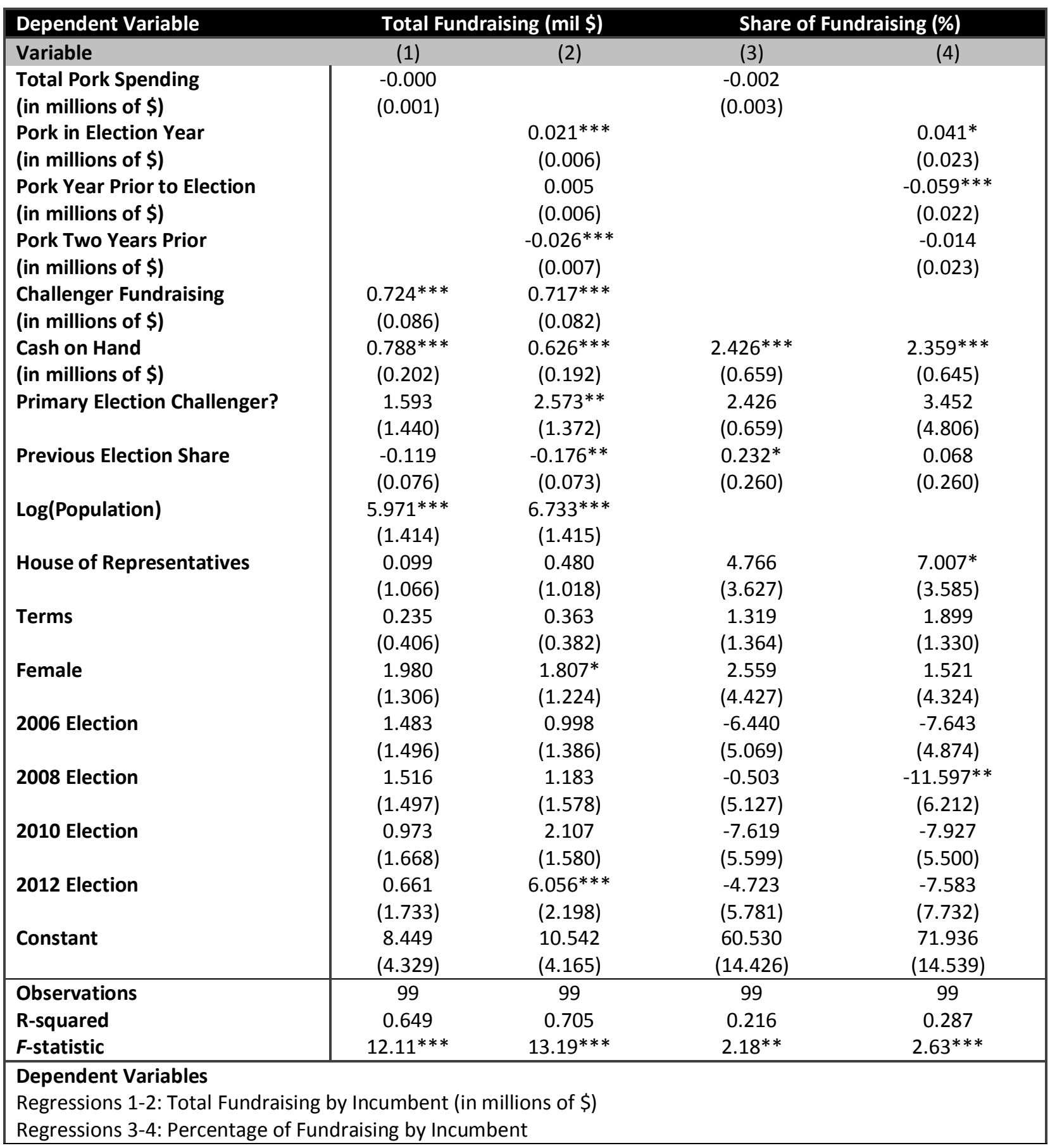

Standard errors in parentheses: $* * *=1 \%, * *=5 \%, *=10 \%$ significance level 


\title{
Chapter 4: The Impact of Pork-Barrel Spending on Electoral Success
}

\begin{abstract}
As discussed in the previous two chapters of this dissertation, pork-barrel spending can be used by incumbents for an electoral advantage. What has yet to be considered is the actual impact on an incumbent's re-election chances. This papers uses both a two-stage and three-stage least squares approach to identify the main determinants of an incumbent's share of the votes in the general election. Instead of looking for a direct link between pork-barrel spending and electoral success, I posit that there is actually an indirect linkage. Specifically, I hypothesize that pork-barrel spending has a positive impact on fundraising and said fundraising increases the likelihood of incumbent re-election. I find that for every $\$ 10$ million of pork-barrel spending, the incumbent's share of fundraising increases by $0.10 \%$ and for every $1 \%$ increase in share of fundraising, the incumbent increases their vote share by about $0.14 \%$. Therefore, a $\$ 1$ million increase in pork-barrel spending can lead to a $0.10 \%$ increase in vote share.
\end{abstract}

\subsection{Introduction}

It is generally believed that politicians are able to bolster their chances for re-election through the use of pork-barrel spending. Theoretical models produced by both economists and political scientists predict that politicians who are able to secure federal funding for their state or district will increase their chances of being re-elected (Inman and Fitts 1990; Bickers and Stein 1996; Levitt and Snyder 1997; Stratmann 2013). But, even with the theoretical foundations, there is surprisingly little empirical evidence that such an effect actually exists. Even so, many politicians appear to believe that securing federal funds will increase their likelihood of being re-elected based on their continued usage of pork-barrel spending.

For example, the Hurricane Sandy relief bill, in theory, should have been full of benefits for the citizens of the disaster-ravaged region. In turn, the voters in the area would reward their legislators for the disaster assistance by voting them back into office. Therefore, legislators inside of this geographical area would be able reap positive electoral benefits. Those electoral 
benefits could be extended to other regions by including additional targeted expenditures, and this was evidently done. The total Hurricane Sandy disaster relief bill had over $\$ 50$ billion in spending with much of it having nothing to do with the actual Hurricane Sandy disaster. This

illustrates legislators' strong attraction to pork-barrel spending. In addition, it supports the belief that logrolling is likely to occur even with disaster relief (Congleton 2006; Sobel, Coyne et al. 2007).

Pork-barrel projects may increase the likelihood of an incumbent being re-elected through three channels. First, they may increase the number of votes received if constituents see tangible improvements through pork-funded projects. For instance, constituents may reward their legislator for securing funds for a new museum or highway. Second, pork-barrel spending may improve the economic conditions of an area. If the legislator is able to create jobs or increase income levels through pork-barrel spending, such results should increase the chance of being re-elected. Third, legislators may funnel pork-barrel money into projects which benefit concentrated groups in their districts. Said groups may then choose to reward the incumbent by donating to their re-election campaign. The additional campaign contributions would be used to increase the likelihood of being re-elected. This paper examines the third channel.

\subsection{Pork-Barrel Spending, Fundraising and Electoral Success}

Attempting to determine what factors influence electoral success is not a new endeavor. In general, the amount of money a legislator spends during a campaign has consistently been shown to be directly related to their success in the election (Palda 1973; Welch 1974; Palda 1975; Dawson and Zinser 1976; Welch 1976; Stratmann 2013). One important distinction that must be made when studying elections is the difference between an incumbent, the politician 
currently holding the office, and the challenger, the politician attempting to win the incumbent's office. While some early studies have incorrectly grouped incumbents and the challengers together into a single analysis (Glantz, Abramowitz et al. 1976; Jacobson 1976), later studies have recognized that incumbents have a distinct advantage over challengers in their reelection campaigns ${ }^{13}$.

Some of the incumbency advantage is derived from the link between the likelihood of a candidate being elected and the probability of someone donating to their campaign. Because incumbents have already shown potential contributors they can win an election, the incumbent is more likely to receive campaign contributions (Welch 1974; Ban-Zion and Eytan 1975; Dawson and Zinser 1976; Welch 1977; Pastine and Pastine 2012). Thus, there is a self-fulfilling prophecy when it comes to campaign financing. Candidates can only be successful if they are able to fundraise; but, successful candidates have an easier time fundraising. This has become an even bigger issue due to the high-cost of advertising coupled with the effectiveness of campaign advertisements aired on television (Stratmann 2006).

Another reason incumbents have an advantage is due to their ability to indirectly use tax revenues to campaign for re-election. Incumbents can use their office to create programs which provide benefits to potential voters in their district (Cover 1976; Perdue 1977; Jacobson 1978; Grossman and Helpman 1994; Erikson and Palfrey 2000). This essentially permits incumbents to use taxpayer money, often in the form of targeted expenditures, to increase their support

\footnotetext{
${ }^{13}$ For example, Erikson 1971, Erikson 1972, Mayhew 1974, Ferejohn 1977, Fiorina 1977, Born 1979, Alford and Brady 1981, Collie 1981, Krehbiel and Wright 1983, Garand and Gross 1984, Cain, Ferejohn et al. 1987, Jacobson 1987, Ansolabehere, Brady et al. 1988, Alford and Niemi 1989, Gelman and King 1990, Jacobson 1990, King and Gelman 1991, Cox and Katz 1996, Levitt and Wolfram 1997, Ansolabehere, Synder et al. 2000, Hodler, Loertscher et al. 2010.
} 
among voters and campaign donors. Unless challengers already have some existing legislative position, they must rely solely on promises to generate such support.

Of course, simply bringing federal money into a state may not be enough. A significant number of voters or donors have to assign credit for it to incumbents. Many federal programs award funding to states through the use of grant processes which are not directly controlled by the legislator. Because the legislator cannot easily take direct credit for general spending, it is not likely to be as beneficial for re-election as more visible, targeted expenditures. Pork-barrel spending provides clearer evidence of an incumbent influence in Congress. Without project visibility, earmark spending is not likely to be an effective method of increasing re-election chances (Stein and Bickers 1994).

Even with plenty of anecdotal evidence highlighting the popularity of pork-barrel spending in Congress, there remains a good deal of controversy over the magnitude of the effect of targeted expenditures on re-election prospects (Evans 2004)." Several papers have concluded that pork-barrel spending does not have an impact on an incumbent's chances of being reelected (Feldman and Jondrow 1984; Stein and Bickers 1995; Frisch 1998).

On the other hand, there is also research that suggests that federal spending in one's district or state has a positive impact on electability (Weingast 1979; Shepsle and Weingast 1981; Weingast, Shepsle et al. 1981; Niou and Ordeshook 1985; Ferejohn and Krehbiel 1987; Inman 1988; Inman and Fitts 1990; Bickers and Stein 1996; Shepsle, Dickson et al. 2002; Keefer and Khemani 2009). For example, Levitt and Snyder (1997) find that for each additional \$100 per capita that a legislator is able to secure for his or her district, the likelihood of re-election 
increases by approximately $2 \%$. The important caveat is that constituents must be aware that federal money is being funneled into the district.

In a recent study, Stratmann (2013) points out that one of the major drawbacks of previous research is that it does not distinguish between federally-awarded money and earmarks. A district can receive a large amount of federal assistance but this may have little to do with the legislator's ability to secure federal funding, because so many federal grants are distributed through formulas that are not directly impacted by individual state or district legislators. Stratmann finds evidence that the average incumbent increases his or her share of the vote by around $1 \%$ by increasing federal earmark spending by $\$ 50$ million. This amounts to a $\$ 15$ per capita increase in a district with a population of 650,000 residents (Stratmann 2013). However, Stratmann's research does not fully explain the motivation of the legislator. The goal of this paper is to determine why politicians are attracted to pork-barrel spending.

A complete model of electoral success has to simultaneously account for pork-barrel spending, fundraising, and electability. The difficulty in modeling the relationship between the three variables is the endogoneity.

Consider the relationship between fundraising and electoral success. A candidate can increase his or her likelihood of reelection by securing additional fundraising money, but a candidate who is likely to win an election is also more likely to raise additional funds. As a consequence, there is a bidirectional relationship between fundraising and electability. This causes the results from an ordinary least squares analysis to be biased. In addition, a candidate who is almost guaranteed to win may not actually need fundraising assistance. Robert C. Byrd, the late senator from West Virginia, never received less than $64 \%$ of the popular vote in any bid 
for re-election; therefore, he was able to rely on his name and reputation rather than fundraising to win elections - which was partly associated with his amazing ability to secure targeted grants for his state.

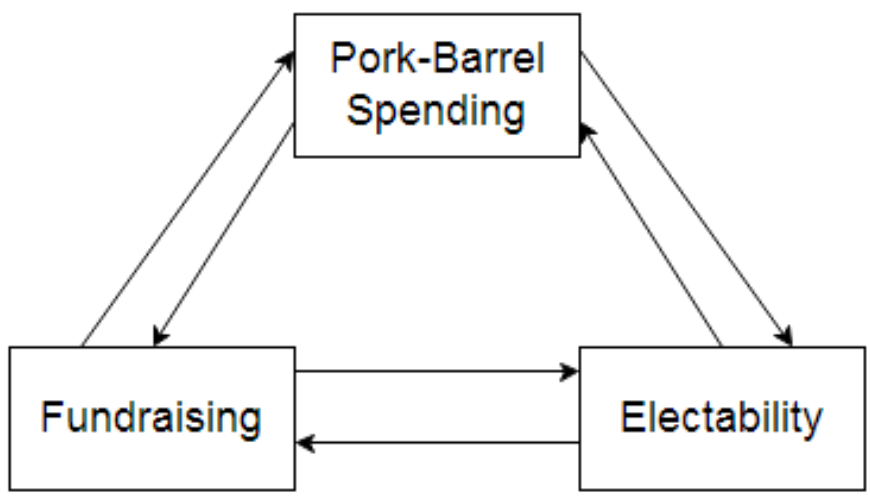

Figure 4: The Connection Between Pork-Barrel Spending, Fundraising and Electability

Each of the above links have been studied independently of one. There are many papers on the link between fundraising and electability (for example, Bonneau (2007) and Abrams and Settle (2004)).There are also papers on the link between electability and fundraising (for example, Dawson and Zinser (1976) and Welch (1977).) A few researchers have also attempted to determine the impact of pork-barrel spending on electability (for example, Levitt and Snyder (1997) and Stratmann (2013)). The previous chapter of this dissertation studies the link between pork-barrel spending and fundraising. Samuels (2002) contends that pork-barrel spending does create electoral gains but indirectly. Samuels finds that legislators in Brazil increase their likelihood of re-election by engaging in pork-barrel projects, but the increased likelihood is due to the increased fundraising which is a result of the pork-barrel projects (Samuels 2002). 
Overall, these papers suggest that simultaneous equation bias is likely to be a problem for much of the literature. This paper attempts to overcome that problem estimating pork-barrel spending, fundraising and electoral success together in a single empirical analysis. The results suggest that pork-barrel spending does not impact electability; instead, pork-barrel spending increases an incumbent's ability to fundraise and said fundraising is responsible for the increase in electability.

\subsection{Data and Modeling}

I use a model based on Samuels (2002) and an estimation strategy that is similar to Stratmann (2013). Following Samuels, three hypotheses are tested: first that pork-barrel spending does not directly help incumbents win elections, second that pork-barrel spending increases an incumbent's access to campaign fundraising and third that money helps incumbents win reelection. If each of the three hypotheses is shown to be true, then I will have sufficient evidence to prove the main thesis of this paper: pork-barrel spending does not directly impact an incumbent's chances of winning an election; instead, pork-barrel spending has a positive impact on fundraising which subsequently increases the likelihood of re-election. Even though the Samuels paper focuses on the Brazilian political system, I will show that the same three hypotheses hold true for the United States Senate.

For purposes of estimation, I use a two-stage least squares vote share model based on Stratmann (2013) with one crucial deviation. In Stratmann's model, the first stage determines the factors important to the appropriation of earmarks. Then, using the results from the first stage, factors such as earmark appropriations, political affiliation, fundraising, past electoral success and experience are determined to be the main drivers of electoral success. I believe 
that the relationship between pork-barrel spending and fundraising occurs in the opposite direction. Therefore, I estimate the impact of pork-barrel spending on fundraising in the first stage and then, using the results from the first stage, estimate the factors which influence vote share. As an extension, I use simultaneous equations with a three stage least squares approach. The three-stage estimation method may be a useful extension due to the likely correlation of error term disturbances.

In addition to this differences in the first stage, this paper considers Senatorial elections over a period of five terms, whereas Stratmann's research focuses on the House of for a single election. But, even with the differences, the spirit of the analysis is similar to that of Stratmann (2013): there are factors which may influence an incumbent's ability to be re-elected, but some of the factors may only have an indirect impact.

\section{The Model}

In order to test the three hypotheses detailed earlier, I first estimate the following model:

$$
\text { Incumbent Election Percentage }=\beta_{0}+\beta_{1} \cdot \text { pork }+\beta_{2} \cdot \text { fundraising }+\beta_{3} \cdot X_{i}+\varepsilon_{i}
$$

where the dependent variable is the percentage of an incumbent's vote share in the general election, the pork variable is the amount of pork-barrel spending accumulated by the state, fundraising is the amount of money fundraised by the incumbent and $X_{i}$ is a vector of control variables which are discussed shortly. But, assuming that my first hypothesis is true, pork-barrel spending will not be significantly correlated with the incumbent's election percentage.

In addition, incumbents have incentives to respond to a tight race by increasing their fundraising. Therefore, fundraising may actually indicate electoral weakness. Because the actual "closeness" of the race is often unobserved and unmeasurable, the estimation of the 
fundraising variable may be biased downward. Therefore, an appropriate instrument must be used.

For an instrument to be valid, it cannot be correlated with the incumbent's vote share but must be correlated with campaign fundraising. I contend that pork-barrel spending can be used as an instrument. I test my first hypothesis that pork-barrel spending does not directly influence the incumbent's vote share. This would indicate that there is no correlation between the dependent variable and the instrument. Next, I test my second hypothesis that pork-barrel spending increases an incumbent's ability to fundraise. This verifies that the instrument is correlated with the variable being instrumented. As long as both hypotheses are verified, a two-stage least squares (2SLS) approach may be used.

The first-stage is estimated as

$$
\text { fundraising }=\delta_{0}+\delta_{1} \cdot \text { pork }+\delta_{2} z_{k}+\beta_{i} \cdot X_{i}+r_{k}
$$

where $z_{k}$ are other instruments used in this study, $X_{i}$ is the vector of variables exogenous to incumbent election percentage and $r_{k}$ is the error term. Then, the second stage is estimated as:

$$
\text { Incumbent Election Percentage }=\beta_{0}+\beta_{2} \cdot \text { fun } \widehat{\operatorname{dral}} \operatorname{sing}+\beta_{j} \cdot X_{i}+\varepsilon_{i} \text {. }
$$

Assuming that the instrumented variable is significant, the third hypothesis of this paper will hold verifying each of the three hypotheses.

As a test of robustness, I also consider a simultaneous equation approach using a three stage least squares (3SLS) regression is applicable. The two simultaneous equations used are

(1) fundraising $=\delta_{0}+\delta_{1} \cdot \operatorname{pork}+\delta_{2} z_{k}+r_{k}$

(2)Incumbent Election Percentage $=\beta_{0}+\beta_{2} \cdot$ fundraising $+\beta_{3} \cdot X_{i}+\varepsilon_{i}$. 


\section{Data}

Data on the incumbent was collected for all Senators vying for re-election from 2004-2012. The main independent variable is the Senator's fundraising in the current election. Two different measures of fundraising are used. First, the total amount of money fundraised during the current election cycle, in millions of dollars, is used. This allows for a straightforward analysis on the impact on fundraising on electoral success. In addition to the total amount fundraised, I also consider the percentage of total fundraising raised by the incumbent. For instance, if the incumbent raises $\$ 15$ million and the challenger raises $\$ 5$ million, then out of the combined $\$ 20$ million raised for this race, $75 \%$ is raised by the incumbent. Samuels (2002) and Stratmann (2013) see this treatment of fundraising as superior to a nominal total fundraising variable for several reasons. First, it allows for state-to-state comparisons. Second, population does not matter when the share of fundraising is used as it is simply a percentage of total fundraising. Third, price level differences do not matter. Because the spending in Senate campaigns can vary drastically, the fundraising advantage variable allows for a more straightforward comparison of Senate races.

In addition to the money raised during the current election cycle, cash-on-hand can also create an advantage for the incumbent as it represents monies which are carried over from a previous election cycle. Politicians can bank unused campaign contributions for use in future, more competitive races.

In order to account for the challenge faced by the incumbent, I also include the total amount fundraised by the incumbent's challenger. Generally speaking, as the amount of money raised by the challenger increases, the challenge faced by the incumbent increases as well. 
Characteristics of individual senators were also collected. First, I use a party binary variable which has a value of one if the Senator is a Democrat. While political affiliation is not likely to matter when it comes to fundraising, party affiliation is important in elections because voter policy preferences vary among the states. In addition, I also use a binary variable to account for the sex of the Senator. If the incumbent is a female, then the binary variable has a value of one. This variable is included due to the historical barriers of entry experienced by females, especially those associated with the upper house of Congress, which might affect their ability to secure targeted expenditures.

The number of terms variable measures the seniority of the Senator as the number of terms served in the Senate. As the number of terms increases, politicians gain more power in the Senate which can be leveraged into greater visibility. This gives the Senator an advantage over challengers, especially those without past experience. Because this variable only considers the Senator's experience in the Senate, I also include a binary variable which has a value of one if the Senator previously was a member of the House of Representatives.

Just as experience impacts electability, past success does as well. Thus, the percentage of the votes received in the previous Senate general election is used. With incumbency re-election rates at between 85 and 90 percent $^{14}$, Senators with past electoral success are likely to have similar successes in the future.

Finally, due to the use of state-level data, two modifications of the usual electoral models were required. Instead of representing a single district, a Senator represents an entire state with a second Senator which creates an opportunity for cooperation. Therefore, a binary

\footnotetext{
${ }^{14}$ This fact is also why a probit model cannot be used.
} 
variable is used which has a value of one if both Senators from the state belong to the same party. Second, because the dependent variable is the percentage of the vote received in the previous general election, only Senators who were elected to a full term are included. Therefore, Senators who entered office unelected or through a special election are not included. Since 2004, there are 117 incumbent who served full terms.

Because I use a two-stage regression, there are three instruments used to instrument the fundraising variables. The first is pork-barrel spending. Data on pork-barrel spending are taken from the Citizens Against Government Waste data set. Pork-barrel money appropriated to a state follows an electoral cycle. Instead of measuring the amount of pork-barrel spending appropriated to a state each year, I measure the amount of pork-barrel spending based on the number of years to the incumbent's re-election. Specifically, I use the yearly pork-barrel spending for the three years leading to the re-election ${ }^{15}$. Because it is impossible to distinguish between the individual efforts of each Senator, the total amount of pork-barrel spending appropriated by the state is used.

Second, the log of the population of the state is used as an instrument. The population is correlated with total fundraising as a larger population will lead to a greater number of potential donors. On the other hand, population is not correlated with the incumbent election percentage. Finally, time-effects are used to control for the year of the election in the first stage. I have shown that time effects are significant when estimating fundraising but I also found that time effects are not significant in the vote share regression. Therefore, time effects

\footnotetext{
${ }^{15}$ I discuss the reasoning in further depth as well as alternative approaches in the previous chapter.
} 
can be used as an instrument. The descriptive statistics and the sources of the data are included

in table 19.

Table 19: Descriptive Statistics for State-Level Regression

\begin{tabular}{|c|c|c|c|c|c|c|}
\hline Variable & Source & Obs. & Mean & St. Dev. & Min & Max \\
\hline Percent of Vote in General Election & FEC & 117 & 61.22 & 10.32 & 36.08 & 100 \\
\hline Incumbent Fundraising (millions of \$) & FEC & 117 & 10.762 & 7.481 & 1.444 & 51.567 \\
\hline Challenger Fundraising (millions of \$) & FEC & 117 & 4.060 & 5.847 & 0.001 & 28.162 \\
\hline Fundraising Advantage (in \%) & FEC & 117 & 81.354 & 17.416 & 36.222 & 99.992 \\
\hline Democrat* & Congress & 117 & 0.538 & 0.501 & 0 & 1 \\
\hline Number of Terms in Current Office & Congress & 117 & 2.521 & 1.705 & 1.000 & 8.000 \\
\hline Percentage of vote in previous general election & FEC & 117 & 60.876 & 9.316 & 47.880 & 99.000 \\
\hline Incumbent faced challenger in primary?* & FEC & 117 & 0.436 & 0.498 & 0.000 & 1.000 \\
\hline Both Senators belong to same party?* & Congress & 117 & 0.761 & 0.429 & 0 & 1 \\
\hline Cash-on-Hand (millions of dollars) & OpenSecrets & 117 & 1.726 & 2.918 & 0.000 & 17.800 \\
\hline House of Representatives* & Congress & 117 & 0.564 & 0.498 & 0.000 & 1.000 \\
\hline Female* & Congress & 117 & 0.197 & 0.399 & 0.000 & 1.000 \\
\hline Log(Population) & Census & 117 & 0.571 & 0.461 & -0.292 & 1.580 \\
\hline Pork-Barrel Funding during election year & CAGW & 117 & 166.427 & 151.641 & 0.000 & 733.634 \\
\hline Pork-Barrel Funding year prior & CAGW & 117 & 125.093 & 135.391 & 0.000 & 588.800 \\
\hline Pork-Barrel Funding two years prior & CAGW & 117 & 187.558 & 138.218 & 16.600 & 671.800 \\
\hline
\end{tabular}

Note: Variables marked with an asterisk are binary variables.

\subsection{Estimation and Analysis}

The dependent variable estimated is the percentage of the votes the incumbent received in the general election. To generate a baseline, the first set of regressions use a pooled ordinary least squares (OLS) approach. For each set of estimations, I run one regression with the total incumbent fundraising variable and one regression with the percent of incumbent fundraising variable. When the percent of fundraising advantage variable is used, the challenger fundraising variable and the log of the population variable are dropped.

In addition to the first two baseline regressions, I also run two pooled OLS regressions including the pork-barrel spending variables. The inclusion of these independent variables 
allows for the test of the first hypothesis: that pork-barrel spending does not directly help incumbents win elections. As long as pork-barrel spending is not correlated with incumbent vote share, both the first hypothesis and the acceptability of pork-barrel spending as an instrument will be verified.

Next, I repeat my first two regressions using the 2SLS approach. The first stage estimates the factors which impact political fundraising, including pork-barrel spending. The second stage uses the instrumented fundraising variable in addition to other factors to determine what factors influence the incumbent vote share. As a test of robustness, I repeat the two 2SLS regressions using a panel 2SLS approach.

Because of the relationships between pork-barrel spending, campaign fundraising and electoral success, a simultaneous equations approach that accounts for error dependencies may be appropriate. The two original regressions are thus re-estimated with a three stage least squares (3SLS) regression using the system of equations previously discussed. The three stage results also provide evidence of the robustness of the 2SLS estimates.

\section{OLS Baseline Results}

I begin by conducting a pooled ordinary least squares (OLS) to determine a baseline for the eventual two-stage and three-stage estimates. The results are displayed below in Table 20. In regressions 1 and 2, the total incumbent fundraising variable is not significant. As mentioned, the likely endogoneity associated with this variable can cause a downward bias creating a motivation for a two or three stage approach. In addition, the incumbent's performance in the last general election and cash on hand are both shown to be significant and positively related to electoral success. On the other hand, facing a challenger in the primary negatively impacts 
performance in the general election. This is likely because additional resources were required simply to make it into the general election.

Regressions 3 and 4 use the incumbent share of fundraising variable. In both of the regressions, the share of fundraising variable is shown to be both significant and positively correlated with vote share. Specifically, a $1 \%$ increase in the share of incumbent fundraising leads to a $0.33 \%$ increase in vote share. The other control variables discussed in the previous paragraph all maintain their relationship with the incumbent vote share variable.

Regressions 2 and 4 add pork-barrel spending variables to the baseline results to determine if they are correlated with electoral success. In general, pork-barrel spending is not correlated with electoral success. There is a relationship between pork-barrel spending one year before the election and electoral success, but this is effect is very small. In any case, there is evidence that pork-barrel spending is not directly correlated with the share of votes in Senate elections. This result supports the first hypothesis that pork-barrel spending does not directly help incumbents win elections. Subsequently, pork-barrel spending is an appropriate instrument due to the lack of correlation between it and electoral success. 
Table 20: Pooled OLS Regressions (Regressions 1-4)

\begin{tabular}{|c|c|c|c|c|}
\hline Variable & (1) & (2) & (3) & (4) \\
\hline Incumbent Fundraising Share & & & $0.333^{* * *}$ & $0.344^{* * *}$ \\
\hline (as \% of total fundraising) & & & $(0.044)$ & $(0.045)$ \\
\hline Total Incumbent Fundraising & -0.080 & -0.036 & & \\
\hline (millions of \$) & $(0.152)$ & (0.159) & & \\
\hline Total Challenger Fundraising & $-0.700 * * *$ & $-0.719 * * *$ & & \\
\hline (millions of \$) & $(0.184)$ & $(0.189)$ & & \\
\hline Democrat & 2.001 & 1.868 & 1.709 & 1.487 \\
\hline & $(1.520)$ & (1.554) & $(1.395)$ & (1.397) \\
\hline Number of Terms & -0.072 & 0.023 & -0.187 & -0.117 \\
\hline & $(0.525)$ & $(0.553)$ & $(0.485)$ & $(0.500)$ \\
\hline$\%$ of Vote in Previous Elec. & $0.258^{* *}$ & $0.255^{* *}$ & $0.250 * * *$ & $0.237^{* *}$ \\
\hline & $(0.102)$ & $(0.104)$ & $(0.091)$ & $(0.091)$ \\
\hline Challenged in Primary? & $\begin{array}{c}-5.696 * * * \\
(1.452)\end{array}$ & $\begin{array}{c}-5.775 * * * \\
(1.508)\end{array}$ & $\begin{array}{c}-4.901 * * * \\
(1.346)\end{array}$ & $\begin{array}{c}-4.713 * * * \\
(1.368)\end{array}$ \\
\hline Senators are in Same Party & $\begin{array}{c}0.502 \\
(1.776)\end{array}$ & $\begin{array}{c}0.777 \\
(1.818)\end{array}$ & $\begin{array}{l}-0.778 \\
(1.633)\end{array}$ & $\begin{array}{l}-0.266 \\
(1.646)\end{array}$ \\
\hline $\begin{array}{l}\text { Cash on Hand } \\
\text { (millions of } \$ \text { ) }\end{array}$ & $\begin{array}{l}0.691^{* *} \\
(0.299)\end{array}$ & $\begin{array}{l}0.686 * * \\
(0.308)\end{array}$ & $\begin{array}{l}0.288 \\
(0.240)\end{array}$ & $\begin{array}{l}0.298 \\
(0.249)\end{array}$ \\
\hline House of Representatives & $\begin{array}{c}0.560 \\
(1.473)\end{array}$ & $\begin{array}{c}0.455 \\
(1.571)\end{array}$ & $\begin{array}{l}-0.174 \\
(1.366)\end{array}$ & $\begin{array}{l}-0.742 \\
(1.440)\end{array}$ \\
\hline Female & $\begin{array}{l}-2.292 \\
(1.983)\end{array}$ & $\begin{array}{l}-1.826 \\
(2.107)\end{array}$ & $\begin{array}{l}-2.006 \\
(1.777)\end{array}$ & $\begin{array}{l}-1.292 \\
(1.867)\end{array}$ \\
\hline $\begin{array}{l}\text { Pork Election Year } \\
\text { (millions of \$) }\end{array}$ & & $\begin{array}{l}-0.005 \\
(0.008)\end{array}$ & & $\begin{array}{l}-0.011 \\
(0.007)\end{array}$ \\
\hline $\begin{array}{l}\text { Pork Year Before Election } \\
\text { (millions of \$) }\end{array}$ & & $\begin{array}{c}0.005 \\
(0.008)\end{array}$ & & $\begin{array}{l}0.012^{*} \\
(0.007)\end{array}$ \\
\hline $\begin{array}{l}\text { Pork Two Yr Before Election } \\
\text { (millions of \$) }\end{array}$ & & $\begin{array}{l}-0.004 \\
(0.008)\end{array}$ & & $\begin{array}{l}-0.004 \\
(0.008)\end{array}$ \\
\hline Constant & $\begin{array}{l}49.346 \\
(5.911) \\
\end{array}$ & $\begin{array}{r}49.68 \\
(6.041) \\
\end{array}$ & $\begin{array}{l}21.175 \\
(5.477) \\
\end{array}$ & $\begin{array}{l}21.889 \\
(5.680) \\
\end{array}$ \\
\hline Observations & 117 & 117 & 117 & 117 \\
\hline R-squared & 0.507 & 0.451 & 0.577 & 0.598 \\
\hline F-statistic & $10.88^{* * *}$ & $8.34^{* * *}$ & $16.18 * * *$ & $12.88^{* * *}$ \\
\hline
\end{tabular}

Standard errors in parentheses: $* * *=1 \%, * *=5 \%, *=10 \%$ significance level

\section{Two Stage Least Squares (TSLS) Results}

Regressions 5 and 7 use a two-stage least squares approach. Both the first and second stage results are given below. The first stage results, shown in table 21, are similar to the results from the previous chapter. Without spending too much time on the first-stage results, the key outcome is that pork-barrel spending in the election year is significant and positively correlated with total fundraising and incumbent fundraising share. Because pork-barrel spending is 
correlated with fundraising but not with electoral performance, pork-barrel spending may be used as an instrument. The other control variables also function in the same way that they did in the previous chapter of this dissertation.

The second stage results, shown in table 22 , continue to show the control variables behaving in much the same way they did in the pooled OLS regressions. In addition, they illustrate that there is a relationship between fundraising share and electoral performance even though there is no direct relationship between total fundraising and electoral performance. The lack of significance is likely due to the fact that both incumbent fundraising and challenger fundraising are used to estimate the incumbent's share of the vote. While they both are related to electoral performance, they also likely are correlated with each other leading to bias in the estimates. On the other hand, both incumbent and challenger fundraising are incorporated into the incumbent's share of fundraising. As mentioned earlier, Samuels (2002) and Stratmann (2013) both use share of fundraising which is likely due to the advantages discussed earlier.

The results from regression 6 support the last two hypotheses of the paper. The first stage illustrates that pork-barrel spending is positively correlated with fundraising. Then, the second stage shows the positive correlation between share of fundraising and share of votes in the general election. Also, recalling that I showed that pork-barrel spending is not correlated with electoral success, I have effectively proven all three of the hypotheses I stated earlier in the paper. Politicians are able to increase their share of the vote through the use of pork-barrel spending, but not directly. Politicians can use pork-barrel spending to increase their fundraising which can then be used to increase their chances of being re-elected. 
Table 21: 2SLS First Stage Results (Regressions 5-8)

\begin{tabular}{|c|c|c|c|c|}
\hline \multirow{2}{*}{$\begin{array}{l}\text { Dependent Variable } \\
\text { Variable }\end{array}$} & \multicolumn{2}{|c|}{ Total Incumbent Fundraising } & \multicolumn{2}{|c|}{ Share of Inc. Fundraising } \\
\hline & (5) & (6) & (7) & (8) \\
\hline Pork Election Year & $0.015^{* *}$ & $0.023 * * *$ & 0.026 & 0.026 \\
\hline (millions of \$) & $(0.006)$ & $(0.006)$ & $(0.020)$ & $(0.020)$ \\
\hline Pork Year Before Election & 0.005 & -0.002 & $-0.051 * *$ & -0.051 \\
\hline (millions of \$) & $(0.006)$ & $(0.007)$ & $(0.021)$ & $(0.021)$ \\
\hline Pork Two Yr Before Election & $-0.018 * * *$ & -0.003 & -0.012 & -0.013 \\
\hline (millions of \$) & $(0.007)$ & $(0.013)$ & $(0.021)$ & $(0.021)$ \\
\hline Log(Population) & $\begin{array}{c}5.410 * * * \\
(1.273)\end{array}$ & & & \\
\hline $\begin{array}{l}\text { Total Challenger Fundraising } \\
\text { (millions of \$) }\end{array}$ & $\begin{array}{c}0.740 * * * \\
(0.080)\end{array}$ & $\begin{array}{c}0.707^{* * *} \\
(0.086)\end{array}$ & & \\
\hline Democrat & $\begin{array}{c}0.014 \\
(0.904)\end{array}$ & $\begin{array}{l}-1.995 \\
(1.546)\end{array}$ & $\begin{array}{l}-1.851 \\
(3.123)\end{array}$ & $\begin{array}{l}-1.941 \\
(3.162)\end{array}$ \\
\hline Number of Terms & $\begin{array}{c}0.201 \\
(0.324)\end{array}$ & $\begin{array}{c}0.877^{* *} \\
(0.394)\end{array}$ & $\begin{array}{c}1.766 \\
(1.096)\end{array}$ & $\begin{array}{c}1.758 \\
(1.103)\end{array}$ \\
\hline \% of Vote in Previous Elec. & $\begin{array}{c}-0.127^{* *} \\
(0.058)\end{array}$ & $\begin{array}{c}-0.184^{* *} \\
(0.077)\end{array}$ & $\begin{array}{l}0.175 \\
(0.200)\end{array}$ & $\begin{array}{c}0.169 \\
(0.202)\end{array}$ \\
\hline Faced Challenger in Primary? & $\begin{array}{l}0.605 \\
(0.899)\end{array}$ & $\begin{array}{l}1.087 \\
(0.958)\end{array}$ & $\begin{array}{l}-3.769 \\
(3.128)\end{array}$ & $\begin{array}{l}-3.665 \\
(3.125)\end{array}$ \\
\hline Senators are in Same Party & $\begin{array}{c}0.360 \\
(1.061)\end{array}$ & $\begin{array}{c}0.795 \\
(1.640)\end{array}$ & $\begin{array}{l}7.782 * * \\
(3.586)\end{array}$ & $\begin{array}{c}7.772 \\
(3.633)\end{array}$ \\
\hline $\begin{array}{l}\text { Cash on Hand } \\
\text { (millions of \$) }\end{array}$ & $\begin{array}{c}0.813^{* * *} \\
(0.157)\end{array}$ & $\begin{array}{c}0.356 \\
(0.269)\end{array}$ & $\begin{array}{c}1.997^{* * *} \\
(0.517)\end{array}$ & $\begin{array}{c}2.021 \\
(0.527)\end{array}$ \\
\hline House of Representatives & $\begin{array}{l}0.327 \\
(0.924)\end{array}$ & $\begin{array}{l}2.041^{*} \\
(1.147)\end{array}$ & $\begin{array}{l}5.853^{*} \\
(3.192)\end{array}$ & $\begin{array}{r}5.880 \\
(3.209)\end{array}$ \\
\hline Female & $\begin{array}{l}2.238^{*} \\
(1.200)\end{array}$ & $\begin{array}{l}6.136^{* *} \\
(1.705)\end{array}$ & $\begin{array}{c}0.839 \\
(4.155)\end{array}$ & $\begin{array}{l}1.030 \\
(4.201)\end{array}$ \\
\hline 2006 Election & $\begin{array}{c}0.700 \\
(1.245)\end{array}$ & $\begin{array}{l}0.458 \\
(1.294)\end{array}$ & $\begin{array}{l}-6.108 \\
(4.285)\end{array}$ & $\begin{array}{l}-6.132 \\
(4.264)\end{array}$ \\
\hline 2008 Election & $\begin{array}{l}1.750 \\
(1.582)\end{array}$ & $\begin{array}{c}2.349 \\
(1.650)\end{array}$ & $\begin{array}{l}-8.366 \\
(5.457)\end{array}$ & $\begin{array}{l}-8.436 \\
(5.443)\end{array}$ \\
\hline 2010 Election & $\begin{array}{c}1.434 \\
(1.413)\end{array}$ & $\begin{array}{c}1.444 \\
(1.353)\end{array}$ & $\begin{array}{l}-2.662 \\
(4.855)\end{array}$ & $\begin{array}{l}-2.844 \\
(4.820)\end{array}$ \\
\hline 2012 Election & $\begin{array}{c}4.917 * * * \\
(2.024)\end{array}$ & $\begin{array}{c}5.911^{* * *} \\
(2.088)\end{array}$ & $\begin{array}{l}-6.288 \\
(6.981)\end{array}$ & $\begin{array}{l}-6.500 \\
(6.963)\end{array}$ \\
\hline Constant & $\begin{array}{c}8.139 \\
(3.499) \\
\end{array}$ & $\begin{array}{c}9.383 \\
(4.885) \\
\end{array}$ & $\begin{array}{c}65.219 \\
(11.748) \\
\end{array}$ & $\begin{array}{c}65.742 \\
(11.839) \\
\end{array}$ \\
\hline Observations & 117 & 117 & 117 & 117 \\
\hline R-squared & 0.711 & 0.705 & 0.342 & \\
\hline F/Wald-statistic & $14.34 * * *$ & $7.78 * * *$ & $3.50 * * *$ & $51^{* * *}$ \\
\hline Dependent Variable & Total Incu & undraising & Share of & draising \\
\hline
\end{tabular}

Standard errors in parentheses: $* * *=1 \%, * *=5 \%, *=10 \%$ significance level 
Table 22: 2SLS Second Stage Results (Regressions 5-8)

\begin{tabular}{|c|c|c|c|c|}
\hline Variable & (1) & (2) & (3) & (4) \\
\hline Incumbent Fundraising Share & & & $0.249^{* *}$ & $0.255^{*}$ \\
\hline (as \% of total fundraising) & & & $(0.131)$ & (0.137) \\
\hline Total Incumbent Fundraising & -0.135 & 0.179 & & \\
\hline (millions of \$) & $(0.293)$ & $(0.484)$ & & \\
\hline Total Challenger Fundraising & $-0.653 * *$ & $-0.923 * *$ & & \\
\hline (millions of \$) & $(0.279)$ & (0.409) & & \\
\hline \multirow[t]{2}{*}{ Democrat } & 1.994 & -0.179 & 1.510 & 1.430 \\
\hline & (1.448) & (3.016) & (1.389) & (1.467) \\
\hline \multirow[t]{2}{*}{ Number of Terms } & -0.067 & 0.417 & -0.093 & -0.083 \\
\hline & $(0.501)$ & $(0.861)$ & $(0.491)$ & $(0.518)$ \\
\hline \multirow[t]{2}{*}{ \% of Vote in Previous Elec. } & $0.249 * *$ & 0.019 & $0.273^{* * *}$ & $0.263 * * *$ \\
\hline & $(0.105)$ & $(0.178)$ & $(0.095)$ & (0.099) \\
\hline \multirow[t]{2}{*}{ Faced Challenger in Primary? } & $-5.651 * * *$ & $-5.189 * * *$ & $-5.329 * * *$ & $-5.301 * * *$ \\
\hline & (1.399) & $(2.022)$ & $(1.456)$ & $(1.513)$ \\
\hline \multirow[t]{2}{*}{ Senators are in Same Party } & 0.610 & 1.980 & -0.115 & -0.121 \\
\hline & (1.764) & (3.530) & $(1.870)$ & $(1.971)$ \\
\hline \multirow{2}{*}{ Cash on Hand } & $0.749 *$ & 0.942 & 0.441 & 0.443 \\
\hline & $(0.395)$ & (0.598) & $(0.327)$ & $(0.347)$ \\
\hline \multirow[t]{2}{*}{ House of Representatives } & 0.560 & 0.444 & 0.145 & 0.107 \\
\hline & (1.403) & (2.217) & (1.411) & (1.478) \\
\hline \multirow[t]{2}{*}{ Female } & -2.124 & -3.782 & -2.095 & -2.172 \\
\hline & (2.046) & (4.365) & $(1.733)$ & (1.834) \\
\hline \multirow[t]{2}{*}{ Constant } & 50.042 & 60.527 & 25.710 & 25.906 \\
\hline & (6.503) & $(10.436)$ & (8.592) & (9.016) \\
\hline Observations & 117 & 117 & 117 & 117 \\
\hline R-squared & 0.506 & 0.421 & 0.562 & 0.483 \\
\hline Wald-statistic & $119.89 * * *$ & $7,088^{* * *}$ & $95.60 * * *$ & $85.29 * * *$ \\
\hline
\end{tabular}

Standard errors in parentheses: $* * *=1 \%, * *=5 \%, *=10 \%$ significance level

\section{Panel TSLS Results}

Next, I repeat the previous set of two-stage regressions in a panel setting. Regression 6

is the panel treatment of regression 5 while regression 8 is the panel treatment of regression 7.

The first stage results are displayed in table 3 while the second stage results are displayed in

table 4. The Hausman Test indicates that fixed-effects should be used when the dependent

variable is total incumbent fundraising and that random-effects should be used when the dependent variable is the incumbent's share of total fundraising. The Hausman Test results are given in table 23. 


\section{Table 23: Hausman Test Results}

\begin{tabular}{|c|c|}
\hline \multicolumn{1}{|c|}{ Dependent Variable } & Chi-Squared Statistic \\
\hline $\begin{array}{c}\text { Total Incumbent Fundraising } \\
\text { Incumbent Share of Fundraising }\end{array}$ & $31.21^{* * *}$ \\
8.15 \\
\hline $\begin{array}{l}\mathrm{H}_{0}: \text { A random effects model should be used. } \\
* * *=\mathbf{1 \%}, * *=\mathbf{5 \% , *}=\mathbf{1 0 \%} \text { significance level }\end{array}$ \\
\hline
\end{tabular}

In general, the results are very similar to the pooled 2SLS estimates. This demonstrates that the estimates are robust to changes in the estimation approach. Just as before, the share of incumbent fundraising is both significant and positively correlated with electoral success while total fundraising is not. In addition, challenger fundraising and a primary election challenger are both negatively correlated with general election performance while previous election performance is positively correlated with the incumbent's share of votes.

\section{SLS Regression Results}

Finally, I repeat the estimation using a simultaneous equations framework. The results are given below in tables 24 and 25 . The first table gives the results for the vote share regressions while the second table gives the results for the fundraising regressions.

The results for the set of regressions which use total incumbent fundraising are essentially identical under both the 2SLS and 3SLS frameworks. Therefore, I will not discuss them at any more length. The results for the set of regressions which use the share of fundraising do differ to some degree, but only within the fundraising regression. Pork-barrel spending, specifically during the election year, is shown to be significant and positively correlated with the incumbent's share of fundraising and the incumbent's share of fundraising is shown to be significant and positively correlated with the incumbent's share of the votes in the general election. This once again reaffirms the main thesis of this paper that pork-barrel spending does 
increase the likelihood of being re-elected, but indirectly. If pork-barrel spending is properly timed and funneled to concentrated groups, the legislator responsible for the federal money can be rewarded with additional campaign contributions. The additional contributions allow the incumbent to increase their campaign reach which in turn increases the percentage of the votes they receive in the general election.

Table 24: 3SLS First Stage Results (\% of Vote in General Election)

\begin{tabular}{|l|cc|}
\hline \multicolumn{3}{|l|}{ Equation 1 Dependent Variable: Incumbent's Share of Votes } \\
\hline Variable & $(9)$ & $(10)$ \\
Incumbent Fundraising Share & & $0.250^{* *}$ \\
(as \% of total fundraising) & & $(0.131)$ \\
Total Incumbent Fundraising & -0.135 & \\
(millions of \$) & $(0.293)$ & \\
Total Challenger Fundraising & $-0.653^{* *}$ & \\
(millions of \$) & $(0.279)$ & \\
Democrat & 1.992 & 1.657 \\
& $(1.447)$ & $(1.365)$ \\
Number of Terms & -0.067 & -0.107 \\
& $(0.501)$ & $(0.491)$ \\
\% of Vote in Previous Elec. & $0.249 * *$ & $0.275^{* * *}$ \\
& $(0.105)$ & $(0.095)$ \\
Faced Challenger in Primary? & $-5.652^{* * *}$ & $-5.314^{* * *}$ \\
& $(1.399)$ & $(1.456)$ \\
Senators are in Same Party & 0.610 & -0.111 \\
& $(1.764)$ & $(1.870)$ \\
Cash on Hand & $0.749 *$ & 0.438 \\
(millions of \$) & $(0.395)$ & $(0.327)$ \\
House of Representatives & 0.560 & 0.135 \\
& $(1.403)$ & $(1.411)$ \\
Female & -2.123 & -2.143 \\
& $(2.046)$ & $(1.731)$ \\
Constant & 50.044 & 25.532 \\
& $(6.503)$ & $(8.586)$ \\
\hline R-Squared & 0.506 & 0.562 \\
Chi-Squared Value & $119.89 * * *$ & $95.81 * * *$ \\
\hline
\end{tabular}

Standard errors in parentheses:

$* * *=1 \%, * *=5 \%, *=10 \%$ significance level 
Table 25: 3SLS Equation 2 Result (Fundraising)

\begin{tabular}{|c|c|c|}
\hline Equation 2 Results & $\begin{array}{l}\text { Total Incumbent } \\
\text { Fundraising }\end{array}$ & $\begin{array}{l}\text { Share of } \\
\text { Fundraising }\end{array}$ \\
\hline Variable & $(11)$ & (12) \\
\hline $\begin{array}{l}\text { Pork Election Year } \\
\text { (millions of \$) }\end{array}$ & $\begin{array}{c}0.015^{* * *} \\
(0.005)\end{array}$ & $\begin{array}{l}0.028^{*} \\
(0.019)\end{array}$ \\
\hline $\begin{array}{l}\text { Pork Year Before Election } \\
\text { (millions of } \$ \text { ) }\end{array}$ & $\begin{array}{c}0.005 \\
(0.006)\end{array}$ & $\begin{array}{c}-0.054^{* * *} \\
(0.019)\end{array}$ \\
\hline $\begin{array}{l}\text { Pork Two Yr Before Election } \\
\text { (millions of \$) }\end{array}$ & $\begin{array}{c}-0.018^{* * *} \\
(0.006)\end{array}$ & $\begin{array}{l}-0.009 \\
(0.019)\end{array}$ \\
\hline Log(Population) & $\begin{array}{c}5.396^{* * *} \\
(1.170)\end{array}$ & \\
\hline $\begin{array}{l}\text { Total Challenger Fundraising } \\
\text { (millions of \$) }\end{array}$ & $\begin{array}{c}0.740^{* * *} \\
(0.073)\end{array}$ & \\
\hline Number of Terms & $\begin{array}{c}0.199 \\
(0.286)\end{array}$ & $\begin{array}{l}1.510 \\
(0.981)\end{array}$ \\
\hline$\%$ of Vote in Previous Elec. & $\begin{array}{c}-0.127^{* *} \\
(0.053)\end{array}$ & $\begin{array}{l}0.204 \\
(0.184)\end{array}$ \\
\hline Faced Challenger in Primary? & $\begin{array}{c}0.597 \\
(0.824)\end{array}$ & $\begin{array}{l}-3.917 \\
(2.895)\end{array}$ \\
\hline Senators are in Same Party & $\begin{array}{c}0.355 \\
(0.976)\end{array}$ & $\begin{array}{c}7.726 * * \\
(3.329)\end{array}$ \\
\hline $\begin{array}{l}\text { Cash on Hand } \\
\text { (millions of \$) }\end{array}$ & $\begin{array}{c}0.814^{* * *} \\
(0.144)\end{array}$ & $\begin{array}{c}1.957 * * * \\
(0.479)\end{array}$ \\
\hline House of Representatives & $\begin{array}{l}0.329 \\
(0.849)\end{array}$ & $\begin{array}{l}5.764^{* *} \\
(2.960)\end{array}$ \\
\hline Female & $\begin{array}{l}2.241^{* *} \\
(1.070)\end{array}$ & $\begin{array}{l}-0.040 \\
(3.746)\end{array}$ \\
\hline 2006 Election & $\begin{array}{c}0.698 \\
(1.142)\end{array}$ & $\begin{array}{l}-5.909 \\
(3.922)\end{array}$ \\
\hline 2008 Election & $\begin{array}{l}1.812 \\
(1.454)\end{array}$ & $\begin{array}{l}-7.322 \\
(5.002)\end{array}$ \\
\hline 2010 Election & $\begin{array}{l}1.433 \\
(1.294)\end{array}$ & $\begin{array}{l}-1.814 \\
(4.426)\end{array}$ \\
\hline 2012 Election & $\begin{array}{c}4.878^{* * *} \\
(1.845)\end{array}$ & $\begin{array}{l}-7.028 \\
(6.311)\end{array}$ \\
\hline Constant & $\begin{array}{c}8.109 \\
(3.154)\end{array}$ & $\begin{array}{c}62.507 \\
(10.636)\end{array}$ \\
\hline R-Squared & 0.711 & 0.338 \\
\hline $\begin{array}{l}\text { Chi-Squared } \\
\text { Observations }\end{array}$ & $\begin{array}{l}288.19 * * * \\
117\end{array}$ & $60.50 * * *$ \\
\hline
\end{tabular}

Standard errors in parentheses:

$* * *=1 \%, * *=5 \%, *=10 \%$ significance level

\subsection{Conclusion}

Overall, three related hypotheses based on Samuels (2002) are tested in this paper. First, pork-barrel spending does not directly help incumbents win elections. This was demonstrated 
when pork-barrel spending was shown to be statistically unrelated to an incumbent's vote share. Second, pork-barrel spending increases an incumbent's ability to fundraise. This was verified both in the previous chapter of the dissertation as well as the first stage of the twostage regressions. Specifically, pork-barrel money appropriated in the election year is shown to be positively correlated with incumbent fundraising. Third, campaign funds help incumbents win reelection. This is verified in the second stage of the regressions in addition to an array of previous literature.

Once the three hypotheses are combined, a clearer picture presents itself. Incumbents are able to increase their chances of winning re-election by using pork-barrel spending but not directly. Instead, they can use pork-barrel spending to increase their ability to fundraise. That additional money can then be used to increase their chances of being reelected. This additional link is likely why researchers have had difficulty in connecting pork-barrel spending to electoral success even if the connection seems logical. This result is analogous with the results from the Brazilian political system as demonstrated by David Samuels (2002.)

In the previous chapter I found that a ten million dollar increase in pork-barrel spending leads to a $0.36 \%$ increase in the share of fundraising. In this paper, I find that a $1 \%$ increase in fundraising share leads to approximately a $0.25 \%$ increase in vote share. Therefore, the $\$ 10$ million increase in pork-barrel spending will lead to a $0.10 \%$ increase in the share of the vote in an election. In close elections, this could very easily be the difference between winning and losing an election. Also, considering that the average pork-barrel spending per state in an election year was \$104 million, incumbents can increase their chances of re-election by $1.04 \%$. From 2004 to 2012 there have been a total of nine Senate races decided by less than $1.04 \%$. 
This is not to say that even one of those races was decided because of pork-barrel spending; instead, this is evidence that there are multiple races that are within the margin that could be created if a legislator uses pork-barrel spending properly. 


\title{
Chapter 5: Pork-Barrel Spending and the Tragedy of the Commons
}

\begin{abstract}
This chapter concludes the dissertation by qualitatively considering pork-barrel spending as a common resource. Further, I summarize the results from the earlier chapters of this dissertation.
\end{abstract}

\subsection{Pork-Barrel Spending as a Common Resource}

A common resource is a commodity which is non-excludable but is rival. While no person can be excluded from using the good, increased consumption of the good results in less of that good being available for others. Common resources suffer from the Tragedy of the Commons which is the tendency for common resources to be overused and eventually depleted. Some traditional examples of the Tragedy of the Commons are the overhunting of the buffalo in America during the 1800 's, overfishing in public waters, and the deforestation of the rain forest. Earmark or pork-barrel spending is said to suffer from the same problem, referred to as the Fiscal Commons problem. Based on the work in this dissertation, it seems as though pork-barrel spending does in fact suffer from this problem.

In order to conceptualize this issue from a political framework, I use a generalized 2-player payout structure. Using a two-region framework, suppose that legislators from Region A and Region B both must make the decision whether or not to accept pork-barrel money. Further, suppose that a district receives $a+4$ if the legislator accepts the money but a -6 if the legislator from the other district accepts money. The payouts are as follows: 
Reg. B

\begin{tabular}{|c|c|c|}
\hline (Reg. A Payout, Reg. B Payout) & Earmark Spending & Refuse Earmark Spending \\
\hline Earmark Spending & $(-2,-2)$ & $(4,-6)$ \\
\hline Refuse Earmark Spending & $(-6,4)$ & $(0,0)$ \\
\hline
\end{tabular}

Figure 5: Game Theory Setup of Fiscal Commons Problem

The dominant strategy in this game setup is for both regions to engage in earmark spending. While this strategy does not maximize welfare, it does guarantee that the district avoids the situation in which they pay for other's projects yet receive no benefits at all. Intuitively, this would be the situation where a legislator passes on receiving extra funding for her district while a neighboring district receives the additional earmark money. The important thing to remember is that every district pays for the project regardless of whether or not they actually accept any funding. This creates the incentive for a politician to accept earmark funding regardless of the total impact on social welfare. In reality, there are two distinct problems with the previous simplistic setup. First, the game assumes that earmark spending is socially inefficient. Even though public opinion supports this idea, there is no concrete evidence to prove it. Secondly, total social welfare is difficult to measure. Therefore, I must be cautious when using my results to make any determination of a fiscal commons problem.

\subsection{Literature Pertaining to the Fiscal Commons Problem}

There is a growing amount of literature pertaining to the fiscal commons problem. While it has been long-recognized that common resources experience the Tragedy of the Commons, more recent research has focused on this problem in the public sector. It has even been noted that public policy meant to avoid the common resource problem exacerbates the problem the policy was designed to prevent (Ostrom, Walker et al. 1992). In general, consumers demand 
much more of a good if someone else is paying. This allows politicians to make decisions in much greater haste and without regard to budgetary sustainability (Caplan 2007). In addition, the political process is even more susceptible to the common resource problem as politicians not only have the ability to redistribute wealth between income groups and geographic areas, but they also have the ability to transfer wealth from the future to the present through the use of debt-financing (Buchanan 1958).

Ostrom, along with others, formalize the methodology required for properly managing common resources in a way to avoid the common resource problem (Ostrom 1990; Ostrom, Walker et al. 1992; Ostrom, Gardner et al. 1994; Ostrom and Walker 1997; Ostrom 1998; Jakee and Turner 2002). Firstly, there must be a broad consensus on sustainable levels of overall use. Secondly, there must be some generally agreed upon principle pertaining to who has access to the common good and in which capacity. Thirdly, there must be an efficient monitoring system to ensure the levels of access mentioned in the previous condition are being met. Finally, there must be effective and practical penalties imposed on those that violate the agreement (Ostrom 1990).

Jakkee and Turner boil the common resource problem down to two main causes. First of all, an institution must be able to limit the free-rider problem. At the heart of the common resource problem is the free-rider problem. Because rational individuals pursue their own selfinterests, they have an incentive to receive a good for free regardless of the impact on total social welfare. Secondly, an effective institution works to reduce the information problem. Traditionally, the information problem is the inability to fully coordinate activity causing asymmetric information between economic players. One common solution is to centralize 
information and decision-making, but this centralization is believed to create larger problems as the power of spontaneous order is harnessed (Hayek 1937). Further, it is not feasible for each individual to fully recognize all available options which are made available to them (Simon 1982; Simon 1984). This problem, known as bounded rationality, also implies that individuals are not fully aware of the decisions being made around them. Again, one possible solution to this is centralized knowledge, but this is typically expensive, time-consuming and inefficient. Not only does the asymmetric information create inefficient decision-making, but, as mentioned, it typically spawns more social institutions which are meant to combat the problem (Hayek 1973; Heiner 1983; Vanberg 1994; Ostrom 1998; Jakee and Turner 2002).

Earmark legislation suffers a similar fate. When comparing earmark legislation to the sustainability guidelines set forth by Ostrom, half of the criteria are met. For instance, the first criterion is that there must be a broad consensus on appropriate usage of the resource, which in this case is pork-barrel spending. In a previous literature review, one conclusion was that the optimal amount of earmark spending was zero, yet money is spent nonetheless (Primo and Snyder 2010). Therefore, the first criterion is met as there is a general consensus that distributive spending should be zero. The third criterion, pertaining to monitoring, is also met due to recent legislation requiring legislators to attach their name to any pork-barrel money they obtain. On the other hand, the second criteria, dealing with the access to the common good, should not matter as no one should have access. But, this is clearly not the case as earmark spending is far from zero. Further, there is no punishment mechanism for those who actually engage in earmark legislation. In fact, if my research is correct indicating obtaining earmark spending does increase the likelihood of being re-elected, not engaging in pork-barrel 
spending can actually act as a punishment. Thus, it is clear that the goals of the legislator and the goals of the constituents in a district are different.

\subsection{Primary Findings}

In chapter 2, I focus on the impact that pork-barrel spending has on job creation. Ultimately, I find that pork-barrel spending does create some short-term job creation but many of those jobs disappear after only one year. I also find, using a spatial analysis, that pork-barrel spending in one state can shift employment out of surrounding states. Thus, one state's increase in porkbarrel spending can have a negative impact on neighboring states. This both fits into the theoretical game theory setup described earlier as well as the definition of the fiscal commons problem. Therefore, chapter 2 does provide evidence of a fiscal commons problem.

Chapter 3 examines the impact pork-barrel spending has on fundraising. I find that porkbarrel spending does have a positive and significant impact on an incumbent's ability to fundraise. Therefore, incumbents do have the incentive to appropriate pork-barrel money into their state for their own purposes. This can be done by funneling money to special interests who, in turn, contribute to an incumbent's campaign. While this does not necessarily prove that this is the incumbent's aim when appropriating the funds, the incentive nonetheless exists.

Finally, chapter 4 uses the work from chapter 3 and uses a two-stage approach. In this chapter, I find that fundraising does have a positive impact on re-electability and that porkbarrel spending has a positive impact on fundraising. Therefore, while pork-barrel spending does not have a direct impact on a Senator's re-election chances, pork-barrel spending does have an indirect impact and can assist the Senate in his or her re-election bid. Again, this paper 
does not prove that this type of action actually does exist, only that Senators have the ability and incentive to engage in this type of action.

Ultimately, there is evidence that pork-barrel spending does indeed create a fiscal commons problem. Between the negative impact the spending has on other states and the incentive Senators have to use the funding for their own benefit, the opportunity for abuse exists. While more work would need done to prove that Senators are actually engaging in this abuse, anecdotal evidence would seem to support that this type of activity does occur. 


\section{References}

Abrams, B. A. and R. F. Settle (2004). "Campaign-Finance Reform: A Public Choice Perspective." Public Choice 120(3-4): 379-400.

Alford, J. and D. W. Brady (1981). "Increased Incumbency Advantage in the House." Journal of Politics 43: 1042-1061.

Alford, J. and R. G. Niemi (1989). Personal and Partisan Advantage in US Congressional Elections. Congress Reconsidered. L. C. Dodd and B. I. Oppenheimer. Washington DC, CQ Press.

Alt, J. E. (1985). "Political Parties, World Demand, and Unemployment: Domestic and International Sources of Economic Activity." The American Political Science Review 79(4): 1016-1040.

Anselin, L., A. K. Bera, et al. (1996). "Simple Diagnostic Tests for Spatial Dependence." Regional Science and Urban Economics 26: 77-104.

Anselin, L., J. LeGallo, et al. (2008). Chapter 19: Spatial Panel Econometrics, Springer Link.

Ansolabehere, S., D. W. Brady, et al. (1988). "The vanishing Marginals and Electoral Responsiveness." British Journal of Political Science 22: 21-38.

Ansolabehere, S., J. M. de Figueiredo, et al. (2003). "Why is there so little money in U.S. Politics?" Journal of Economic Perspectives 17(1): 105-130.

Ansolabehere, S., J. M. Synder, et al. (2000). "Old Voters, New Voters, and the Personal Vote: Using Redistricting to Measure the Incumbency Advantage." American Journal of Political Science 44(1): 17-34.

Balla, S. J., E. D. Lawrence, et al. (2002). "Partisanship, Blame Avoidance, and the Distribution of Legislative Pork." American Journal of Political Science: 515-525.

Ban-Zion, U. and Z. Eytan (1975). "On Money, Votes and Policy in a Democratic Society." Public Choice 17: 1-10.

Beaudry, P., D. A. Green, et al. (2007). Spill-Overs from Good Jobs. Working Paper No. 13006. NBER.

Bender, B. and J. R. Lott (1996). "Legislator voting and shirking: A critical review of the literature." Public Choice: 67-100.

Bickers, K. N. and R. M. Stein (1996). "The Electoral Dynamics of the Federal Pork Barrel." American Journal of Political Science: 27-40.

Binder, S. A. (1997). "The Partisan Basis of Procedural Choice: Allocating Parliamentry Rights in the House." American Political Science Review: 8-20.

Blumenthal, P., H. Wolman, et al. (2009). "Understanding the Economic Performance of Metropolitan Areas in the United States." Urban Studies 46: 605-627. 
Boas, T. C., F. D. Hidalgo, et al. (2014). "The Spoils of Victory: Campaign Donations and Government Contracts in Brazil." Journal of Politics Forthcoming.

Bonneau, C. W. (2007). "Campaign Fundraising in State Supreme Court Elections." Social Science Quarterly 88(1): 68-85.

Born, R. (1979). "Generational Replacement and the Growth of Incumbent Reelection Margins in the US House." American Political Science Review 18: 270-286.

Brams, S. J. and P. C. Fishburn (1996). "Minimal winning coalitions in weighted-majority voting games." Social Choice and Welfare 13(4): 397-417.

Buchanan, J. (1958). Public Principles of Public Debt. Homewood, IL.

Cain, B. E., J. A. Ferejohn, et al. (1987). The Personal Vote. Cambridge MA, Harvard University Press.

Caplan, B. (2007). Yhe Myth of the Rational Voter. Princeton, NJ, Princeton University Press.

Card, D. (1999). The Casual Effect of Education on Earnings. Handbook of Labor Economics 3, 1801-1863.

Collie, M. P. (1981). "Incumbency, Electoral Safety, and Turnover in the House of Representatives, 19521976." American Political Science Review 75: 119-131.

Congleton, R. D. (2006). "The Story of Katrina: New Orleans and the Political Economy of Catastrophe." Public Choice 127(1): 5-30.

Cover, A. D. (1976). One Good Term Deserves Another: The Advantage of Incumbency in Congressional Elections, Paper Presented to the annual meeting of the American Political Science Association, Chicago.

Cox, G. W. and J. N. Katz (1996). "Why Did the Incumbency Advantage in U.S. House Elections Grow?" American Journal of Political Science 40(2): 478-497.

Dawson, P. A. and J. E. Zinser (1976). "Political Finance and Participation in Congressional Elections." American Academy of Political and Social Science Annals 425: 59-73.

Diermeier, D., H. Eraslan, et al. (2002). "Coalition governments and comparative constitutional design." European Economic Review: 893-907.

Diermeier, D. and A. Merlo (2003). " A Structural Model of Government Formation." Econometrica: 2770.

Drudge, M. W. (2008). ""Pork Barrel" Spending Emerging as Presidential Campaign Issue." from http://iipdigital.usembassy.gov/st/english/article/2008/08/20080801181504lcnirellep0.1261713.html\#a xzz3JGhqqH4S.

Elhorst, J. P. (2010). Matlab Software for Spatial Panels. Spatial Econometrics Association. Chicago.

Erikson, R. S. (1971). "The Advantage of Incumbency in Congressional Elections." Polity 3: 395-405. 
Erikson, R. S. (1972). "Malapportionment, Gerrymandering, and Party Fortunes in Congressional Elections." American Political Science Review 66: 1234-1245.

Erikson, R. S. and T. R. Palfrey (2000). "Equilibria in Campaign Spending Games: Theory and Data." American Political Science Review 94(3): 595-609.

Evans, D. (2004). Greasing the Wheels: Using Pork-Barrel Politics to Build Majority Coalitions in Congress. New York, Cambridge University Press.

Faulk, D. (2002). "Do State Economic Development Incentives Create Jobs? An Analysis of State Employment Tax Credits." National Tax Journal 55(2): 263-280.

Feldman, P. and J. Jondrow (1984). "Congressional elections and local federal spending." American Journal of Political Science 28: 147-163.

Ferejohn, J. A. and K. Krehbiel (1987). "The Budget Process and the Size of the Budget." American Journal of Political Science: 296-320.

Fiorina, M. P. (1977). "The Case of Vanishing Marginals: The Beauracracy Did It." American Political Science Review 7: 177-181.

Florax, R., H. Folmer, et al. (2003). "Specification Searches in Spatial Econometrics: The Relevance of Hendry's Methodology." Regional Science and Urban Economics 33: 557-579.

Frates, C. (2009) Payoffs for states get Harry Reid to 60 votes. Politico

Frisch, S. A. (1998). The Politics of Pork: A Study of Congressional Appropriations Earmarks. New York, Garland Publishing.

Garand, J. C. and D. A. Gross (1984). "Changes in the Vote Margins for Congressional Candidates: A Specification of Historical Trends." $\underline{78(17-30) .}$

Gelman, A. and G. King (1990). "Estimating Incumbency Advantage without Bias." American Journal of Political Science 34(4): 1142-1164.

Glaeser, E., H. D. Kallal, et al. (1992). "Growth in Cities." Journal of Political Economy 100(6): 733-746.

Glaeser, E., J. A. Scheinkman, et al. (1995). Economic growth in a cross-section of cities. Working Paper. Washington DC, National Bureau of Economic Research.

Glantz, S. A., A. I. Abramowitz, et al. (1976). "Elections Outcomes: Whose Money Matters?" Journal of Politics 38: 1033-1038.

Groseclose, T. and J. Snyder, James M. (1996). "Buying Supermajorities." American Political Science Review: 303-315. 
Grossman, G. M. and E. Helpman (1994). "Protection for sale." American Economic Review 84(4): 833850.

Gwartney, J. D. and R. Lawson (1996). Economic Freedom of the World: 1996 Annual Report. Economic Freedom Index, Fraser Institute.

Hayek, F. A. (1937). "Economics and Knowledge." Economica 4: 33-54.

Hayek, F. A. (1973). Volume 1. Rules and Order. Chicago, University of Chicago Press.

Heiner, R. (1983). "The origins of predictable behavior." American Economic Review 73(4): 560-595.

Henderson, J. V., A. Kuncoro, et al. (1995). "Industrial development in cities." Journal of Political

Economy 103(5): 1067-1090.

Hodler, R., S. Loertscher, et al. (2010). "Inefficient policies and incumbency advantage." Journal of Public Economics 94(9-10): 761-767.

Holmes, T. J. (1998). "The effect of state policies on the location of manufacturing: evidence from state borders." Journal of Political Economy 106(4): 667-705.

Inman, R. P. (1988). Federal Assitance and Local Services in the United States: The Evolution of a New Federalist Fiscal Order. Fiscal Federalism: Quantitative Studies. Chicago, University of Chicago Press (for NBER).

Inman, R. P. and M. A. Fitts (1990). "Political institutions and fiscal policy: Evidence from the U.S. historical record." Journal of Law, Economics and Organization 6(SPEC. ISSUE): 79-132.

Jacobson, G. C. (1976). "Practical Consequences of Campaign Finance Reform: An Incumbent Protection Act." 24 (1-32).

Jacobson, G. C. (1978). "The Effects of Campaign Spending in Congressional Elections." The American Political Science Review 72(2): 469-491.

Jacobson, G. C. (1987). "The Marginals Never Vanished: Incumbency and Competition in Elections to the U.S. House of Representatives, 1952-1982." American Journal of Political Science 31: 126-141.

Jacobson, G. C. (1990). The Electoral Origins of Divided Government: Competition in U.S. House Elections, 1946-1988. Boulder CO, Westview Press.

Jakee, K. and S. Turner (2002). "The Welfare State as a Fiscal Commons: Problems of Incentives Versus Problems of Cognition." Public Finance Review 30(6): 481-508.

Karabegović, A., F. McMahon, et al. (2002). Economic Freedom of North America. Vancouver, Fraser Institute, and Dallas: National Center for Policy Analysis.

Keefer, P. and S. Khemani (2009). "When Do Legislators Pass on Pork? The Role of Political Parties in Determinating Legislator Effort." American Political Science Review: 99-112. 
King, G. and A. Gelman (1991). "Systematic Consequences of Incumbency Advantage in U.S. House Elections." American Journal of Political Science 35: 110-138.

Koehler, D. H. (1975). "Legislative Coalition Formation: The Meaning of Minimal Winning Size with Uncertain Participation." American Journal of Political Science 19(1): 27-39.

Krebs, T. B. (2001). "Political Experience and Fundraising in City Council Elections." Social Science Quarterly 82(3): 536-551.

Krehbiel, K. and J. R. Wright (1983). "The Incumbency Effect in Congressional Elections: A Test of Two Explanations." American Journal of Political Science 27: 140-157.

Krieger, G., F. Rodrigues, et al. (1994). Os Donos do Congresso: A farsa na CPI do Orcamento. Sao Paulo, Editora Atica.

Lee, L. F. and J. Yu (2010). "Estimation of spatial autoregressive models with autoregressive and heteroskedastic disturbances." Journal of Econometrics 154: 165-185.

LeSage, J. P. and R. K. Pace (2009). Introduction to Spatial Econometrics. Boca Raton, FL, CRC Press Taylor and Francis Group.

LeSage, J. P. and R. K. Pace (2010). "The Biggest Myth in Spatial Econometrics." Working Paper.

Levitt, S. D. and J. M. Snyder (1997). "The Impact of Federal Spending on House Election Outcomes." Journal of Political Economy: 30-53.

Levitt, S. D. and C. D. Wolfram (1997). "Decomposing the Sources of Incumbency Advanatge in the U.S. House." Legislative Studies Quarterly 22(1): 45-60.

Mayhew, D. (1974). "Congressional Elections: The Case of Vanishing Marginals." Polity 6: 295-317.

Miller, T., K. R. Holmes, et al. (2012). 2012 Index of Economic Freedom. Washington, D.C., The Heritage Foundation.

Milyo, J. (1999). "The Political Economics of Campaign Finance." The Independent Review 3(4): 537-547.

Munnell, A. and L. Cook (1990). "How does public infrastructure affect regional economic performance?" New England Economic Review: 11-33.

Nations, U. (2007). Report on the World Social Situation 2007: The Employment Imperative. New York, United Nations.

Nickell, S. (2003). Employment and Taxes. Munich, CESifo Group Munich.

Niou, E. M. and P. C. Ordeshook (1985). "Universalism in congress." American Journal of Political Science: 246-258. 
Ostrom, E. (1990). Governing the commons: The evolution of institutions for collective actions. New York, Cambridge University Press.

Ostrom, E. (1998). "A behavioral approach to the rational choice theory of collective action: Presidential address." American Political Science Review 92(1): 1-22.

Ostrom, E., R. Gardner, et al. (1994). Rules, games and common pool resources. Ann Arbor, University of Michigan Press.

Ostrom, E. and J. Walker (1997). Neither markets not states: Linking transformation processes in collective action arenas. Perspectives on public choice: A handbook. D. Mueller. Cambridge, UK, Cambridge University Press: 35-72.

Ostrom, E., J. Walker, et al. (1992). "Covenants with and without a sword: Self-governance is possible." American Political Science Review 86(2): 404-417.

Palda, K. S. (1973). "Does Advertising Influence Votes? An Analysis of the 1966 and 1970 Quebec Elections." Canadian Journal of Political Science 6: 638-655.

Palda, K. S. (1975). "The Effect of Expenditure on Political Success." Journal of Law and Economics 18: 745-771.

Paletta, D. (2011). Billions in Bloat Uncovered in Beltway. Wall Street Journal.

Pastine, I. and T. Pastine (2012). "Incumbency advantage and political campaign spending limits." Journal of Public Economics 96(1-2): 20-32.

Payne, M. (2014). Five sad and shocking facts about World Cup corruption in Brazil. The Washington Post.

Perdue, L. (1977). "The Million-Dollar Advantage of Incumbency." Washington Monthly 9: 50-54.

Primo, D. and J. Snyder, James M. (2010). "Party Strength, the Personal Vote, and Government Spending." American Journal of Political Science: 354-370.

Raju, M. (2010) Mitch McConnell reverses; backs earmark ban. $\underline{\text { Politico }}$

Rephann, T. and A. Isserman (1994). "New highways as economic development tools: An evaluation using quasi-experimental matching methods." Regional Science and Urban Economics 24(6): 723-751.

Riker, W. H. (1962). The Theory of Political Coalitions. New Haven, Yale University Press.

Samuels, D. J. (2002). "Pork Barreling is Not Credit Claiming or Advertising: Campaign Finance and the Sources of the Personal Vote in Brazil." The Journal of Politics 64(3): 845-863.

Scovel III, C. L. (2007). Review of Congress Earmarks Within Department of Transportation Funds. Washington DC, Department of Transportation. 
Shepsle, K. A., E. S. Dickson, et al. (2002). "Bargaining in Legislatures with Overlapping Generation of Politicians." Working Paper.

Shepsle, K. A. and B. R. Weingast (1981). "Structure-Induced Equilibrium and Legislative Choice." Public Choice: 503-519.

Simon, H. (1982). Models of bounded rationality. Cambridge, MA, Cambridge University Press.

Simon, H. (1984). "On the behavioral and rational foundation of economic dynamics." Journal of Economic Behavior and Organization 5: 35-55.

Snyder, J., James M. and T. Groseclose (2000). "Estimating Party Influence in Congressional Roll-Call Voting." American Journal of Political Science: 193-211.

Sobel, R. S., C. J. Coyne, et al. (2007). "The Political Economy of FEMA: Did Reorganization Matter?" Journal of Public Finance and Public Choice 17: 49-65.

Stansel, D. B. (2013). "An Economic Freedom Index for U.S. Metropolitan Areas." Journal of Regional Analysis and Policy 43(1): 3-20.

Stein, R. M. and K. N. Bickers (1994). "Congressional Elections and the Pork Barrel." Journal of Politics: 377-399.

Stein, R. M. and K. N. Bickers (1995). Perpetuating the Pork Barrel: Policy Subsystems and American Democracy. Camridge UK, Cambridge University Press.

Stratmann, T. (1995). "Some Talk: Money in Politics. A (partial) review of the literature." Public Choice 124(1-2): 135-156.

Stratmann, T. (2006). "Contribution Limits and the Effectiveness of Campaign Spending." Public Choice 129: $461-474$.

Stratmann, T. (2013). "The Effects of Earmarks on the Likelihood of Relection." European Journal of Political Economy 32: 341-355.

Tiron, R. (2012) Earmark Ban Fails to Stop Lawmaker Requests for Spending. Bloomberg

Uhlaner, C. J. and K. L. Schlozman (1986). "Candidate Gender and Congressional Campaign Receipts." The Journal of Politics 48(1): 30-50.

Vanberg, V. (1994). Rules and choice in economics. New York, Routledge Kegan Paul.

Waste, C. A. G. (2001-2012). Congressional Pig Book.

Weingast, B. R. (1979). "A Rational Choice Perspective on Congressional Norms." American Journal of Political Science: 245-262. 
Weingast, B. R., K. A. Shepsle, et al. (1981). "The Political Economy of Benefits and Costs: A Neoclassical Approach to Distributive Politics." Journal of Political Economy: 6426-6464.

Welch, W. P. (1974). "The Economics of Campaign Funds." Public Choice 20: 83-97.

Welch, W. P. (1976). "The Effectiveness of Expenditures in State Legislative races." American Politics Quarterly 4: 333-356.

Welch, W. P. (1977). "Money and Votes: A Simultaneous Equation Model." Paper presented to Public Choice Society, New Orleans, Louisiana.

Wilhite, A. and J. Theilmann (1987). "Labor PAC contributions and labor legislation: A simultaneous logit approach." Public Choice 53(3): 267-276Mi.

Zavodny, M. (2000). "The effect of minimum wage on employment and hours." Labour Economics 7(6): 729-750. 